\title{
LOS PROMOTORES DE LA ORDEN DEL CÍSTER EN LOS REINOS DE CASTILLA Y LEÓN: FAMILIAS ARISTOCRÁTICAS Y DAMAS NOBLES
}

\author{
CISTERCIAN ORDER'S PROMOTERS \\ IN CASTILE AND LEON KINGDOMS: \\ ARISTOCRATIC FAMILIES AND NOBLE LADIES
}

\author{
RAQUEL ALONSO ÁlVAREZ \\ Universidad de Oviedo ${ }^{1}$
}

\begin{abstract}
Resumen: El objetivo de este artículo es la revisión de los cauces por los que se difundió la Orden del Císter en los reinos de Castilla y León. Para ello, se ha hecho un estudio de sus promotores y de cómo se encuentran los más importantes relacionados con el grupo de los Traba. De este análisis se deduce que la devoción a la nueva orden fue transmitida fundamentalmente a través de las redes familiares aristocráticas. Además, se propone una nueva perspectiva para abordar el conocimiento de los monasterios medievales como conservadores de las memorias familiares y el papel desempeñado por las mujeres nobles castellano-leonesas en este complejo entramado señorial.
\end{abstract}

Palabras clave: Monasterios; Orden del Císter; Traba; Patrocinio aristocrático. Memoria familiar; Poder femenino.

\begin{abstract}
The objective of this paper is the revision of the ways for those the Order of Císter in the Kingdoms of Castile and Leon was spread. With this purpose, a study of its promoters, and how the more important related with the Traba's group are found, has been made. From this analysis it is deduced that the devotion to the new order was transmitted fundamentally through the aristocratic family nets. In adition, a new perspective to approach the knowledge of the medieval monasteries as conservatives of the family memoirs and the paper carried out by the noble women from Castile and Leon in this complex manorial net is proposed.
\end{abstract}

Kewwords: Monasteries; Order of Císter; Traba; Aristocratic patronage; Family memory; Feminine power.

\section{SUMARIO}

I. La introducción de la orden del Císter en España: cronología.- II. Los promotores de la orden del Císter en los reinos de León y Castilla. 1. Fundaciones cistercienses relacionadas con la casa de Traba. 2. Fundaciones cistercienses relacionadas con la casa de Haro. 3. Fundaciones cistercienses relacionadas con los Armengol y Ponce de Cabrera. 4. Fundaciones cistercienses relacionadas con Ponce de Minerva y su familia. 5. Fundaciones cistercienses relacionadas con

${ }^{1}$ Departamento de Historia del Arte y Musicología. Campus de Humanidades. Universidad de Oviedo.

El dibujo del árbol genealógico que acompaña a este trabajo.(pp. 710-711) fue realizado por doña Covadonga Ibáñez a la que deseo expresar mi agradecimiento

Siglas utilizadas: ÅEM = Anuario de Estudios Medievales; ȦHN = Archivo Histórico Nacional; JMH = Journal of Medieval History. 
otras familias aristocráticas. 6. Fundaciones cistercienses relacionadas con los reyes y sus familias.- III. Familias aristocráticas, damas nobles y expansión de la orden del Císter en los reinos de León y Castilla.- IV. Final.

\begin{abstract}
De comite domno Petro nati sunt comes domnus Fernandus et domnus Veremudus Petri, qui fundauerunt monasterium Supperadi et miserunt ibi ordinum Cistercii, et domnus Veremudus fuit ibi in ordinem frater et ibi uitam finiuit (Tumbos del monasterio de Sobrado).
\end{abstract}

El estudio de los orígenes de la orden bernarda en España tropieza con un problema especialmente difícil de resolver: frecuentemente resulta imposible el establecimiento de fechas seguras para las fundaciones o afiliaciones cistercienses En consecuencia, es necesario conformarse en ocasiones con dataciones aproximadas obtenidas muchas veces mediante informes indirectos. No será objeto de este trabajo una nueva revisión de estos asuntos, pero sí se hace necesario iniciarlo con un breve estado de la cuestión, pues para el estudio de la promoción resulta de cierta importancia establecer en qué fechas se fueron instalando los bernardos en las tierras hispánicas, especialmente por lo que se refiere a las casas más tempranas. A continuación nos conformaremos con trazar un sumario panorama cronológico de las fundaciones llevadas cabo en los reinos de León, Castilla, Navarra y Aragón entre los años 1140 y 1160.

\title{
I. LA INTRODUCCIÓN DE LA ORDEN DEL CÍSTER EN ESPAÑA: CRONOLOGÍA
}

El monasterio navarro de Fitero ha sido tradicionalmente considerado el más antiguo de toda la Península Ibérica, situándose su fundación en $1140^{2}$. Ese año, Alfonso VII donaba el lugar de Niéncebas al abad y los monjes que vivían en la ermita de Santa María de Yerga ${ }^{3}$ sin especificar la orden a la que pertenecían en ese momento ni tampoco la que deberían seguir a continuación. En realidad, hasta 1145 no aparece el cenobio adscrito a la observancia cisterciense, estando formada probablemente la comunidad de Yerga al

${ }^{2}$ L. TORRES BALBÁS, Inventaire et classsification des monastères cisterciens espagnols, "Actes du Congrès d'Histoire de l'Art", Paris, 1923-1924, p. 121. M. COCHERIL, L'implantation des abbayes cisterciennes dans la Péninsule Iberique, AEM, I (1964), pp. 230-231. M. C. PALLARES MÉNDEZ, El monasterio de Sobrado: un ejemplo de protagonismo monástico en lá Galicia medieval, La Coruña, 1979, p. 115. G. M. ColOMBÁS, El monasterio de Tulebras, Pamplona, 1987, p. 36. A. MASOLIVER, Los cistercienses en España y, Portugal, En J. LEKAI, "Los Cistercienses. Ideales y realidad", Barcelona, 1987, p. 521 . También acepta esa cronología, si bien con algunas reservas, C. MONTERDE ALBIAC, Colección diplomática del monasterio de Fitero (1140-1210), Zaragoza, 1978, pp. 223-239.

3 "(...) ego Adefonsus Hispanie imperator, una cum uxore mea Berengaria in eternum cum Christo regnare desiderans, grato scilicet animo, spontanea uoluntate pro mea maxime parentumque meorum salute pro peccatorum nostrorum remissione dono iure hereditario Deo et ecclesie beate Marie semper uirginis in monte quem dicunt Erga fundate dompnoque Durando eiusque sociis in ipso loco, et ecclesia Deo regulariter et beate Marie seruientibus, eorumque successoribus, illam uillulam desertam et locum quem dicunt Nezeuas (...)". C. MONTERDE, Colección diplomática, $\mathrm{n}^{\circ} 1$. 
principio por un grupo de anacoretas que, como ocurrió en muchas ocasiones, acabó por adherirse al Císter ${ }^{4}$, quizá entre 1147 y $1148^{5}$. Aunque, basándose en un dudoso documento publicado por L. Dailliez ${ }^{6}$, se haya propuesto recientemente un adelanto de la adscripción al Císter de Fitero a un momento anterior a 1145, quizá $1141^{7}$, el análisis de la fuente, como J. C. Valle señaló, sugiere que ésta fue objeto, por lo menos, de una severa interpolación que le resta crédito ${ }^{8}$.

Valparaíso, uno de los establecimientos más antiguos de los reinos hispánicos, no parece sin embargo que fuera ya cisterciense en 1137, como pretendía L. Torres Balbás ${ }^{9}$. El origen del monasterio debe buscarse en una alberguería dedicada a la atención a los peregrinos que el presbítero zamorano Martín Cid había instalado en Peleas ${ }^{10}$. En 1143, Alfonso VII le otorgó una donación con la condición de que abrazara la disciplina bernarda ${ }^{11}$, y esa es la fecha habitualmente aceptada para la adscripción cisterciense del monasterio ${ }^{12}$.

De igual manera, la temprana cronología de 1140 que M. Cocheril, siguiendo la tradición, proponía, con reservas, eso sí, para Monsalud ${ }^{13}$, se ha retrasado hasta después de $1165^{14}$. Tampoco se acepta actualmente la adscrición al Císter de Oseira en 1140 o $1141^{15}$, ni mucho menos la fecha de $1137^{16}$ propuesta por L. Torres Balbás, situándose su afiliación en un momento posterior a 1148, posiblemente durante la segunda mitad del siglo ${ }^{17}$, y debiendo tenerse en cuenta, además, que la primera referencia explícita a

${ }^{4} \mathrm{~J}$. C. VALLE PÉREZ, La introducción de la Orden del Císter en los reinos de Castilla y León. Estado de la cuestión. "La introducción del Císter en España y Portugal", Burgos, 1991, pp. 145147.

${ }^{5}$ J. C. VALLE, La introducción, pp. 140, 150.

${ }^{6}$ L. DAILlIEZ, Los orígenes de Veruela, "El Císter. Órdenes religiosas zaragozanas", Zaragoza, 1987, pp. 165-176.

${ }^{7} \mathrm{M}$. MELERO MONEO, Reflexiones sobre el monasterio cisterciense de Santa María de Fitero, De Arte, 3 (2004), pp. 12-13.

${ }^{8}$ J. C. VAlle Pérez, Monasterio de Fitero. En I. G. BANGO Torviso (dir.) "Sancho el Mayor y sus herederos. El linaje que europeizó los reinos hispánicos", Pamplona, 2006, vol. II, pp. $817-818$.

${ }^{9}$ L. TORRES, Inventaire, p. 121.

10 J. PÉREZ-EMBID WAMBA, El Císter en Castilla y León. Monacato y dominios rurales (siglos $X I I-X V)$, Salamanca, 1986, pp. 32, 40.

${ }^{11}$ J. PÉREZ-EMBID, El Císter p 32 . A. GARCÍA FLORES, Arquitectura de la orden del Císter en la provincia de Valladolid (1147-1515), Madrid, 2003. Microficha, p. 5. Agradezco al autor las facilidades para la consulta de esta obra. Igualmente, que haya tenido la amabilidad de enriquecer este trabajo con sus opiniones.

${ }^{12} \mathrm{M}$. CoCherIL, L'implantation, p. 234. J. PÉREZ-EMBID, El Císter, pp. 33, 41; A. MASOLIVER, Los cistercienses, p. 521. J. C. VALLE, La introducción, p. 153.

${ }^{13}$ M. COCHERIL, L'implantation, p. 234. 1141 según L. TORRES, Inventaire, p. 121 y A. MASOLIVER, Los cistercienses, p. 521 .

${ }^{14} \mathrm{Ca} .1165$ en opinión de J. PÉREZ-EMBID, El Císter, p. 274.; Hacia 1167 según J. C. VALLE, La introducción, p. 15 y A. GARCÍA, Arquitectura, p. 14.

${ }^{15}$ M. COCHERIL, L'implantation, p. 234. A. MASOLIVER, Los cistercienses, p. 521.

${ }^{16}$ L. TORRES, Inventaire, p. 121.

${ }^{17} \mathrm{~J}$. C. VALle PÉREZ, La arquitectura cisterciense en Galicia. I. La Coruña, 1982, p. 25. J. C. VALlE, La introducción, p. 153. 
la orden bernarda no aparecerá en la documentación hasta los años 90 del siglo XII ${ }^{18}$.

El monasterio de Sacramenia que asoma en los textos a partir de 1141 no parece que fuera en ese momento, como se ha creído ${ }^{19}$, cisterciense. En realidad, el primer indicio que permite suponerlo adscrito a la orden aparece en una donación de 1147 otorgada por el obispo de Segovia Pedro de Agen en la que se indica que los monjes debían procurarse el alimento con su propio trabajo $^{20}$. Una referencia clara al Císter no se encuentra hasta $1179^{21}$, si bien es probable que en Sacramenia ya se observaran las normas bernardas algo antes de 1162, año en que recibe el encargo de fundar una filial en Rute, que poco tiempo más tarde aparece en dependencia cisterciense ${ }^{22}$. Atendiendo a estos datos, resulta difícil que, como ha supuesto J. Pérez-Embid, las donaciones otorgadas al monasterio por Alfonso VII a partir de 1144 tuvieran como objetivo favorecer en Castilla la implantación del Císter ${ }^{23}$.

Según la tradición, el monasterio de Melón habría sido fundado en 1142 por Alfonso VII, en dependencia del Císter desde el principio ${ }^{24}$. Esta adscripción, sin embargo, no aparece de modo explícito hasta $1165^{25}$, si bien parece posible que el cenobio gallego pasara a los monjes blancos hacia 1154$1158^{26}$.

Para Valbuena, hace ya tiempo que la fecha tradicional de $1143^{27}$, más tarde retrasada a ca. $1151^{28}$, se considera producto de un equívoco diplomático, correspondiendo la noticia que relaciona explícitamente el monasterio fundado por Estefanía Armengol con el Císter al año $1153^{29}$.

${ }^{18}$ J.C. VAlle, La arquitectura, p. 95. A. GARCÍA, Arquitectura, p. 8.

${ }^{19}$ L. TORres, Inventaire, p. 121. J. PÉREZ-EMBID. El Císter, p. 40, 272. M. COCHERIL, L'implantation, p. 234, retrasa la fecha al año siguiente. También A. MASOLIVER, Los cistercienses, p. 521. Un resumen de los problemas cronológicos relacionados con la fundación de Sacramenia en E. CABRERA MUNOZ, En torno a la fundación del monasterio de Sacramenia. "En la España medieval", 1 (1980), p. 31-42.

${ }^{20}$ J. C. VAlle, La introducción p. 156, n. 85. E. CASAS CASTElls, Santa María de Sacramenia. En I. BANGO TORVISO (dir.) "Monjes y monasterios. El Císter en el medievo de Castilla y León", Valladolid, 1998, p. 490-491. A. GARCíA, Arquitectura, p. 7.

${ }^{21}$ E. CASAS, Santa María de Sacramenia, p. 490-491. A. GARCíA, Arquitectura, p. 6.

${ }^{22}$ A. GARCía, Arquitectura, p. 7.

${ }^{23}$ J. PÉREZ-EMBID. El Císter, p. 40, 272.

${ }^{24}$ L. TORRES, Inventaire, p. 121. M. COCHERIL, L'implantation, p. 234. A. MASOLIVER, Los cistercienses, p. 521 . M. C. PALLARES, El monasterio de Sobrado, p. 115.

${ }^{25}$ A. García, Arquitectura, p. 11.

${ }^{26}$ J. C. VALLE, La arquitectura, pp. 25, 207. J. C. VALLE PÉREZ, La implantación de la orden del Cister en Galicia y su reflejo monumental durante la Edad Media, "Arte del Císter en Galicia y Portugal", S/1, 1998, p. 6.

${ }^{27}$ L. TORRES, Inventaire, p. 121. M. COCHERIL, L'implantation, p. 234. A. MASOLIVER, Los cistercienses, p. 521.

${ }^{28}$ J. PÉREZ-EMBID, El Císter, p. 276.

${ }^{29} \mathrm{~V}$. A. Álvarez PAlenzuela; M. ReCUero Astray, La fundación de monasterios cistercienses en Castilla. Cuestiones cronológicas e ideologicas, "Hispania Sacra", 36 (74), p 437. En 1143 Estefanía Armengol fundó un monasterio, pero sin indicar a qué orden debia de estar sujeto. Publica y analiza el documento A. GARCÍA, Arquitectura, p. 522-525. 
Problemas semejantes oscurecen la fundación de Meira, monasterio considerado cisterciense a partir de 1142 o $1143^{30}$, cuando esa filiación no se manifiesta documentalmente hasta $1161^{31}$, siendo posible, en todo caso, suponerla efectuada en torno a $1151-1154^{32}$.

Aunque Huerta es considerado cisterciense por la tradición desde 1142 o $1144^{33}$, sabemos que en realidad el monasterio pasó a la familia bernarda en 1151, gracias a la donación realizada por Alfonso VII ut faciatis ibi Ordinem de Cistel $^{34}$. Como se verá más adelante, el Emperador abandonó pronto su fundación, que sobrevivió gracias al ingreso en el establecimiento de Martín de Hinojosa ${ }^{35}$.

En realidad, y según demostrara J. C. Valle Pérez ${ }^{36}$, de entre el conjunto de monasterios cistercienses fundados entre 1140 y 1143 , el que dispone de documentación más antigua que indiscutiblemente lo adscribe a la orden bernarda es el gallego de Sobrado. En efecto, la concesión realizada en 1142 por Fernando Pérez, Sancha González y Urraca Vermúdez se refiere explícitamente al Císter como su beneficiaria ${ }^{37}$. Esa es la fecha fundacional aceptada sin discusión ${ }^{38}$ que, a causa de las dudas que aquejan a las cronologías de los demás establecimientos, lo convierten en el primer cenobio indudablemente perteneciente a la orden en España. Parece que en Sobrado se acomodaron en ese momento monjes borgoñones enviados por Bernardo de Claraval $^{39}$, iniciando de este modo los cistercienses su instalación y difusión en los reinos hispánicos.

Durante los años siguientes, las fundaciones se suceden. Además de las ya citadas, en 1147 se establecieron los bernardos en La Santa Espina, bajo la protección de la infanta Sancha, hermana de Alfonso VII ${ }^{40}$.

Ese mismo año, una comunidad femenina cisterciense se instaló por primera vez en territorio hispánico. El monasterio de Tulebras tuvo su primitivo solar en Campos Boetus, lugar cerca de Tarazona proporcionado por

${ }^{30}$ L. TORRES, Inventaire, p. 121. M. COCHERIL, L'implantation, p. 234. A. MASOLIVER, Los cistercienses, p. 521.

${ }^{31}$ A. GARCÍA, Arquitectura, p. 9.

${ }^{32}$ J. C. VAlle, La arquitectura, pp. 25, 153. A. GARCíA, Arquitectura, p. 9.

${ }^{33}$ M. COCHERIL, L'implantation, p. 234. J. PÉREZ-EMBID, El Císter, p. 272.

${ }^{34}$ A. GARCía, Arquitectura, p. 9.

${ }^{35}$ Vid. infra, n. 291.

${ }^{36}$ Pueden consultarse, para esta cuestión, los siguientes trabajos del autor: J. C. VALLE, La arquitectura, p. 25. Los estudios sobre la implantación de la orden del Císter en España: el caso de Galicia. Situación actual y perspectivas, "El Museo de Pontevedra", XLIII (1989), p. 136.

${ }^{37}$ Vid. infra, n. 107.

${ }^{38}$ L. TORRES Inventaire, p. 121. M. COCHERIL, L'implantation, p. 234. M. C. PALLARES, El monasterio de Sobrado, p. 115. A. GARCÍA, Arquitectura, p. 4.

${ }^{39} \mathrm{~J}$. C. VALLE PÉREZ, Entre la innoyación y el recuerdo: notas sobre la implantación monumental de la Orden del Císter en Galicia (siglos XII-XIV), "Actas. II Congreso Internacional sobre el Císter en Galicia y Portugal”. III. Ourense, 1998, p. 1057.

${ }^{40} \mathrm{~L}$. GARCía CALLES, Doña Sancha hermana del emperador León-Barcelona, 1972, pp. 41, 88. M. COCHERIL, L'implantation p. 234. A. MASOLIVER, Los cistercienses, p. 521 . J. PÉREZ-EMBID. El Císter, p. 39. V. À. ÁlVAREZ; M. RECUERO, La fundación, p. 432 . A. GARCÍA, Arquitectura, p. 7. 
García Ramírez de Navarra ${ }^{41}$. El monarca estuvo casado con Urraca, una hija ilegítima de Alfonso VII y de la dama asturiana Gontrodo Petri. Urraca había sido educada por la infanta Sancha, y se unió en matrimonio al rey de Navarra en 1144, cuando era una niña de sólo once años ${ }^{42}$. Resulta tentador imaginar a la joven reina inspirando a su marido la selección de la orden monástica llamada a acomodarse en las proximidades de Tarazona, y suponer que la preferencia le habría sido inculcada por la infanta Sancha, protectora de la Santa Espina. Como veremos más adelante, sin embargo, esta suposición resulta incierta pues la poderosa hermana de Alfonso VII manifestó un marcado eclecticismo en su política de promoción religiosa, en la que no puede advertirse una preferencia marcada por ninguna orden ${ }^{43}$. Un gusto por la variedad piadosa que probablemente traspasó a su pupila, pues Urraca, retirada en Oviedo tras su temprana viudez, apoyó a su madre en la fundación fontevrista de La Vega, a la vez que otorgaba generosas donaciones a la sede de San Salvador y a los monasterios de San Vicente y San Pelayo, sin que parezca haberse interesado particularmente por los bernardos durante sus años de independencia ovetense ${ }^{44}$.

Mucho más insegura resulta la época en la que el monasterio de Monfero pasó al Císter, pues si bien se cree generalmente tardía, situándose a partir de $1201^{45}$, otros autores son partidarios de adelantarla a ca. $1147^{46}$.

La suposición que hace de Santa María de Rioseco una institución cisterciense en $1148^{47}$ carece de soporte histórico, no apareciendo tal hecho documentado hasta $1170-1171^{48}$.

Resulta insostenible la propuesta que considera al monasterio de $\mathrm{La}$ Oliva, en el reino de Navarra, adscrito al Císter en $1134^{49}$, pues sabemos que el cenobio se pobló con una comunidad bernarda hacia $1150^{50}$, gracias a una donación realizada por Ramón Berenguer IV al abad de Scala-Dei ${ }^{51}$.

\footnotetext{
${ }^{41}$ La comunidad pasó a su emplazamiento definitivo gracias a una donación de Sancho VI de Navarra. G. M. COLOMBÁs, El monasterio, pp. 40-41, 51.

${ }^{42}$ Un completo perfil biográfico de la reina Urraca en F. J. FERNÁNDEZ CONDE, La reina Urraca "la asturiana", "Asturiensia Medievalia", 2 (1975), pp. 65-94.

${ }^{43}$ Vid. infra, n. 299. dama.

${ }^{44}$ F. J. FERNÁNDEZ, La reina Urraca, pp. 80-92 para la protección religiosa ejercida por la

${ }^{45}$ M. COCHeriL, L'implantation, p. 237. A. MASOLIVER, Los cistercienses, p. 522. J. C. VALLE, La arquitectura, p. 25.

${ }^{46}$ L. TORRES, Inventaire, p. 121. A. GARCíA, Arquitectura, p. 7.

${ }^{47}$ M. COCHERIL, L'implantation, p. 235. A. MASOLIVER, Los cistercienses, p. 521. V.-A. Álvarez PALENZUELA Monasterios cistercienses en Castilla (siglos XII-XIII), Universidad de Valladolid, 1978, pp. 122-124.

${ }^{48}$ A. GARCÍA, Arquitectura, p. 15.

${ }^{49}$ M. H. MARín, Monasterio de La Oliva: fundador y fecha fundacional, "Príncipe de Viana", 90 (1963), pp. 41-53.

${ }^{50}$ L. TORRES, Inventaire, p. 121. M. COCHERIL, L'implantation, p. 235. A. MASOLIVER, Los cistercienses, p. 521. G. M. ColOMBÁs, El monasterio, p. 36.

${ }^{51}$ J. C. VALLE, La introducción, pp. 152-153.
} 
Aunque rápidamente suspendido, en el monasterio de Toldanos, perteneciente al grupo de Carracedo, se realizó un intento de adscripción al Císter hacia $1152^{52}$. Los detalles se explicarán más adelante.

La afiliación de Montederramo fue fijada por M. Cocheril en $1153^{53}$, aunque parece que debió producirse entre 1155, año en el que aparece por última vez bajo la advocación de San Juan, y 1163, primera mención del Císter ${ }^{54}$.

Santa María de Bujedo de Juarros es un buen ejemplo de lo difícil que resulta en ocasiones establecer con seguridad el año en que un monasterio se adhiere al Císter. Aunque la fundación efectiva no se produciría hasta años más tarde ${ }^{55}$, sabemos que se hicieron dos intentos frustrados: el primero en $1157^{56}$ y el segundo en $1159^{57}$.

Falta por analizar el complejísimo caso de Moreruela, de cronología discutidísima. L. Torres Balbás lo suponía cisterciense en $1131^{58}$, y tanto M. E. Martín como H. P. Eydoux sólo un año más tarde ${ }^{59}$. En caso de ser acertada esta datación, Moreruela sería, indiscutidamente, el monasterio cisterciense más antiguo de España. Sin embargo, ya M. Cocheril situaba su afiliación en torno a $1158^{60}$, y ésta es la opinión que ha prevalecido, pues ese año se registra la última aparición textual de la dedicación a Santiago. En 1162 la documentación indica explícitamente que el cenobio se encontraba en dependencia bernarda ${ }^{61}$, referencia corroborada por el hallazgo de una inscripción que señala ese año como el del inicio de las obras de la cabecera ${ }^{62}$.

Un análisis independiente requiere el caso portugués, objeto de una reciente revisión que ha intentado convertirlo en la avanzadilla cisterciense de

${ }^{52}$ A. GARCÍA, Arquitectura, p. 31.
${ }^{53}$ M. CoCheriL, L'implantation, p. 235. Le sigue A. MASOLIVER, Los cistercienses, p. 521.
${ }^{54}$ J.C. VAlle, La arquitectura, pp. $25,189$. cistercienses, p. 522. La primera aparición documental se retrasa a 1182. A. GARCÍA, Arquitectura, p. 16.

${ }^{56} \mathrm{~V}$. DE LA CRUZ, La abadía cisterciense de Bujedo de Juarros (ss. XII-XIX). Burgos, 1990, pp. 71-72.

${ }^{57}$ A. GARCíA, Arquitectura, p. 16.

${ }^{58} \mathrm{~L}$. TORRES, Inventaire, p. 121.

${ }^{59}$ M. E. MARTín, La entrada del Císter en España y San Bernardo. "Cistercium", 5 (1953), pp. 159-160. H. P. EYDOUX. L'abbatiale de Moreruela et l'architecture des églises cisterciennes d'Espagne. "Cîteaux in de Nederlanden: mededelingen over het Cisterciënzer leven van de XIIe tot en met XVIIIle eeuw", 1954, p. 174.

${ }^{60} \mathrm{M}$. COCHERIL, L'implantation, p. 236. Le sigue, como es habitual, A. MASOLIVER, Los cistercienses, p. 521. También J. PÉREZ-EMBID. El Cister, p. 33.

${ }^{61} \mathrm{~J}$. C. VALLE, La introducción, p. 136.

${ }^{62} \mathrm{La}$ inscripción, encajada en el muro del absidiolo central, dice así: "E MCC". F. MIGUEL HERNÁNDEZ. Aproximación arqueológica al monasterio de Santa María de Moreruela. "Anuario del Instituto de Estudios Zamoranos "Florián de Ocampo" (1994), pp. 63-64, n. 3. Ei hallazgo, además, dio la razón a J. C Valle Pérez, partidario de situar el inicio de la construcción de la iglesia en torno a 1170, frente a otros investigadores que defendían una cronología posterior. J. C. VALLE PÉREZ. La arquitectura en el reino de León en tiempos de Fernando II y Alfonso IX: Las construcciones de la Orden del Císter. En Actas. Simposio Internacional sobre "O Pórtico da Gloria e a Arte do seu Tempo". Santiago de Compostela, 3-8 Outubro de 1988. A Coruña, 1991, pp. 153-155. 
España. La propuesta ha provocado una apasionada polémica que aquí no haremos más que intentar resumir.

Hasta hace sólo unos pocos años, se aceptaban las fechas de implantación cisterciense propuestas por M. de Oliveira ${ }^{63}$ más tarde revisadas por M. Cocheril ${ }^{64}$. Según el primero, el más antiguo monasterio cisterciense portugués habría sido Tarouca, establecido probablemente en $1144^{65}$. En opinión del historiador francés, la preeminencia le correspondería a Sever, fundado en $1143^{66}$. Les seguirían el fracasado Mouraz (1152) ${ }^{67}$, Alcobaça $(1153 \text { o algo después })^{68}$, Lafões (ca. 1162 $)^{69}$, Aguiar (1170) $)^{70}$ Aguias $(1170)^{71}$ y Salzedas $(1196)^{72}$.

Estas dataciones, todas ellas posteriores a los primeros ejemplos españoles, han sido revisadas por M. A. Fernandes Marques. Veamos de qué modo y con qué argumentos.

La investigadora portuguesa considera que São Joaõ de Tarouca ya se encontraría en dependencia del Císter en $1140^{73}$, año en el que aparece sometido a la orden de san Benito. M. L. Real ${ }^{74}$ acepta esta opinión, mientras que, según J. I. de la Torre, siendo posible tal hecho, resulta sin embargo difícil considerar al cenobio el monasterio cisterciense más antiguo del reino de León ${ }^{75}$. En realidad, la primera referencia explícita a su condición bernarda data de $1144^{76}$, momento en el que sabemos que los monjes servían a Dios secundum ordinem cisterciensium ${ }^{77}$. Así pues, no hay seguridad de que la reforma haya llegado a Tarouca antes de 1143 o $1144^{78}$.

\footnotetext{
${ }^{63} \mathrm{M}$. DE OliveIRA, Origens da Ordem de Cister em Portugal, "Revista Portuguesa de Historia" (1951), pp. 317-353.

${ }^{64} \mathrm{M}$. COCHERIL, L'implantation, passim.

${ }^{65}$ M. DE Oliveira, Origens, pp. 324-330.

${ }^{66} \mathrm{M}$. COCHERIL, L'implantation, p. 234.

${ }^{67}$ M. DE OliveIRA, Origens, p. 331. M. COCHERIL, L'implantation, p. 235.

${ }^{68}$ M. DE OLIVEIRA, Origens, pp. 338-343. M. COCHERIL, L'implantation, p. 231.

${ }^{69}$ Quizá en 1162, en opinión de M. DE OLIVEIRA, Origens, pp. 319-322. Entre 1161 y 1169 según M. COCHERIL, L'implantation, p. 232.

${ }^{70}$ Esta es la cronología propuesta por M. COCHERIL, L'implantation, p. 236. M. DE OLIVEIRA, Origens, pp. 336-337 sugiere, sin asegurarla, una adscripción al Císter en torno a 1150. 337.

${ }^{71}$ M. COCHERIL, L'implantation, p. 236. Antes de 1205 según M. DE OliveIRA, Origens, p.

${ }^{72} \mathrm{M}$. COCHERIL, L'implantation, p. 327. Quizá antes en opinión de M. DE OlIVEIRA, Origens, pp. 332-335.

${ }^{73}$ M. A. Fernandes Marques, A introdução da ordem de Cister em Portugal. "La introducción del Císter" p. 170. Una nueva versión de este trabajo en A introducão da Ordem de Cister em Portugal. "Estudos sobre a ordem de Cister em Portugal”. Lisboa, 1998, pp. 29-73.

${ }^{74}$ M. L. REAL, A construção cisterciense em Portugal durante a Idade Media. "Arte del Císter", pp. 44 y ss.

${ }^{75}$ J.I. DE LA TORRE, Evolução histórica de Cister no Vale do Douro, "Cister no Vale do Douro". S/1, 1999, pp. 79 y 80.

${ }^{76}$ M.L. REAL, A construção, p. 43.

${ }^{77}$ G. J. A. COELHo DiAs, Cister. Irradiação de espiritualidade e cultura, "Cister no Vale do Douro", p. 31.

${ }^{78}$ J. C. VALLE, La arquitectura, p. 25.
} 
Santiago de Sever es otro centro monástico cuya afiliación al Císter se ha intentado adelantar, de $1143^{79}$ a $1141^{80}$ en esta ocasión. Debe tenerse en cuenta, sin embargo, que tal hecho no aparece en la documentación hasta 1145 , y que la transformación se debió probablemente a la influencia de Tarouca ${ }^{81}$.

El caso de Santa Maria de Salzedas parece estar mejor fundamentado. Tradicionalmente fechado en $1196^{82}$, sabemos ahora que Teresa Alfonso, su fundadora, lo donó al Císter en $1157^{83}$

En realidad, todo el razonamiento de M. A. Fernandes descansa sobre la escurridiza figura de João Cirita y la revisión cronológica del establecimiento de S. Cristóvão de Lafões. Su adscripción al Císter se venía situando entre 1161 y $1169^{84}$, correspondiendo la primera referencia documental a este hecho al año $1162^{85}$. Sin embargo, y siguiendo las noticias de Rodrigo de Cunha, un cronista del siglo XVII fiable en opinión de Fernandes, la investigadora considera que en Lafões existía ya una comunidad cisterciense establecida en 1137, año en el que Alfonso Enríquez les concedió carta de coto. El grupo, inicialmente eremítico, estaría dirigido por João Cirita y habría sido reformado por influencia del obispo de Oporto João Peculiar ${ }^{86}$. A partir de esta base de operaciones, Cirita habría extendido la nueva ordenación a Tarouca, Sever, Aguias y Salzedas. Este esquema tropieza con numerosas dificultades. A las documentales ya nos hemos referido. Pero además, la figura de Cirita dista mucho de ser bien conocida, e incluso se ha sugerido que bajo este nombre se aglutinen varias personalidades diferentes ${ }^{87}$. Por otro lado, resulta difícil imaginar a João Peculiar, el otro personaje al que se supone involucrado en la reforma cisterciense portuguesa, interesado por ella cuando parece que sus preferencias piadosas se inclinaban hacia los canónigos regulares de san Agustín, cuyo establecimiento de Coimbra favoreció ${ }^{88}$.

En fin que, así las cosas, bien podemos seguir considerando, siempre a la espera de nuevos hallazgos o interpretaciones, al monasterio de Sobrado como la más antigua fundación documentada de los reinos de León, Castilla y Portugal.

Para terminar, y si bien de interés secundario para los objetivos de este trabajo, no puede abandonarse el capítulo inicial sin una breve referencia

${ }^{79}$ M. COCHERIL, L'implantation, p. 234.

${ }^{80}$ M. A. FERNANDES, A introduçao, p. 177.

${ }^{81}$ R. TEIXEIRA; V. TEIXEIRA; J. I. DE LA TORRE, Cister no Vale do Douro: estudio preliminar. "Actas. II Congreso Internacional" I, p. 211.

${ }^{82}$ M. DE OLIVEIRA, Origens, pp. 332-335. M. COCHERIL, L'implantation, p. 237.

${ }^{83}$ J.I. DE LA TORRE, Evolução, p. 101.

${ }^{84}$ M. DE OliveIRA, Origens, pp. 319-322. M. Cocheril, L'implantation, p. 232.

${ }^{85} \mathrm{M}$. L. REAL, $A$ construção, p. 44.

${ }^{86}$ M. A. FERNANDES, $A$ introdução, pp. 168-170.

${ }^{87}$ J.I. DE LA TORRE, Evolução, pp. 80-82.

${ }^{88} \mathrm{~J}$. I. DE LA TORRE, Evolução, p. 79. 
al establecimiento de los monjes del Císter en las tierras aragonesas y catalanas.

A Veruela se le supone el monasterio más antiguo de la Corona de Aragón ${ }^{89}$, habiendo sido fundado en $1146^{90}$. Efectivamente, ese año Pedro Atarés concedió al abad de Scala-Dei el lugar de Veruela para fundar un monasterio ${ }^{91}$, donación confirmada por Ramón Berenguer IV en $1155^{92}$. El patrocinador era nieto de Sancho Ramírez y bisnieto de Ramiro $\mathrm{I}^{93}$ y fue aspirante al trono, pretensión frustada según recuerda Jiménez de Rada ${ }^{94}$. Tanto la fecha de fundación como la promoción de Pedro Atarés fueron puestos en entredicho por L. Dailliez ${ }^{95}$, que supone falso el documento que refiere estos hechos, al no mencionar explícitamente al Císter ni a la Virgen María, argumentos, por cierto, bien endebles. Daillez, además, cree a Veruela bernardo desde 1145 por obra de García Ramírez, basándose en el documento citado anteriormente ${ }^{96}$ que J. C. Valle encontraba dudoso ${ }^{97}$ y que, supuestamente conservado en un archivo particular, nadie, aparte del propio Dailliez, parece haber visto nunca ${ }^{98}$.

Entre 1151 y $1153^{99}$ se fundó el monasterio de Poblet, por iniciativa de Ramón Berenguer IV apoyado en el linaje de Cervera ${ }^{100}$. Por los mismos años $^{101}$, se establecían los cistercienses en Santes Creus, recibiendo igualmente

${ }^{89}$ G. M. ColombÁs, El monasterio, p. 36.

${ }^{90} \mathrm{M}$. COCHERIL, L'implantation, p. 234. A. MASOLIVER, Los cistercienses, p. 521. J. C. VALLE PÉREZ, Las construcciones de la orden del Císter en los reịnos de Castilla y León: notas para una aproximación a la evolución de sus premisas, "Cistercium", 187 (1991) p. 770. E. GUINOT. El Císter catalá: una mirada de conjunt. En F.'GARCÍA-OLIVER (ed.), El Císter, ideals i realitat d'un ordre monástic. Actes del Simposi Internacional sobre el Cister. Valldigna (12981998), Universitat de Valencia, 2001, p. 135.

${ }^{91}$ J. C. VAlle, La introducción, p. 159. "Ego Petrus Taresa cum matre mea factio hanc cartam donationis et confirmationis vobis, abbati Scalae Dei et monachis eius (...)". J. L. CORRAL LAFUENTE, La fundación del monasterio cisterciense de Veruela. "Cuadernos de Estudios Borjanos", IV (1979), p. 40.

${ }^{92}$ I. MARTíNEZ BuENAGA, La arquitectura cisterciense en Aragón 1150-1350, Zaragoza, 1998, p. 42.

${ }^{93}$ I. MARTÍNEZ, La arquitectura, p. 97.

${ }^{94}$ J. FernÁNDEZ VALVERDE (cura et studio), Roderici Ximenii de Rada. Historia de Rebus Hispanie sive Historia Gothica. Corpus Christianorum. Continuatio Medievalis LXXII. Turnholti, MCMLXXXVII. VI, II. Aunque aquí se citará la versión latina, hay traducción: J. FERNÁNDEZ VALVERDE (introducción, traducción, notas e índices), Rodrigo Jimenez de Rada. Historia de los hechos de España. Madrid, 1989. Recuerda estos acontecimietos G. MARTiN. Noblesse et royauté dans le De Rebus Hispaniae (livres 4 à 9). "Cahiers de linguistique et de civilisation médièvales", 26 (2003), p. 104.

${ }^{95}$ L. DAILliEZ, Los orígenes, pp. 167-169.

${ }^{96}$ Vid. supra, n. 6.

${ }^{97}$ Vid. supra, n. 8.

${ }^{98}$ Como advirtiera I. MARTÍNEZ, La arquitectura, pp. 41-42.

${ }^{99} \mathrm{E}$. GUINOT, El Císter catalá, pp. 132, 135. Antes de 1150 según L. TORRES, Inventaire, p. 121. Ese año en opinión de A. MÁsoliver, Los cistercienses, p. 521.

${ }^{100}$ E. Guinot, El Císter catalá, p. 132.

${ }^{101}$ En 1150 según A. MASOLIVER Los cistercienses, p. 521. Entre 1150 y 1152 para E. GuINOT, El Císter catalá, pp. 132, 135. 
el apoyo del conde de Barcelona, que contó en esta ocasión con la ayuda de la casa de Montcada ${ }^{102}$.

En 1152 se inició el complejo proceso fundacional de Santa María de Rueda. Entre ese año y 1154, la familia Maarcanda, de origen francés, promovió la creación de un monasterio en Salz en dependencia de Gimont. Juncerías, una granja del cenobio creada en 1162, recibió su patrimonio al extinguirse aquél. Para terminar, la comunidad se trasladó a Rueda en 1202, a una propiedad obtenida gracias a una donación de Alfonso II de Aragón confirmada en $1182^{103}$.

Ya para terminar, en 1158 se estableció la primera comunidad de monjas cistercienses de la Corona de Aragón. Ese fue el año de la fundación del monasterio de Santa María de Valldemaria ${ }^{104}$.

De este apresurado recorrido por los orígenes hispánicos de la orden del Císter nos interesan dos aspectos fundamentales que se desarrollarán en los apartados siguientes de este trabajo. En primer lugar, a juzgar por nuestros conocimientos actuales, la iniciativa fundacional corresponde a Galicia. Además, el primer monasterio documentado, Sobrado, no se estableció gracias a la promoción regia, sino a la aristocrática.

\section{LOS PROMOTORES DE LA ORDEN DEL CÍSTER EN LOS REINOS DE LEÓN Y CASTILLA}

Si analizamos detenidamente qué grupos familiares se encuentran detrás de las fundaciones cistercienses, teniendo en cuenta especialmente las más tempranas, advertiremos que la mayoría de los promotores pertenecen a los mismos linajes y que buena parte de ellos se encuentran, además, emparentados con los Traba.

\section{Fundaciones cistercienses relacionadas con la casa de Traba ${ }^{105}$}

Hace ya tiempo, como se vio más arriba, que se considera al monasterio de Sobrado la primera fundación cisterciense emprendida en los reinos occidentales hispánicos ${ }^{106}$, según indica un documento de 1142 otorgado por Fernando Pérez de Traba, su mujer Sancha González de Lara y su sobrina

${ }^{102}$ E. Guinot, El Císter catalá, p. 132.

${ }^{103}$ I. MARTÍNEZ, La arquitectura, pp. 43 y 187.

${ }^{104}$ E. GuINOT, El Císter catalá, p. 135.

${ }^{105}$ Se utilizará esta denominación colectiva por razones de comodidad aunque, como advierten M. C. Pallares y E. Portela, durante los siglos XII y XIII no puede considerarse a los Traba un linaje propiamente dicho, entendido como grupo ligado a un territorio al que domina en sucesión agnática. M. C. PALLARES; E. PORTELA, Aristocracia y sistema de parentesco en la Galicia de los siglos centrales de la Edad Media. El grupo de los Traba, "Hispania. Revista Española de Historia”, 185 (septiembre-diciembre 1993), pp. 823-840.

${ }^{106}$ Vid. supra, n. 36. 
Urraca Vermúdez, que era hija de Vermudo Pérez, todos ellos apoyados por Alfonso VII ${ }^{107}$. Sobrado había pertenecido a los antepasados de Urraca Froilaz, la primera mujer de Pedro Froilaz, el padre de Fernando y Vermudo $^{108}$, pero les había sido arrebatado a los propietarios por Fernando I, probablemente castigando la resistencia a su reconocimiento como rey de León ${ }^{109}$.

En época de la reina Urraca y Alfonso Raimúndez, el que será más tarde Alfonso VII, los Traba recuperarán una privilegiada situación al lado del futuro monarca, convirtiéndose Pedro Froilaz en ayo del entonces infante. Los Traba fueron, en momentos de peligro, los apoyos más importantes de Alfonso, y la familia salió beneficiada lógicamente con el triunfo de la causa del monarca ${ }^{110}$. En ese contexto debe situarse la donación, una devolución, en realidad, otorgada por Urraca y Alfonso a Fernando y Vermudo Pérez de Traba del monasterio de Sobrado, que se hizo efectiva en $1118^{111}$.

A diferencia de otros casos, los fundadores de Sobrado se vincularon estrechamente al centro monástico que protegían. Aunque Vermudo Pérez no aparezca directamente en la donación de 1142, sabemos que él había traspasado a su hija Urraca la porción que la dama entregó a la comunidad ${ }^{112}$, la animó a concederla y que, al final de su vida, el conde se retiró a Sobrado,

\footnotetext{
${ }^{107} 1142$ febrero, 14. "Unde ego comes Fernandus Petri Dei proveniente gratia cuius omnia elementa subsistunt arbitrio uxorque mea Sancia Gundisalvi una cum omnibus liberis meis dono et concedo medietatem integram de monasterio Superaddi, sicut mihi evenit in particione fratrum meorum. Itaque con sobrina mea Urraca Veremudi Deo vota, similiter dat aliam medietatem eiusdem monasterii que ei evenit in particione inter fratres suos ex parte patris suisVermudi Petri, cuius consilio et auctoritate sufulta in presenti facimus escripturam testamenti et cartam firmitatis Deo omnipotenti et beate Marie semper uirgini omnibusque santis Dei et ordini Sancti Benedicti secundum consuetudinem cisterciensum degenti (...) pro remedio animarum nostrarum parentumque nostrorum, seu animarum parentum domini nostri imperatoris Domni Alfonsi, cuius consilio et iussione et fortitudine, hec omnia facta sunt, eo tempore ut amplius permaneat liberum et quietum iure hereditaro possidendum Deo et scripto monasterio et supradicto cisterciensi ordini evo perhenni et seculo". AHN, Clero Sobrado, carp. 526, n. 10 y AHN, Códices 977 B, fol. 8 v. y 9 r. v. Publ. M.C. PALLARES, El monasterio de Sobrado, $\mathrm{n}^{\circ} 18$, pp. 279-300. Una versión desdoblada en el Tumbo de Sobrado. P. LOSCERTALES DE G. DE VALDEAVELlano, Tumbos del

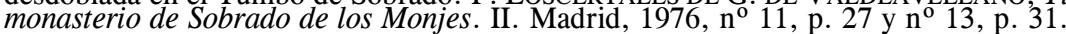

${ }^{108}$ J.L. LÓPEZ SANGIL, La nobleza altomedieval gallega. La familia Froilaz- Traba, A Coruña, 2002 , pp. 37,57 y 82 .

${ }^{109}$ M. C. PALlaRES, El monasterio de Sobrado, $\mathrm{pp}_{\text {. }}$ 108-109. E. PoRTEla SILVA La explicación sociopolitica del éxito cisterciense en Galicia. "En la España Medieval”. III (1982), pp. 320-321. E. PORTELA SILVA, García II de Galicia. El rey y el reino (1065-1090), Burgos, 2001, pp. 21-22.

${ }^{110} \mathrm{M}$. RECUERO ASTRAY, Alfonso VII, emperador. El imperio hispánico en el siglo XII León, 1979, p. 54. B. F. REILLY, The Kingdom of León-Castilla Under King Alfonso VII 1126 1157. Philadelphia, 1998, pp. 17-18. Para el ascenso de la familia, M. C. PALlares; E. PORTELA. Aristocracia, pp. 823-840.

${ }^{111}$ J.C. VALLE, La arquitectura, p. 63. 1118, julio, 29. "Ego Urracha regina Hispanie bone memorie regis domni Adefonsi filia, una cum filio meo Rege Adefonso, comitis Raimundo filio uobis domno Uermudo Petri et fratri uestro Fernando Petri damus monasterium de Superado quod iacet inter Montem Rosum et terram de Sepelunca, quod presit avus meus Fredendus rex et uxor eius Regina domna Sancia de avo uestro Segeredo Alviti et de uxore sua Adosinda Arie violenter sine amni directo et damus supradictum monasterium per hanc scripturam donationis ut cum ulterius habeat hereditario iure. Et hoc facimus pro bono servicio et maxima fidelitate quam nobis semper exhibuisit videntes nos vos iniuste amisisse". AHN, Clero Sobrado, carp. 526, n. 3 y 4 Publ. M.C. PALLARES, El monasterio de Sobrado $\mathrm{n}^{\circ} 17$, pp. 277-278. Una copia, con alguna variante de importancia, en el Tumbo del monasterio. P. LoSCERTALES, Tumbos, II, no 8, p. 23.

${ }^{112}$ J.C. VALLE, La arquitectura, p. 63.
} 
siendo enterrado en el claustro monástico ${ }^{113}$. La familia otorgó frecuentes donaciones al cenobio ${ }^{114}$, conducta no siempre seguida por los fundadores, a menudo rápidamente desinteresados de sus promociones. Sabemos también que varios hijos y nietos de Vermudo se enterraron en el monasterio familiar $^{115}$, o pidieron que su memoria fuera recordada en el Capítulo ${ }^{116}$.

Muy poco tiempo más tarde, hacia $1147^{117}$, se afiliaba al Císter un cenobio fundado anteriormente, Monfero. En 1135, Alonso Vermúdez y Pedro Osorio, con la ayuda de Alfonso VII, habían establecido en ese lugar un monasterio benedictino ${ }^{118}$. Ignoramos si estos personajes, no muy bien conocidos, fueron también los responsables de su adscripción a la orden borgoñona. Aunque no sepamos con seguridad quién fue Alonso Vermúdez, la avalancha de donaciones de miembros de la casa de Traba que recayó sobre Monfero sugiere que pertenecía a la familia ${ }^{119}$. Un personaje de ese nombre aparece en el Memorial de Sobrado, aunque lamentablemente sin indicar filiación ${ }^{120}$. No puede asegurarse que se trate de la misma persona pero parece posible suponerlo. Una de estas donaciones, además, manifiesta de nuevo el extraordinario interés de la casa de Traba por el Císter: en 1147, Lupa Pérez, una de las hijas de Pedro Froilaz, realizó una concesión a Monfero que la dama recuperaría en el caso de que el monasterio abandonara la rigorista orden bernarda ${ }^{121}$. La condición resulta especialmente interesante teniendo en cuenta que a veces los monjes blancos son elegidos sólo como una opción entre varias posibles.

${ }^{113}$ J.L. LÓPEZ, La nobleza, p. 62.

${ }^{114}$ Muchas de ellas, con sus referencias correspondientes, en J.L. LóPEZ, La nobleza, pp. 46$48,60-62,65,70-71,73-75,108,111-112,119,127,134-136,140,145-146,155,157-158$, 161,182 .

${ }^{115}$ Sus hijos Suero y Teresa dispusieron enterramiento en Sobrado. J.L. LóPEZ, La nobleza. pp. 68, 204-205 para el primero y 70 para la segunda. También Rodrigo, Egidio, Enrique y Gil Fernández, hijos de Teresa y su marido Fernando Arias. Ibidem, pp. 71-74.

${ }^{116}$ J.L. LÓPEZ, La nobleza, 74. Sancha Vermúdez, hija de Vermudo Pérez. Igualmente, en 1190, Vẹlasco Fernández, hijo de Toda y sobrino de Fernando y Vermudo: "Preterea mando me sepeliri in monasterio vestro si contigerit me mori in Galletia et vos conceditis mihi pro vestra bona voluntate sepultura in vestro capitulo et partem in orationibus vestris". M. C. PALLARES, El monasterio de Sobrado, p. 222.

${ }^{117}$ Esta es la fecha propuesta por A. García, Arquitectura, p. 7 . J. C. Valle Pérez es partidario de una incorporación mas tardia, que sitúa entre 1201 y 1207 . J.C. VALLE, La arquitectura, pp. 25 y 65.

${ }^{118}$ J.C. VALLE, La arquitectura, p. 65.

${ }^{119}$ Recogidas en J.L. LóPEZ, La nobleza: 1144, Gonzalo Fernández (p. 131); 1145, Vermudo, Fernando y Lupa Pérez (pp. 60,102); 1147, Vermudo, Fernando, Toda y Lupa Pérez (pp. 96, 102); 1149, Elvira Muñiz (p. 109); Gonzalo'Fernández (p. 131); 1150, Vermudo Pérez (p. 50); 1152 , Vermudo Pérez (p. 60); 1157 , Vermudo Pérez y su mujer Urraca (p. 61); 1157, Gonzalo Fernández (p. 132); Lupa Pérez (p. 103); 1159, Gonzalo Fernández (p. 133); 1163, Gonzalo Fernández (p. 133); 1164, Gonzalo Fernández (p. 134); Lupa y Elvira Pérez (p. 103).

${ }^{120}$ J.L. LÓPEZ, La nobleza, p. 188.

${ }^{121}$ J.L. LÓPEZ, La nobleza, pp. 96, 102 y 118. 
Probablemente hacia 1150, Oseira pasó a depender del Císter ${ }^{122}$. En 1137, la heredad de ese nombre había sido entregada por Alfonso VII a una comunidad benedictina a ruegos de Fernando Pérez ${ }^{123}$. No resulta posible asegurar si el caballero ejerció más adelante alguna influencia en la adscripción bernarda.

Igualmente suele relacionarse con Fernando Pérez de Traba, hacia los años veinte del sigo XII, la implantación en Galicia y Portugal de la Orden del Temple, tan estrechamente ligada a Bernardo de Claraval ${ }^{124}$.

En $1175^{125}$ se estableció la comunidad femenina de Ferreira de Pantón, promovida por Fronilde Fernández que la colocó en dependencia de Meira ${ }^{126}$. Tradicionalmente se considera a esta dama perteneciente al grupo de los Traba, hija de Fernando Pérez, hermana por tanto de las fundadoras de Meira y Perales ${ }^{127}$. En opinión de otros autores, la condesa sería hija de Mayor Rodríguez, de la familia gallega Ordóñez , y de Fernando Núñez, y habría estado casada con Rodrigo Pérez, llamado "el Velloso" ${ }^{28}$. Puesto que su marido fue hijo de Pedro Froilaz y hermano de Vermudo y Fernando, queda demostrada la imposibilidad de la primera hipótesis, que haría a doña Fronilde la esposa de su propio tío.

Las iniciativas fundacionales cistercienses de la familia no se agotan en la generación de los hijos de Pedro Froilaz. En una villa desierta donada por Alfonso VII en 1151 a Álvaro Rodríguez de Sarria y a su mujer la infanta Sancha Fernández, se estableció el monasterio de Meira ${ }^{129}$. Aunque la primera mención explícita a la adscripción cisterciense del centro corresponda al año $1161^{130}$, suele considerarse que ésta fue algo anterior, situándose entre 1151 y $1154^{131}$. Sancha Fernández fue fruto de las ilegítimas relaciones habidas entre Fernando Pérez de Traba y la infanta Teresa de Portugal, a su vez hija extramatrimonial de Alfonso VI y Jimena Muñiz ${ }^{132}$.

\footnotetext{
${ }^{122}$ La habitual dificultad para establecer con certeza las afiliaciones cistercienses se advierte especialmente en este caso. Las fechas propuestas van de 1137, según L. TORRES, Inventaire p. 121 , a finales del siglo XII. Para un estado de la cuestión, M.C. PALLARES, El monasterio de Sobrado, p. 115. J. C. VALLE, La arquitectura, pp. 25, 95, 153. A. GARCÍA, Arquitectura, p. 8. La primera referencia documental explícita es de 1199. Vid. supra, n. 15 a 18.

${ }^{123}$ J.C. VAlle, La arquitectura, p. 95. A. GARCíA, Arquitectura, p. 8.

${ }^{124}$ J. FERREIRO ALEMPARTE, Temple, Santo Sepulcro y Císter en su fase inicial gallega. "Actas. II Congreso Internacional" I, pp. 343-344.

${ }^{125}$ J.C. VALLE, La arquitectura, p. 25.

126 “(...) illis Monialibus, quae in Religione sancta uouerint perseuerare, iuxta consuetudinem Cisterciensium monachorum, per manum Abbatis vocati Vitalis de Meyra et conventus sui". Tomado de E. CARRERO SANTAMARÍA Y M. A. GONZÁLEZ GARCÍA, Las dependencias monásticas de San Salvador y Santa María de Ferreira de Pantón (Lugo). Cistercium, 217 (octubre-diciembre 1999), p. 1135 .

${ }^{127}$ Vid. infra. J. C. VAlle, La arquitectura, p. 154. G. CAVERo DOMÍngueZ, El Císter femenino en el reino de León, "Actas. II Congreso Internacional" I, p. 85.

${ }^{128} \mathrm{~J}$. L. LÓPEZ, La nobleza, pp. 111-113. M. TORRES-SEVILLA QUIÑONES DE LEÓN, Linajes nobiliarios en León y Castilla (siglos IX-XIII). Salamanca, 1999, p. 125.

${ }^{129}$ J.C. VAlle, La arquitectura, p. 153. A. GARCíA, Arquitectura, p. 9.

${ }^{130}$ Vid. supra, n. 31.

${ }^{131}$ Vid. supra, n. 32.

${ }^{132}$ G. CAVERo, El Císter femenino, p. 85. J. L. LÓPEZ, La nobleza, p. 134-135.
} 
A pesar de la confusión que rodea su figura, creo que a la misma Sancha, ya en edad avanzada, debe atribuirse la promoción de Moreira, un monasterio femenino establecido en 1183. Considerada en ocasiones hija de la fundadora de Ferreira ${ }^{133}$, fue en realidad sobrina de su marido Rodrigo. También se la ha creído en ocasiones su propia hija ${ }^{134}$. En realidad, parece que no hay duda de que se trata de la hija de Fernando Pérez y de Teresa de Portugal $^{135}$.

Como se verá más adelante, Rodrigo, un hijo de Álvaro y Sancha, quizá casado con María Ponce de Minerva, fue el creador de la orden militar de corte cisterciense de Montegaudio ${ }^{136}$.

El primer centro femenino bernardo de los reinos occidentales fue el de Santa María de la Consolación de Perales, en Palencia, fundado en 1160 por Teresa Fernández, hermana de Sancha, y su primer marido Nuño Pérez de Lara ${ }^{137}$.

Una prima de las dos hermanas fundadoras de Meira y Perales, Guiomar, hija de Rodrigo Pérez y Fronilde ${ }^{138}$, los protectores de Ferreira, se encuentra relacionada con el complejo proceso desarrollado en Montelaturce. En 1162, Pedro Jiménez donó a Pedro, abad en ese momento de Sacramenia, el término de Rute para que se fundara allí un monasterio ${ }^{139}$. Tres años despúes, sabemos que en Rute se observaba la regla de san Bernardo ${ }^{140}$. Más tarde, en 1181, su hermano Diego, que estaba casado con Guiomar Rodríguez, donaba Montelaturce a la Orden del Císter, absorbiendo este cenobio un año después la comunidad de Rute ${ }^{141}$.

En otros casos, la relación con el linaje resulta más dudosa. Mayor García de Aza y su esposo Gonzalo Rodríguez Marañón se encuentran detrás de la fundación de Santa María de Bujedo de Juarros, cenobio cisterciense masculino, y del femenino de Santa María de Aza. Por lo que se refiere al primero, y aunque frustrados por inconvenientes diversos, sabemos que la pareja realizó varios intentos fundacionales a partir de 1157, año en el que se entrevistaron con el abad Bernardo de Gimont (Auch) ${ }^{142}$, encuentro seguido

${ }^{133}$ A. GARCíA, Arquitectura, p. 58.

${ }^{134}$ J.C. VALLE, La arquitectura, p. 154.

${ }^{135}$ J.L. LÓPEZ, La nobleza, passim. M. TORRES-SEVILLA, Linajes, p. 125.

${ }^{136}$ J. M. SÁNCHEZ-Páín, El conde don Rodrigo Álvarez de Sarria, fundador de la orden militar de Montegaudio, "Compostellanum", 28 (1983), pp. 373-393.

${ }^{137}$ J. PÉREZ-EMBID WAMBA, El Císter femenino en Castilla y León. Fundación y organización de las comunidades monásticas (s. XII-XIII), "Actas das II Jornadas luso Espanholas de História Medieval”, III, Porto, 1989, p. 1082.

${ }^{138}$ Vid. supra, n. 128.

${ }^{139}$ A. MASOLIVER, Los cistercienses, p. 521. A. GARcía, Arquitectura, p. 12.

${ }^{140}$ A. GARcía, Arquitectura, p. 7.

${ }^{141}$ Describe el proceso J. DE LEZA, Los López Díaz de Haro, señores de Vizcaya, y los señores de Cameros en el gobierno de La Rioja durante la Edad Media, Logroño, 1954 „pp. 35 36. Leza equivoca sin embargo el nombre de la mujer de Diego Jiménez, a la que llama "Leonor de Trabe", en realidad Guiomar Rodríguez, perteneciente al grupo de los Traba. Para una correcta filiación de la dama, vid. supra, n. 128.

${ }^{142}$ Vid. supra, n. 56 y 57. 
dos años más tarde por una donación al monasterio francés pro abbatia construenda secundum consuetudinem cisterciensis ordinis ${ }^{143}$. Parece que, en realidad, el centro monástico no quedó establecido hasta ca. $1182^{144}$, cuando Mayor García ya era viuda y se encontraba además ocupada con la promoción de Aza, instituto en el que profesó y del que fue abadesa ${ }^{145}$. Algo más difícil resulta establecer satisfactoriamente la procedencia familiar de la pareja. Parece que Gonzalo Rodríguez era de origen navarro, nieto de Pedro Núñez e hijo de Rodrigo Pérez ${ }^{146}$. Fueron los padres de doña Mayor García de Aza y Sancha Pérez. García, a su vez, fue vástago de García Ordóñez de Nájera y, según Rodrigo Jiménez de Rada, de su mujer la condesa Eva ${ }^{147}$. Siguiendo siempre al Toledano, el caballero era más bien de inteligencia limitada y algo tacaño, simplex et rerum non prodigus dispensator, como demostró cediendo la custodia de Alfonso VIII, entonces muy niño, a su medio hermano Manrique Pérez de Lara ${ }^{148}$. Manrique, Álvaro y Nuño Pérez de Lara eran por tanto hijos también de Eva, que estuvo casada dos veces: con Pedro González de Lara ${ }^{149}$ y con García Ordóñez de Nájera. Los dos matrimonios de este último caballero complican aún más la cuestión, pues algunos autores, a pesar del testimonio de don Rodrigo, consideran a García hijo de su segunda esposa Urraca de Navarra ${ }^{150}$. Este problema nos interesa en detalle debido a la tradicional filiación atribuida a la condesa Eva, que suele considerarse hija de Mayor Armengol y de Pedro Fróilaz de Traba, hermana por tanto de Fernando y Vermudo ${ }^{151}$. M. Torres, sin embargo, no cree a Mayor, la segunda mujer de Pedro Froilaz, una Armengol, sino hija de Rodrigo Muñoz, conde de Asturias. Pedro y Mayor, además, no habrían tenido ninguna hija llamada Eva ${ }^{152}$. De todos modos, sabemos que los hermanos Lara de García favorecieron al Císter, así que quizá se haya introducido por esa vía la devoción en la familia. En efecto, Nuño Pérez se encuentra detrás de la fundación de Perales mientras que Arroyo debe posiblemente su existencia a

\footnotetext{
${ }^{143}$ Cit. A. GARCíA, Arquitectura, p. 16.

${ }^{144}$ Cuando se registra la primera referencia al Císter. A. GARCÍ́A, Arquitectura, p. 16. La tradición lo supone activo a partir de 1172. M. CocHERIL, L'implantation, p. 237. A. MASOLIVER, Los cistercienses, p. 522.

${ }^{145} \mathrm{~V}$. DE LA CRUZ, La abadía, p. 78.

${ }^{146}$ Ibidem p. 65. Considera esta filiación sin probar, aunque aceptando su origen navarro, G. MARTÍNEZ Díaz, Orígenes familiares de Santo Domingo, los linajes de Aza y Guzmán. En C: ANIZ IRIARTE; L. V. DÍAZ MARTíN (coord.), Santo Domingo de Caleruega en su contexto sociopolítico, 1170-1221. Jornadas de Estudios medievales, Caleruega, 1992-1993, Salamanca, 1994,

147 “comes Amalricus, comes Aluarus, Nunius Petri de Lara, et hii tres ultimi erant fratres, filii comis Petri de Lara et Aue comitise; Garsias Garsie erat frater eorum ex matre et filius comitis Garsie". J. FERNÁNDEZ (cura et studio). Roderici, VII, XV.

${ }^{148} \mathrm{Ibidem}$. Analiza estos acontecimientos A. RODRÍGUEZ, De rebus Hispaniae frente a la Crónica latina de los reyes de Castilla: virtudes regias y reciprocidad politica en Castilla y León en la primera mitad del siglo XIII, "Cahiers de linguistique et de civilisation hispanique
médievale", 26 (2003), p. 140 .

${ }^{149}$ J.L. LÓPEZ, La nobleza, pp. 44, 114-115.

${ }^{150}$ M. Torres-Sevilla, Linajes, pp. 104, 324.

${ }^{151}$ V. DE LA CRUZ, La abadía, p. 69. J.L. LÓPEZ, La nobleza, pp. 55, 114-115.

${ }^{152}$ M. TorRes-SeVILla, Linajes, pp. 320-325.
} p. 194. 
la intervención de Álvaro. Quizá no sea inútil indicar que el primero estaba casado con una Traba, Teresa Fernández ${ }^{153}$, habiendo enlazado el segundo con Mencía López de Haro, Traba también por parte de madre ${ }^{154}$.

Por último, a Manrique Pérez y a su mujer Ermesenda de Narbona se atribuye el fallido intento fundacional de Arandilla, efectuado en 1167. Su hijo Pedro, señor de Molina, intentará formalizar de nuevo el establecimiento monástico en 1181, sin que éste llegara nunca a materializarse ${ }^{155}$.

Aun más incierta resulta la relación del linaje gallego con los fundadores de Gradefes. Alfonso VII había donado en 1151 la propiedad a García Pérez. En 1168 Teresa Pérez, su viuda, estableció allí una comunidad monástica, pero ignoramos de qué orden ${ }^{156}$. Puesto que don García, muerto ca. 1164 , fue enterrado, siguiendo sus disposiciones, en Sahagún ${ }^{157}$, puede imaginarse que la decisión de fundar Gradefes fuera tomada personalmente por su esposa ${ }^{158}$. La procedencia familiar de los cónyuges resulta poco clara. García era hijo de María Gómez, emparentada con los condes de Carrión y de un noble leonés llamado Pedro Martínez, Flaínez por parte de madre ${ }^{159}$. De Teresa sólo sabemos que tenía un hermano llamado Rodrigo Pérez al que Alfonso VIII donó propiedades en la Alta Sanabria y que era en 1181 lugarteniente de Ponce de Cabrera ${ }^{160}$. Sin poder precisar más los entronques, suele suponérseles una relación familiar con los Traba, pues sabemos que estos tenían propiedades en la zona que en ocasiones entregan a Gradefes ${ }^{61}$. Aldonza González, la fundadora del monasterio de Cañas y una Traba como se verá más adelante, dona al monasterio algunas propiedades en $1171^{162}$.

A Gontroda, hija de García y Teresa, se debe la fundación de Matallana, ca. 1185, en una villa donada a su marido Tello Pérez de Meneses por Alfonso VIII ${ }^{163}$.

Con la misma familia suele relacionarse el establecimiento de Santa Colomba de las Monjas, efectuado en 1181, aunque las opiniones acerca de

${ }^{153}$ Vid. supra, n. 137.

${ }^{154}$ Vid. infra, n. 186.

${ }^{155}$ S. BARTON, The aristocracy in twelfth-century León and Castile, Cambridge University Press, 1997, pp. 84, 105 y 206. A. GARCÎA, Arquitectura, p. 31.

${ }^{156}$ J. PÉREZ-EMBID, El Císter femenino en Castilla y León. Fundación, p. 1083.

${ }^{157}$ J. RODRÍGUEZ, Los fundadores del monasterio de Gradefes, "Archivos leoneses”, 47 y 48 (enero-diciembre 1970), p. 215.

${ }^{158}$ M.J. ALONSO MELCÓN, Relaciones entre el Císter y la nobleza durante los siglos XII-XIII. Un ejemplo leonés, "Cistercium", 207 (1996), p. 930.

${ }^{159}$ S. BARTON, The aristocracy, pp. 37-38.

${ }^{160}$ J. PÉREZ-EMBID, El Císter femenino en Castilla y León. Fundación, p. 1083. J. Canal ha propuesto que Teresa Pérez fuera una Ansúrez hija de Pedro López, si bien advirtiendo sobre la escasa solidez de las pruebas que aduce. "C. CANAL, Doña Teresa Pérez, fundadora del monasterio de Gradefes. Su familia, su vida, "Cistercium", 175 (1988), p. 575.

${ }^{161}$ J. RodRíGUEZ, Los fundadores, p. 217.

${ }^{162}$ J.M. CANAL SÁNCHEZ-PAGín, La casa de Haro en León y Castilla de 1150 a 1250. Cuestiones histórico-genealógicas en torno a cuatro nobles damas, "Archivos leoneses. Revista de estudios y documentación de reinos hispano-occidentales", 85 y 86 (enero-diciembre 1989), p. 60

${ }^{163}$ J. PÉREZ-EMBID, El Císter, pp. 277 y 339. 
la promoción varían entre los que la atribuyen a la propia Teresa Pérez ${ }^{164}$, a sus hermanos, encabezados por Rodrigo ${ }^{165}$, o a unos tales Rodrigo y Vasco ${ }^{166}$, que deben de ser los anteriores.

Podemos terminar este capítulo con el caso, ya tardío y poco significativo por fecharse en un momento en que la orden se encontraba muy difundida, del monasterio femenino de Buenafuente del Sistal. En el año 1234, un cenobio regido por canónigos regulares de san Agustín llegó a manos de Rodrigo Jiménez de Rada que se lo traspasó a la reina Berenguela en 1243. Ésta, a su vez, lo cedió a Alfonso de Molina. A cambio de 4000 maravedís, y a condición de que allí se realizara una fundación cisterciense, el infante lo entregó a su suegra Sancha Gómez ${ }^{167}$, la madre de su primera mujer Mafalda González. Sancha estuvo casada con Gonzalo Pérez de Lara, y era hija de Elvira Pérez y Rodrigo Gómez de Traba ${ }^{168}$. Alfonso Téllez fue marido, además, de Mayor Alfonso ${ }^{169}$, una Meneses que probablemente, como se verá, ejerció una importante influencia en algunas de las devociones practicadas por su hija, María de Molina.

La primera difusión del Císter en Portugal se ha puesto también en relación con la casa de Traba. Como advirtiera J. C. Valle, resulta sospechosa la circulación portuguesa de los miembros de la familia en la época de los establecimientos más tempranos ${ }^{170}$. Los enlaces matrimoniales galaicoportugueses son habituales en estos momentos, por ejemplo, el contraído por Vermudo Pérez y Urraca Enríquez, hermana de Alfonso, el primer rey de Portugal $^{171}$. La frecuencia con la que se documentan miembros de los linajes galaicos en el vecino país ha sido resumida muy expresivamente por $\mathbf{J}$. Mattoso, que señala como a corte estava cheia de galegos. Hasta tal punto estaban relacionados unos y otros que los libros de linajes no suelen diferenciar su procedencia ${ }^{172}$. Pero, como ocurre frecuentemente, más difícil es precisar el papel concreto que desempeñaron los Traba en las fundaciones portuguesas. Algunas conjeturas, sin embargo, pueden hacerse.

Si descartamos, por no probada, la temprana cronología de 1138 atribuida por M. A. Fernandes a Lafões ${ }^{173}$, resulta que el primer monasterio

${ }^{164}$ J. RoDRÍGUEZ, Los fundadores, p. 241.

${ }^{165}$ A. GARCía, Arquitectura, p. 41.

${ }^{166}$ E. CASAs CASTElls, Santa Colomba de las Monjas. En I. BANGo (dir.), "Monjes y monasterios", p. 476.

${ }^{167}$ E. CASAS CASTELLS, Aproximación al estudio de la iglesia del monasterio de Buenafuente del Sistal (Guadalajara): de los canónigos regulares a las monjas cistercienses, "Cistercium", 207 (1996), pp. 752-754.

${ }^{168}$ Nieto de Fernando Pérez de Traba. J.L. LóPEZ, La nobleza, p. 161.

${ }^{169} \mathrm{M}$. TORRES-SEVILLA, Linajes, pp. 231, 338.

${ }^{170}$ J.C. VALLE, Los estudios, pp. 136-137.

${ }^{171}$ M.C. Pallares; E. Portela, Aristocracia, p. 10.

${ }^{172}$ J. MAtToso, A nobreza medieval galaico-portuguesa a identidade e a diferença, "Portugal medieval: novas interpretaçoes", Lisboa, 1985, pp. 174-175.

${ }^{173}$ M.A. Fernandes, A introdução, p. 168. Para los problemas cronológicos del cenobio, vid. supra, n. 84-88. 
cisterciense portugués sería el de Sãn Joaõ de Tarouca, documentado como bernardo por primera vez en $1144^{174}$. Aunque la leyenda atribuya al rey Alfonso Enríquez la iniciativa fundacional, parece que en realidad ésta correspondió a Egas Moniz y su mujer Teresa Alfonso, hija del conde gallego Alfonso Núñez de Celanova ${ }^{175}$. Sabemos que un tal Monio Rodrigues era patrono de un Arouca precisterciense entre 1127 y 1132, y que estaba emparentado con los Traba ${ }^{176}$, y podemos preguntarnos si Monio no habrá sido el padre de Egas. En la siguiente generación, el parentesco entre las dos familias está probado, pues Soeiro Viegas, un hijo de Egas y Teresa, se casó con Sancha Fernández, que era nieta de Vermudo Pérez ${ }^{177}$.

Ya viuda desde hacía más de diez años, Teresa Alfonso fundó en 1157 el monasterio de Salzedas. La dama se encontraba muy próxima a la corona portuguesa, pues se ocupó de la crianza del infante Sancho, primogénito de Alfonso Enríquez ${ }^{178}$.

Además de los promotores pertenecientes a la casa de Traba de manera más o menos próxima o probada, otros linajes que favorecieron a la orden bernarda se encontraban emparentados con la familia.

\section{Fundaciones cistercienses relacionadas con la casa de Haro ${ }^{179}$}

El monasterio femenino de Hayuela, un año más tarde trasladado a Cañas, fue fundado en 1169 por Lope Díaz y su mujer Aldonza ${ }^{180}$. La filiación de don Lope no ofrece mayores problemas, pues sabemos que el caballero pertenecía a una familia vinculada en sus orígenes al señorío de Vizcaya y al Reino de Navarra. Así, Íñigo López, el primer señor de Vizcaya conocido, fue miembro de la corte de García ${ }^{181}$. Tras los dramáticos acontecimientos de Peñalén (1076) y la anexión de La Rioja por parte de Alfonso VI ${ }^{182}$, el Haro se pasó, sin demasiados escrúpulos, al bando leonés. Gracias a estas

${ }^{174}$ Vid. supra. n. 76.

${ }^{175}$ J.I. DE LA TORRE, Evolução, p. 88.

${ }^{176}$ J. MATTOSO, A nobreza medieval galaico-portuguesa, p. 179.

${ }^{177}$ J.L. LÓPEZ, La nobleza, pp. 65 y 74.

${ }^{178}$ J.I. DE LA TORRE, Evolução, pp. 80-82.

${ }^{179}$ Para un panorama de la historia de la casa de Haro, vid. R. Alonso Álvarez, El monasterio cisterciense de Santa María de Cañas (La Rioja). Arquitectura gótica, patrocinio aristocrático y protección real, Logroño, 2004, pp. 26-36.

${ }^{180}$ A. MASOLIVER, Los cistercienses, pp. 545-546.

${ }^{181} \mathrm{~J}$. LuCAS DE LA FuENTE, D. Diego López de Haro V: Magnate de Castilla, señor de Vizcaya y fundador de Bilbao, Bilbao, 1986, p. 41. J.M. CANAL SANCHEZ-PAGÍN, La casa de Haro en León y Castilla durante el siglo XII. Nuevas conclusiones. AEM, 25/1 (1995), p. 4. G. BAURY, Les réligieuses en Castille, XII ${ }^{e}$-XIII ${ }^{2}$ siècles. Ordre cistercien et patronages aristocratiques. Thèse pour obtenir le grade de docteur de l'Université Paris VIII, 1999, voll. II, p. 733. En ultimo término, para estas cuestiones y las que siguen relacionadas con la familia, $\vec{R}$. ALONSO, El monasterio, pp. 27 y ss.

${ }^{182}$ Un análisis de estos hechos y sus consecuencias políticas, en B.F. REILLY, El Reino de León y Castilla bajo el rey Alfonso VI (1065-1109), Toledo, 1989, pp. 107 y ss. 
habilidades políticas, encontramos a su hijo Lope frecuentemente al lado del nuevo monarca ${ }^{183}$.

El nieto y homónimo de Lope Díaz, fundador del monasterio de Cañas, se casó dos veces. No conocemos el nombre de su primera mujer, pero sí sabemos que la segunda se llamaba Aldonza, y que procedía sin duda de una relevante familia gallega. El matrimonio con jóvenes pertenecientes a la aristocracia antigua fue un método frecuentemente utilizado por los recién llegados para afianzar su poder, usado según todas las apariencias por Lope y también por otras importantes figuras como Ponce de Cabrera o Ponce de Minerva ${ }^{184}$. La elegida en este caso fue Aldonza, miembro de los Traba aunque no sabemos con seguridad si por parte de padre o madre. En efecto, J. M. Canal ha propuesto dos posibilidades a este propósito. Según la primera, la muchacha sería hija de Álvaro Rodríguez de Sarria y Sancha Fernández $^{185}$, los fundadores de Meira. Más adelante, y corrigiendo esta opinión, convirtió a Gonzalo Fernández de Traba en su padre ${ }^{186}$, haciéndola nieta por tanto de Fernando Pérez y su legítima mujer Sancha González de Lara $^{187}$. Para nuestro propósito, lo importante es que los Haro se convirtieron a partir de este momento en decididos protectores del Císter, pudiendo advertirse además en su política promotora una llamativa especialización en la rama femenina de la orden que merecerá algún comentario más adelante.

En 1175 o 1176 se fundó otro de los más antiguos monasterios cistercienses femeninos de los reinos occidentales hispánicos, el de Fuencaliente $^{188}$, en Soria. De promoción oscura, es ocasiones ésta se ha atribuido, con pocas garantías, a Urraca de Avellaneda, mujer de Martín López de Haro, se supone que con la colaboración de Pedro Núñez "Príncipe de Osma y señor de Fuente Almejí" ${ }^{189}$. La verdad es que no he podido establecer la identidad de ninguno de ellos. Ningún Martín de la familia Haro, que yo sepa, aparece en la documentación de esa época. Pedro Núñez se encuentra citado en la obra de Rodrigo Jiménez de Rada, pero sin que desgraciadamente el Toledano explique su linaje ${ }^{190}$.

Entre 1181 y 1189 , quedó establecido en Arroyo un nuevo instituto cisterciense femenino dedicado a San Andrés. Su fundadora fue la condesa

${ }^{184}$ S. BARTON, The aristocracy, p. 50.

${ }^{185}$ J.M. CANAL, La casa de Haro en León y Castilla de 1150, pp. 62-63. pp. 10 y ss.

${ }^{86}$ J.M. CANAL SÁNCHEZ-PAGÍn, La casa de Haro en León y Castilla durante el siglo XII,

${ }^{187}$ J.L. LÓPEZ, La nobleza, p. 131.

${ }^{188}$ A. MASOlIVER, Los cistercienses, pp. 545-546. .M. PoZA YAGÜE, Santa María de Fuencaliente. En I. BANGO (dir.), "Monjes y monasterios", pp. 494-495.

${ }^{189}$ C. DE LA CASA; A. RUBIO, El monasterio cisterciense ¿del Sancti Spiritus? Tardesillas (Soria). "Cistercium", 196 (1994), p. 82.

190 “Petrus Nunii de Fonte Almexiri”. J. FERnÁNDEZ (cura et studio), Roderici, VII, XVI. 
Mencía ${ }^{191}$, dama de gran relevancia política que actuó como testamentaria de Alfonso VIII ${ }^{192}$. Tradicionalmente considerada una Lara, A. Canal aclaró hace tiempo su filiación, convirtiéndola en hija de Lope y Aldonza, los fundadores de Cañas. Estuvo probablemente casada con Álvaro Pérez de Lara ${ }^{193}$, así que era cuñada de los fundadores de Perales ${ }^{194}$.

Una hermana de Mencía, Urraca, inició en 1207 los preparativos para una fundación que fue en 1222 entregada a Las Huelgas de Burgos: la del monasterio de monjas de Vileña ${ }^{195}$. Una parte de las propiedades que formaron el dominio inicial le habían sido entregadas por Âlvaro Núñez de Lara ${ }^{196}$, posiblemente su cuñado. Urraca estuvo casada dos veces, la primera con Nuño Melendi, un descendiente de Diego Ansúrez que era primo de Estefanía Ramírez, y la segunda con Fernando II de León ${ }^{197}$.

Una hija de Urraca y Nuño, María, promovió, entre 1240 y 1245, la adscripción al Císter de Otero de Dueñas ${ }^{198}$. Este es otro caso en el que no puede dudarse de la decidida preferencia por la orden bernarda, pues podemos encontrar a María años antes en Cañas, con su abuela Aldonza, más adelante como monja en Carrizo, una fundación de Estefanía Ramírez, prima de su padre, y desde 1207 en Vileña ${ }^{199}$. Sin embargo, fue a Gradefes a donde se dirigió para organizar el establecimiento de Otero, encargándoselo a la abadesa Teresa Alfonso ${ }^{200}$. Un nuevo indicio que refuerza la suposición de un vínculo familiar entre los fundadores de Gradefes y los Haro, quizá a través de los Traba ${ }^{201}$.

El monasterio alavés de Barria, también femenino, aparece documentado por primera vez en 1217 , y sabemos que pertenecía con seguridad al

${ }^{191}$ A. MAsoliver, Los cistercienses, pp. 545-546. J. PÉREZ-EMBID WAMBA, El Císter femenino en Castilla y León. La formación de los dominios (siglos XII-XIII) "En la España medieval V. Estudios en memoria del profesor D. Claudio Sánchez-Albornoz", II, Madrid, 1986, pp. 762-763. A. GARCÍA, Arquitectura, p. 42.

${ }^{192}$ J. PÉREZ-EMBID, El Císter femenino en Castilla y León. Fundación, p. 1086.

${ }^{193}$ J.M. CANAL, La casa de Haro en León y Castilla de 1150, pp. 78-80.

${ }^{194}$ Vid. supra, n. 137.

${ }^{195} \mathrm{~J}$. ÁlVAREZ, Reina y fundadora. Apuntes históricos sobre el monasterio cisterciense de Vileña. Burgos, 1952, p. 173. A. MASOLIVER, Los cistercienses, pp. 545-546. J. PÉREZ-EMBID El Císter femenino en Castilla y León. Fundación, pp. 1080 y 1092 . A. GARCía, Arquitectura, p. 47. A. GARCíA Flores, Santa María la Real de Vileña. En I. BANGo (dir.), "Monjes y monasterios", p. 499.

${ }^{196}$ J. PÉREZ-EMBID, El Císter femenino en Castilla y León. La formación, p. 763.

${ }^{197}$ M.J. Alonso, Relaciones, pp. 924-932.

${ }^{198}$ A. MASOlIVER, Los cistercienses, pp. 545-546. M.V. HERRÁEZ OrTEGA, M. C. COSMEN Alonso, Los promotores del arte cisterciense en León. En VII CEHA. Patronos, Promotores, Clientes y Mecenas. Actas. Mesa I. Murcia, 1992, p. 70. S. Calvo CAPILla, Santa María de Otero de las Dueñas. En En I. BANGO (dir.). "Monjes y monasterios", pp. 488-489.

${ }^{199}$ J.M. CANAL, La casa de Haro en León y Castilla de 1150, p. 78. M.V. HerráEZ, M.C. Cosmen, Los promotores, p. 70. Para la promoción de Carrizo, vid. infra.

${ }^{200}$ M.P. Moreno, Relaciones entre los monasterios cistercienses de Gradefes, Otero de Dueñas y Carrizo, "Archivos leoneses", 49 (enero-junio 1971), p. 131.

${ }^{201}$ Vid. supra, n. 161 y 162. 
Císter en $1232^{202}$. Fue su patrono, y probablemente también el fundador, Lope Díaz II "Cabeza Brava" ${ }^{203}$, nieto de los fundadores de Cañas ${ }^{204}$.

Lope Díaz II se casó con Urraca Alfonso, hermana bastarda de Fernando III, matrimonio del que nacieron el heredero, Diego López IV, y también Alfonso López. Este último, casado con María Alvarez de los Cameros, fue el responsable de la instalación de las monjas bernardas en Herce $^{205}$, entre 1242 y $1246^{206}$. Es importante destacar que Alfonso, a la muerte de su padre, consiguió hacerse con las tenencias riojanas a costa del primogénito ${ }^{207}$, que conservó sin embargo el control del monasterio familiar de Cañas. Muy probablemente a esa razón se deba la fundación de un nuevo centro monástico directamente protegido por el engrandecido segundón.

\section{Fundaciones cistercienses relacionadas con los Armengol y Ponce de Cabrera}

Aunque tradicionalmente se consideraba que el monasterio de Valbuena había sido fundado en $1143^{208}$, sus comienzos cistercienses deben situarse en realidad diez años más tarde, según demostraron V. Álvarez y M. Recuero $^{209}$. Como ha sido advertido, la carta fundacional manifiesta una estrecha relación con los usos monásticos anteriores a la reforma que parece contradecir el espíritu de la orden del Císter ${ }^{210}$. Pero sobre estos problemas se volverá más adelante. En este momento nos interesa el hecho de que en 1153 Alfonso VII y la reina Berenguela entregaron el lugar de Valbuena a la condesa Estefanía ${ }^{211}$. Esta dama era sin duda Estefanía Armengol, que fue hija de Armengol VI y María Pérez. Es frecuente la presencia de magnates orientales al lado de los reyes de León a partir especialmente de Alfonso VI. Este monarca, recuérdese, casado él mismo con varias damas francesas, había unido también a sus hijas con caballeros borgoñones. Del matrimonio celebrado entre Raimundo de Borgoña y la infanta Urraca nació el Emperador. Cuando Alfonso VII se unió a Berenguela, la hija de Ramón Berenguer, ésta llegó a su destino acompañada de Ponce de Cabrera, que se instalará ya

${ }^{202}$ A. GARCíA, Arquitectura, p. 46.

${ }^{203}$ J. ÁlVAREZ, Reina, p. 173.

${ }^{204}$ R. Alonso, El monasterio, p. 32.

${ }^{205}$ J.M. CANAL. La casa de Haro en León y Castilla de 1150, p. 85.

${ }^{206}$ A. GARCía, Arquitectura, p. 52.

${ }^{207}$ M. DiAGO HERNANDO, Los Haro de Cameros en los siglos XIII y XIV. Análisis del proceso de su afianzamiento político en el ámbito regional, AEM, 24 (1994), p. 777.

${ }^{208}$ A. MASOLIVER, Los cistercienses, p. 521.

${ }^{209}$ V.A. ÁlVAREZ; M. RECUERO, La fundación, p. 437. Vid. supra, n. 27, 28 y 29.

${ }^{210}$ Este hecho ha sido notado por J. PÉREZ-EMBID. El Císter, p. 275.

211 "Ego Adefonsus Dei nutu Hyspaniae imperator una cum uxore mea Berengaria hanc comitisse dompne Stephanie suprascriptam donationem ordini sancti benedicti factam recipio et firmam stabilemque permanere precipio". AHN, Clero, carp. 3440, $\mathrm{n}^{\circ} 1$, doc. 1 . Tomado de V. A. AlvAREZ; M. RECUERO, La fundación, p. 436, n. 16. 
definitivamente en la corte leonesa ${ }^{212}$. Los condes de Urgel, con el nombre dinástico de Armengol, aparecen relacionados con los territorios occidentales a partir del IV de ese nombre (m. 1092), al encomendar éste la custodia de su hijo a Alfonso VI. Este niño, convertido en Armengol V, contrajo matrimonio con María, una hija de Pedro Ansúrez perteneciente por tanto a la antigua y poderosa familia Beni Gómez de Carrión ${ }^{213}$. Es muy probable que el enlace se haya decidido respetando los deseos del padre del contrayente ${ }^{214}$. Llegado el caso, el conde Pedro defendió denodadamente los derechos de su nieto, huérfano de pocos años, en el condado de Urgell. Así pues, la fundadora de Valbuena era hermana de este Armengol VI al que sostuvo su abuelo Ansúrez $^{215}$. Cómo llegó esta dama a interesarse por la Orden del Císter resulta un problema de solución difícil, especialmente si tenemos en cuenta la inclinación de los Ansúrez por los también reformados canónigos de Prémontré, fácil de comprender si tenemos en cuenta que su introductor en España pertenecía a la familia. En efecto, un nieto de Pedro Ansúrez, Sancho, junto con Domingo, hijo extramatrimonial de la reina Urraca y de Gómez González de Candespina, trabaron conocimiento con la nueva orden en el curso de un viaje a Francia y la trajeron a España ${ }^{216}$. Domingo fundó el monasterio de Nuestra Señora de La Vid sobre terrenos donados por Alfonso $\mathrm{VII}^{217}$, mientras que Sancho promovió su instalación en Retuerta, apoyado por su primo Armengol VI y por la tía de éste doña Mayor, otra de las hijas de Pedro Ansúrez ${ }^{218}$. Es cierto que Estefanía había estado casada en segundas nupcias con Rodrigo Pérez de Lara, cuya familia hemos visto relacionada con la orden bernarda. Sin embargo, la primera fundación cisterciense vinculada directamente a los Lara fue la de Perales, algunos años posterior a Valbue$\mathrm{na}^{219}$. Debemos recordar, sin embargo, que en el establecimiento de Sobrado, formalizado en 1142, intervino Sancha González de Lara como esposa de Fernando Pérez ${ }^{220}$. Por lo que se refiere al primer marido de la condesa Estefanía, Fernando García de Hita, su procedencia nos resulta absolutamente desconocida, una vez descartada la tesis antigua que lo creía hijo de García de

\footnotetext{
${ }^{212}$ M. RECUERO, Alfonso VII, pp. 144-145. E. FERNÁNDEZ-XESTA Y VÁZQUEZ, Un magnate catalán en la corte de Alfonso VII. Comes Poncius de Cabreira, Princeps Çemora. Madrid, 1991, p. 18 .

${ }^{213}$ J.M. CANAL SÁNCHEZ-PAGín, Casamientos de los condes de Urgell en Castilla. AEM, 9 (1989), , pp. 120-125.

${ }^{214}$ S. BARTON, The Count, the Bishop and the Abbot: Armengol VI of Urgell and the Abbey of Valladolid. "The English Historical Review" 440, CXI (February 1996), p. 89.

${ }^{215}$ J.M. CANAL SÁNCHEZ-PAGín, Casamientos, pp. 120-125.

${ }^{216}$ M.T. LÓPEZ DE GUEREÑO SANZ, Monasterios medievales premostratenses. Reinos de Castilla y León. I. Junta de Castilla y León, 1997, pp. 50, 228.

${ }^{217}$ M.T. LÓPEZ DE GUEREÑO, Monasterios, I, pp. 227-228.

${ }^{218}$ M. T. LÓPEZ DE GUEREÑO, Monasterios, II, p. 555.

${ }^{219}$ Vid, supra, n. 137.

${ }^{220}$ Vid. supra, n. 107.
} 
Galicia y nieto por tanto de Fernando I y la reina Sancha ${ }^{221}$. De igual manera, parece dudoso el hecho de que la dama llamada Mayor que estuvo casada con Pedro Froilaz de Traba fuera una Armengol, como se venía suponiendo ${ }^{222}$. Sin embargo, sabemos que, desde el matrimonio de María Pérez y Armengol V la familia estaba íntimamente unida a los Traba ${ }^{223}$, aunque no podamos estar seguros de si la relación incluía algún enlace matrimonial entre ambos grupos. Otro vínculo posible entre doña Estefanía y los monjes blancos puede establecerse, aunque ha de confesarse que de manera escasamente convincente, a través de su segundo marido Rodrigo González de Lara, que había estado unido anteriormente a la infanta Sancha de León ${ }^{224}$, una hija de Alfonso VI e Isabel de Francia ${ }^{225}$. Fruto del matrimonio celebrado entre Luis VI y Adelaida de Saboya, la princesa Isabel era hermana por tanto de Luis VII, promotor del monasterio cisterciense de Barbeau. El monarca galo adoptó la extraordinaria decisión de ser sepultado en su fundación, despreciando el tradicional y emblemático panteón de los reyes de Francia, la abadía de Saint-Denis ${ }^{226}$. Sólo una especial devoción por los bernardos puede explicar tan sorprendente acto.

Veamos si podemos iluminar este problema analizando otra fundación relacionada con la familia, la de Moreruela, hecha, pese a algunos intentos sin fundamento de atribuirla a Alfonso VII ${ }^{227}$, a iniciativa de Ponce de Cabrera, un primo de Estefanía Armengol. En realidad, el Emperador entregó en 1143 un antiguo monasterio fundado por Alfonso III, en aquel momento deshabitado, a su alférez catalán, con la obligación de restaurarlo pero sin indicar a qué orden debía ser confiado. Será, además, el magnate el encargado de correr con todos los gastos y ocuparse de las gestiones necesarias ${ }^{228}$. Durante mucho tiempo considerado el monasterio cisterciense más antiguo de los reinos de León y Castilla ${ }^{229}$, su adscripción bernarda se sitúa actualmente entre 1158, la última aparición documental bajo la advocación de Santiago, y 1162, la primera mención del Císter ${ }^{230}$. Ponce es uno de esos nobles catalanes llegados a la corte de Alfonso VII en el séquito de Berenguela de Barcelona ${ }^{231}$ pero ya estaba relacionado anteriormente con los Ansúrez, pues era hijo de Guerau II

\footnotetext{
${ }^{221}$ Un resumen de las opiniones tradicionales, con la pertinentes referencias, en M. TORRESSEVIlla, Linajes, pp. 79-80. Descarta esta posibilidad, con convincentes argumentos, E. PORTELA, García II, pp. 38 y ss.

${ }^{222}$ Vid. supra, n. 152.

${ }^{223}$ E. FERNÁNDEZ-XESTA, Un magnate, p. 19.

${ }^{224}$ M. TORRES-SEVILla, Linajes, pp. 219 y ss.

${ }^{225}$ Informa sobre esta filiación Rodrigo Jiménez de Rada. J. FERNÁNDEZ (cura et studio). Roderici, VI, XX. "Hic [Aldefonsus] V $V^{\mathrm{e}}$ uxores successiue legitimo matrimonio (...) quarta Helisabeth, ex qua genuit Sanciam, que fuit uxor comitis Roderici".

${ }^{226}$ A. ERLANDE-BRANDENBURG, Le roi est mort. Étude sur les funérailles, les sépultures et les tombeaux des rois de France jusqu'à la fin du XIII ${ }^{e}$ siècle. Paris, 1975, pp. 87, 161-162. p. 29.

${ }_{22}^{227}$ D. YÁÑEZ NEIRA, Alfonso VII de Castilla y la orden cisterciense, "Cistercium", 61 (1959),

${ }^{228}$ J. PÉREZ-EMBID, El Císter, pp. 30 y 44. E. FERnÁNDEZ-XESTA, Un magnate, p. 103.

${ }^{229}$ Cisterciense desde 1131 según L. TORRES, Inventaire, p. 121.

${ }^{230}$ Para su cronología, Vid. supra, n. 58 a 62.

${ }^{231}$ Vid. supra, n. 212.
} 
Ponç y de Elvira Pérez, otra de las hijas del conde Pedro y hermana de María, la madre de Estefanía Armengol. Era, en consecuencia, primo de la fundadora de Valbuena ${ }^{232}$. Casado dos veces, fue la segunda mujer de Ponce María Fernández de Traba, otra de las hijas de Fernando Pérez y Sancha González de Lara, los fundadores de Sobrado ${ }^{233}$. Sabemos, además, que Ponce y María estaban ya unidos en matrimonio en 1142, año en el que realizan los cónyuges una donación conjunta ${ }^{234}$. Es decir, que una dama de la familia Traba se incorpora al grupo de los Ansúrez-Armengol antes del establecimiento de Valbuena, probablemente la primera fundación cisterciense de estos linajes. Pienso que así puede explicarse razonablemente esta devoción algo anómala en una familia decididamente especializada en la protección de los canónigos de Prémontré. Artífices de la más temprana fundación premostratense de Cataluña, Bellpuig de les Avellanes, promovida por Armengol VII en $1166^{235}$, a Mayor Pérez, otra de las muchas hijas del conde Pedro, apoyada por Armengol VI, se debe el establecimiento de Retuerta ${ }^{236}$, correspondiendo la institución del de Villamediana a María de Almenara, de la que fueron padres Armengol VI y Elvira Rodríguez de Lara ${ }^{237}$.

Por último, debemos referirnos a los fundadores del monasterio de Nogales, que fueron Sancha Ponce y su primo y marido Vela Gutiérrez. Hija la primera de Ponce de Cabrera y María Fernández de Traba, su esposo nació del matrimonio compuesto por Gutierre Vermúdez y Toda Pérez de Traba, otra de las hermanas del Fernando de Sobrado ${ }^{238}$. De nuevo encontramos aquí un establecimiento efectuado en un territorio donado por Alfonso VII. En 1149, el lugar de Nogales había sido entregado por el Emperador a Vela Gutiérrez propter amore servicii quod fecistis mihi multotiens. Al año siguiente, el nuevo propietario y su esposa se lo confiaron a Aldara Pérez, una monja procedente de San Miguel de Bóveda, con la intención de instalar allí una comunidad femenina, pronto desaparecida, regida por la regla de san Benito. En 1164, los dueños acabaron por traspasárselo a Moreruela, el monasterio protegido por el padre de Sancha ${ }^{239}$. Da la impresión, así pues, de que al Císter se acudió como último recurso, quizá con intención de garantizar la estabilidad de un centro que parece encontrar algunas dificultades para su supervivencia.

${ }^{232}$ E. FERNÁNDEZ-XESTA, Un magnate, pp. 34-35.

${ }^{233}$ J.L. LÓPEZ, La nobleza, pp. 126 y ss.

234"Pontius Geraldi Cabrerensis cum uxori mea María Fernández". Tomado de E. FERNÁNDEZ-XESTA, Un magnate, p. 58.

${ }^{235} \mathrm{~F}$. ESPAÑOL BERTRÁN, Els comtes d'Urgell i el seu panteó dinàstic, "El Comtat d'Urgell". Lleida, 1995 , p. 152.

${ }^{236}$ Vid. supra, n. 218.

${ }^{237}$ M.T. LÓPEZ DE GUEREÑo, Monasterios, I, p. 291.

${ }^{238}$ J.L. LÓPEZ, La nobleza, pp. 76 y ss., 111-118 y 126 y ss.

${ }^{239}$ J. PÉREZ-EMBID, El Císter, pp. 31-33, 45-46. 


\section{Fundaciones cistercienses relacionadas con Ponce de Minerva y su familia}

Ponce de Minerva llegó, al igual que su homónimo Cabrera, con el que frecuentemente se le confunde, a las tierras occidentales en el séquito de la reina Berenguela pero, a diferencia del catalán, poco se sabe de su procedencia familiar. Se le ha supuesto, a causa de su patronímico, originario de la región francesa de Minervois, y emparentado con los condes de Toulouse, sin que se hayan podido precisar más los entronques ${ }^{240}$. Muy joven en esa época, se ocupó de su educación la infanta Sancha, hija de la reina Urraca y Raimundo de Borgoña, y hermana en consecuencia de Alfonso VII. Parece probable que, además, la dama se haya encargado de procurar a su pupilo un ventajoso enlace matrimonial negociando su boda con Estefanía Ramírez $^{241}$. Estefanía fue la hija de Ramiro Fróilaz y Elo Álvarez. El padre descendía, por parte de madre, del infante Sancho de Navarra ${ }^{242}$, mientras que doña Elo era nieta de Pedro Ansúrez, como hija de Álvar Pérez y Mayor Pérez $^{243}$. En consecuencia, las dos estefanías, Armengol y Ramírez, eran parientes cercanas.

A la protección de Ponce de Minerva y Estefanía Ramírez se debe un numeroso conjunto de fundaciones cistercienses, aunque a veces el comportamiento de la pareja en este terreno parezca un tanto errático.

En 1142, Alfonso VII dio al magnate francés el lugar de Sandoval para que allí fundara un monasterio, aunque sin exigir que se encomendara a ninguna orden en particular ${ }^{244}$. En 1167, los nuevos propietarios entregaron el lugar a Diego Martínez para que, junto con sus hermanos, vivieran allí sub Regula B. Benedicti secundum constitutionem Cisterciensem ${ }^{245}$. A Diego Martínez se le ha supuesto marido, en aquel momento viudo, de María Ponce, hija de Ponce y Estefanía ${ }^{246}$, aunque sabemos que la dama aún estaba viva en $1176^{247}$. La tradición del monasterio de Carrizo proporciona noticias sobre este enlace, cuestionado sin embargo por J. M. Sánchez Pagín ${ }^{248}$. Según este investigador, María habría estado casada en realidad con Rodrigo Álvarez de Sarria, hijo de los fundadores de Meira y Traba, recuérdese, por parte de

\footnotetext{
${ }^{240} \mathrm{~S}$. BARTON, Two Catalan magnates in the courts of the kings of León-Castile: the careers of Ponce de Cabrera and Ponce de Minerva re-examinated. JMH, 18 (1992), p. 248.

${ }^{241}$ L. GARCíA, Doña Sancha, p. 30.

${ }^{242}$ Ramiro Fróilaz nació de Froila Díaz y Estefanía Sánchez, hija de Constanza y Sancho de Navarra. M. TORRES-SEVILLA, Linajes, pp. 157-166.

${ }^{243}$ M. TORRES-SEVILla, Linajes, p. 347.

${ }^{244}$ J. PÉREZ-EMBID, El Císter, pp. 47-48.

${ }^{245}$ A. GARCía, Arquitectura, p. 14.

${ }^{246}$ Según el Tumbo nuevo de Carrizo. M.P. Moreno, Relaciones, p. 130. La relación supuesta entre Diego García y los Villamayor parece que carece de base documental. G. MARTÍNEZ DÍEZ, El linaje de los Villamayor. En E. CASAS CASTELLS (coord.), Jornadas culturales con motivo del IX centenario de la fundación del Císter: Monasterio de Villamayor de los Montes 1998, 29-30 de mayo de 1998, Burgos, 1997, p. 153.

${ }^{247}$ Vid. infra, n. 266.

${ }^{248}$ J.M. SÁNCHEZ-PAGÍN, El conde, pp. 386-392.
} 
madre ${ }^{249}$. Aunque no pueda tenerse la absoluta certeza de la celebración de este matrimonio, su existencia iluminaría algunos puntos oscuros. Sabemos que la mujer de don Rodrigo se llamaba María y que tomó el hábito del Císter en 1173, año en el que el caballero se separó de ella para fundar la orden, igualmente de corte cisterciense, de Montegaudio. Pues bien, poco más tarde, en 1176, Estefanía Ramírez, madre de María Ponce, estableció a las bernardas en Carrizo, colocando a su hija al frente de la institución como abadesa ${ }^{250}$.

Sea como fuere, creo que todavía no se ha explicado convincentemente el encargo hecho a don Diego, que no parece sentir una especial inclinación por el Císter, como demuestra tanto el abandono del proyecto de Sandoval como la fundación que emprendió en Benevivere algo más tarde, encomendada a los canónigos de san Agustín ${ }^{251}$. Sandoval acabó por ser entregado a La Santa Espina, monasterio protegido por la infanta Sancha ${ }^{252}$ del que dependía después de $1168^{253}$. El establecimiento de estos lazos quedaría explicado igualmente por ese posible enlace entre María Ponce y Rodrigo Álvarez, pues la madre del caballero era hija de Teresa de Portugal, medio hermana de la reina Urraca Alfonso. Así pues, Sancha Fernández de Traba y Sancha Raimúndez eran primas.

Sabemos con certeza que Ponce y Estefanía no se desentendieron de su monasterio, pues en él fueron sepultados los $\operatorname{dos}^{254}$.

La encomienda de Sandoval resulta todavía más inexplicable si tenemos en cuenta el precedente de Palazuelos. El lugar de Valbení había sido entregado a Diego Martínez por Alfonso VIII en 1165 para que restaurara un abandonado monasterio documentado desde 1063. El caballero se deshizo rápidamente del encargo traspasando la donación a Valbuena ut ordo cisterciensis ibidem integrer et illibatus custodiatur et sit abbatia in perpetuum $^{255}$. Si en realidad estuvo casado con María Ponce, Valbuena había sido fundado por una prima de su suegra. Quizá, no queriendo él ocuparse, decidió entregar Valbení a un establecimiento relacionado con su familia. Pero aún sorprende más que, tras este comportamiento, se le haya encargado la organización de un nuevo establecimiento monástico que, como hemos visto más arriba, tampoco satisfizo sus necesidades piadosas. Valbení languideció hasta que Alfonso VIII decidió traspasárselo a Alfonso Téllez. Trasladado a Palazuelos, fue convertido en panteón de la familia Meneses ${ }^{256}$.

\footnotetext{
${ }^{249}$ J.M. SÁNCHEZ-PAGÍN, El conde, pp. 373-393. Vid. supra.

${ }^{250}$ J.M. SÁNCHEZ-PAGÍn, El conde, pp. 373-393.

${ }^{251}$ J. PÉREZ-EMBID, El Císter, pp. 47-48.

${ }^{252}$ Vid. infra, n. 292.

${ }^{253}$ J. PÉREZ-EMBID, El Císter, p. 48. Es preciso tener en cuenta que esta noticia, proporcionada por el Tumbo monástico, no ha encontrado confirmación documental. A. GARCíA, Arquitectura, p. 175-176.

${ }^{254}$ J. PÉREZ-EMBID, El Císter, p. 48. A. GARCÍA FlORES. La iglesia del monasterio de Valbuena, panteón de los señores de Aguilafuente. "Cistercium", 207 (1996), p. 782, n. 9.

${ }^{255}$ J. PÉREZ-EMBID, El Císter, pp. 278-279.

${ }^{256}$ Vid. infra. n. 270.
} 
Quizá escarmentada por todas esas complicaciones, cuando Estefanía Ramírez, en aquel entonces ya viuda, emprendió la fundación de Benavides, en Palencia, originalmente situada en Valverde, lo hizo donando el territorio al ya consolidado monasterio de Sobrado ${ }^{257}$. La razón de la relación establecida con un cenobio protegido por una familia sólo remotamente emparentada con la suya resulta oscura, a no ser que aceptemos la hipótesis del matrimonio de su hija María con Rodrigo Álvarez, Traba por parte de madre. Más fáciles de explicar son las estancias de Urraca López, después fundadora de Vileña, en el monasterio palentino ${ }^{258}$, pues había estado casada en primeras nupcias con Nuño Melendi, primo de Estefanía Ramírez ${ }^{259}$. Tampoco en esta ocasión parece que la fundadora fuera una protectora constante, pues, establecidos los monjes en Valverde en $1176^{260}$, sólo tres años más tarde recibieron una propiedad en Benavides, regalo de Alfonso VIII, a la que se trasladaron inmediatamente ${ }^{261}$. También resultan indicativas las abundantes donaciones recibidas en el siglo XIII de Rodrigo González Girón ${ }^{262}$, cuyo nombre indica un parentesco con los fundadores de La Vega, como se verá.

En el mismo año de 1176 Estefanía Ramírez decidió el establecimiento de una comunidad femenina bernarda en Carrizo ${ }^{263}$, cuya propiedad le venía en parte de su padre y en parte de una cesión hecha por Alfonso VII a Ponce de Minerva para que se la diera en arras a su mujer ${ }^{264}$. La finalidad de la fundación era probablemente procurar acogimiento a su hija y servir de retiro a la condesa viuda que, aunque no llegó a profesar, fue "gobernadora sin título de abadesa" 265 , es decir, señora, un cargo que encontramos frecuentemente en estos centros femeninos ostentado por una dama perteneciente al grupo de los promotores. Sí desempeñó sin embargo el cargo de abadesa su hija María Ponce ${ }^{266}$, ya separada de su marido, y parece además la responsable de tomar las decisiones definitivas, como se desprende del documento de entrega a la Orden del Císter, en el que se especifica quod si ordini Cistelcensium non placuerit abbatiam sanctimonialum in Karrizo construire, sit in potestate prouidentia comitisse domne Marie, filie mee, faciendi ibi abbatiam sub quocunque ordine Deo seruientium sibi placuerit ${ }^{267}$. Las mismas razones familiares que explican las estancias de Urraca López de Haro en Benavides

${ }^{257}$ V.-A. ÁLVAREZ, Monasterios, p. 82.

${ }^{258}$ M.P. MORENO, Relaciones, p. 132.

${ }^{259}$ Vid supra, n. 197.

${ }^{260}$ V.-A. Álvarez, Monasterios, p. 82.

${ }^{261}$ J. PÉREZ-EMBID, El Císter, p. 278.

${ }^{262}$ M. PoZA YAGÜE, Santa María de Benavides. En I. BANGO (dir.), "Monjes y monasterios", p. 477

${ }^{263}$ A. GARCÍA, Arquitectura, p. 41.

${ }^{264}$ M.C. CASADO LOBATO, Colección diplomática del monasterio de Carrizo. I (969-1260).

León, 1983, p. XIII. J. PÉREZ-EMBID, El Císter femenino en Castilla y León. Fundación, p. 1084.

${ }^{265}$ M.P. MORENO, Relaciones, p. 129.

${ }^{266}$ J. PÉREZ-EMBID, El Císter femenino en Castilla y León. Fundación, p. 1085.

${ }^{267} 1176$, septiembre 10. M. C. CASADO, Colección, no 38, p. 43-45. 
sirven para entender la permanencia como monja de su hija María en Carrizo $^{268}$, antes de establecer su propia comunidad de Otero de Dueñas.

\section{Fundaciones cistercienses relacionadas con otras familias aristocráticas}

Muy pocos personajes al margen de estos importantes grupos se decidieron a emprender una fundación cisterciense. La mayor parte de estas iniciativas fueron, además, tardías, correspondientes a una época en la que la orden ya se había difundido extensamente y resultan, por tanto, escasamente significativas para nuestros propósitos. Sin embargo, haremos un breve recorrido por estas últimas empresas con el objeto de completar el mapa aristocrático de la orden del Císter en los reinos de León y Castilla.

Hemos encontrado hace unas páginas a Tello Pérez de Meneses, junto con su mujer Gontroda García, ocupado en el establecimiento de Matallana, ca. 1185 , en una villa donada al caballero por Alfonso VIII ${ }^{269}$. Un hijo de Tello y Gontroda, Alfonso, entregará en 1213 a la comunidad establecida en Valbení la heredad de Palazuelos, a la que se trasladaron bajo su protección ${ }^{270}$. Alfonso Téllez estuvo casado en primeras nupcias con Elvira Ruiz Girón, perteneciente a la familia fundadora de La Vega. Fue su segunda mujer Teresa Sánchez, una de las hijas de Sancho I de Portugal y Dulce de Barcelona ${ }^{271}$, activa promotora cisterciense ella misma como se verá.

Santa María de La Vega fue instituido en 1215 por Rodrigo Rodríguez Girón e Inés Pérez que donaron un importante conjunto de bienes a monjes procedentes de Benavides ${ }^{272}$, ya en ese momento probablemente en poder de la familiaa ${ }^{273}$.

La Vega recibió a lo largo del siglo XIII diversas donaciones de García Fernández de Villamayor ${ }^{24}$, el fundador del monasterio del mismo nombre. Establecido en 1223, en 1228 fue entregado a Las Huelgas de Burgos por el promotor y su mujer, Mayor Arias ${ }^{275}$. El dominio monástico inicial había sido cedido a García por sus propietarios anteriores mediante un precio simbólico. Éstos eran: Gonzalo Ruiz Girón, hermano del fundador de La Vega, y su mujer Marquesa Pérez; Guillén Pérez, marido de María, hermana de los anteriores y Tello, Teresa y Mayor, todos hijos de Elvira Ruiz Girón, que era hermana de Gonzalo, Rodrigo y María, y estaba casada con Alfonso

${ }^{268}$ M.V. HERRÁEZ; M.C. COSMEN, Los promotores, p. 70.

${ }^{269}$ Vid. supra, n. 163.

${ }^{270}$ A. GARCÍA, Arquitectura, p. 550.

${ }^{271}$ C.-J. ARA GIL, Escultura gótica en Valladolid y su provincia, Valladolid, 1977, p. 11. J. PÉREZ-EMBID, El Císter, p. 339. A. GARCÍA, Arquitectura, pp. 13, 558.

${ }^{272}$ J. PÉREZ-EMBID, El Císter, p. 278. A. GARCÍA FloRES, Santa María de La Vega. En I.

BANGO (dir.), "Monjes y monasterios", pp. 493-494. A. GARCía, Arquitectura, p. 21.

${ }^{273}$ Vid. supra, n. 262.

${ }^{274}$ J. PÉREZ-EMBID, El Císter, p. 340, n. 32.

${ }^{275}$ J. PÉREZ-EMBID, El Císter femenino en Castilla y León. Fundación, p. 1080. 
Téllez de Meneses, el refundador de Palazuelos ${ }^{276}$. Palazuelos, La Vega y Villamayor, se encontraban así relacionados familiarmente.

Pero el evidente dominio aristocrático de las fundaciones cistercienses no debe hacernos olvidar el papel de los reyes de León, Castilla y Portugal y de sus familiares más próximos, que fue también de cierta importancia.

\section{Fundaciones cistercienses relacionadas con los reyes y sus familias}

En el año 1140, Alfonso VII, junto con la reina Berenguela, entregaba a Durando, sus sociis y a la iglesia de Santa María de Yerga, pro peccatorum nostrorum remissione, el lugar de Niéncebas ${ }^{277}$, instituto más adelante trasladado a Fitero. Dejando aparte cuestiones cronológicas ya tratadas, en este momento interesa sobre todo destacar que a esta donación el Emperador sólo añadió otras dos más en los años siguientes: la que incluía la serna de Cervera y sus propiedades junto a los baños de Tudején, de 1146, y la que otorgaba a Niéncebas el monasterio de San Bartolomé de Anaguera, fechada en $1148^{278}$. Nada más, diríamos, que algunas concesiones entre las muchas otras destinadas a diversos monasterios, convenientes todas ellas para el sustento del prestigio y la piedad de un príncipe cristiano.

Más directa parece la intervención de Alfonso VII en el paso al Císter de Valparaíso. Hacia 1140, el presbítero zamorano Martín Cid se había instalado junto con unos compañeros en el lugar de Peleas, donde organizaron una alberguería ${ }^{279}$. A este grupo otorgó el monarca una donación en 1143 con la condición de que adoptara la regla cisterciense ${ }^{280}$.

Dudosa resulta la intervención regia en Sacramenia, cenobio favorecido por las donaciones imperiales a partir de $1144^{281}$. Sin embargo, hasta 1147 no encontramos indicio alguno que permita suponer una adscripción cisterciense, y éste limitado a la afirmación de que en ese momento los monjes debían ganarse el sustento con sus propias manos ${ }^{282}$. La primera referencia documental que relaciona claramente a Sacramenia con la orden bernarda no es anterior a $1179^{283}$, aunque probablemente ya estaba en dependecia del Císter a partir de ca. 1162, año en el que Pedro de Sacramenia recibió el encargo de fundar el monasterio de Rute, que tres años más tarde

${ }^{276} \mathrm{G}$. MARTíNEZ, El linaje, passim.

${ }^{277}$ Vid. supra, n. 3.

${ }^{278} \mathrm{C}$. MONTERDE, Colección diplomática, $\mathrm{n}^{\circ} 7$ y 13 , respectivamente.

${ }^{279}$ J. PÉREZ-EMBID, El Císter, pp. 32, 40.

280، (...) pro Dei amore et remedio pecatorum meorum et ut vita nostra et succesorum nostrorum cum Dei adiutorio et matris suae virginis Mariae valeat melius prosperari, et devotione quam habeo erga Martinum Cidis, quem inveni virum iustum et sanctum, et gratia et devotione quam habeo erga confratres suos et monachos ordinis cisterciensis, qui cum eo sunt in conventu in alberqueria nova de Peleis, circa eclesiam Sancti Michaelis Archangeli". Tomado de J. PÉREZEMBID, El Císter, p. 32.

${ }^{281}$ J. PÉREZ-EMBID, El Císter, pp. 40, 272.

${ }^{282}$ En una donación de Pedro de Agen, obispo de Segovia. Vid. supra, n. 17.

${ }^{283}$ Vid. supra, n. 20. 
aparece bajo la orden de san Bernardo ${ }^{284}$. En todo caso, después de la muerte de Alfonso VII, fallecido en 1157.

Con Santa María de Rioseco sucede algo semejante. Sabemos que allí existía en 1139 una comunidad eremítica ${ }^{285}$ favorecida por Alfonso VII ${ }^{286}$. En estos momentos, parece lo más probable que el grupo no estuviera regido por ninguna regla ${ }^{287}$, sin que haya tampoco motivo para suponerlo adscrito al Císter hacia 1148, como se ha supuesto ${ }^{288}$. En realidad, el instituto no fue con seguridad cisterciense hasta 1170 o $1171^{289}$, muerto el Emperador hacía ya catorce años.

El caso de Santa María de Huerta es diferente. Alfonso VII promovió en 1151 la instalación en el lugar de Cántavos de un grupo de monjes con la condición explícita de que se rigieran por las constituciones cistercienses ${ }^{290}$. Sin embargo, el monarca se desentendió pronto de su sustento y el monasterio sólo superó sus problemas económicos gracias a la protección ejercida por particulares y, especialmente, a partir de la profesión de Martín de Hinojosa, un rico caballero más tarde abad de Huerta que estaba emparentado con Rodrigo Jiménez de Rada ${ }^{291}$.

Muy interesante resulta igualmente el análisis de la protección ejercida sobre el Císter por Sancha Raimúndez, hija de Urraca y Raimundo de Borgoña, y hermana en consecuencia de Alfonso VII. Entre 1143 y 1147, la infanta Sancha fundó el monasterio de Santa María de la Santa Espina, donando el territorio monástico a Clairvaux para que in honore Domini nostri Jesu Christi eiusdemque monasterium edificetis ${ }^{292}$.

Estrictamente, aquí empieza y termina toda la acción fundadora cisterciense de la infanta, aunque será necesario algún análisis complementario para comprender su posición en este terreno. El antiguo oratorio de Santa Marina de Carracedo había sido restaurado por Vermudo II para convertirlo en el lugar de su sepultura ${ }^{293}$. Andando el tiempo llegó a manos de doña Sancha, que lo reactivó donándoselo al abad Florencio y su comunidad, hasta ese momento alojados en Valverde ${ }^{294}$. A partir de ese momento, se desarrollaron formas de vida próximas a las normas bernardas ${ }^{295}$, que en ocasiones se

${ }^{284}$ Vid. supra, n. 21.

${ }^{285}$ A. GARCÍA, Arquitectura, p. 15.

${ }^{286}$ J. PÉREZ-EMBID, El Císter, p. 273.

${ }^{287}$ V.-A. Álvarez, Monasterios, p. 122.

${ }^{288}$ A. MASOlIVER, Los cistercienses, p. 521. V.-A. ÁlVAREZ. Monasterios, pp. 123-124.

${ }^{289}$ A. GARCía, Arquitectura, p. 15.

${ }^{290}$ Vid. supra, n. 34.

${ }^{291}$ J. PÉREZ-EMBID, El Císter, pp. 273, 340-342. J. FERNÁNDEZ (introducción, traducción, notas e índices). Rodrigo, p. 16.

${ }^{292}$ A. MASOlIVer, Los cistercienses, p. 39. L. García, Doña Sancha, p. 41. J. PÉREZ-EMBID, El Císter, p. 39. V.A. AlVAREZ; M. RECUERO, La fundación, p. 432. A'. GARCíA, Arquitectura, p. 7 .

${ }^{293}$ J. PÉREZ-EMBID, El Císter, p. 31.

${ }^{294}$ L. GARCÍA, Doña Sancha, p. 91.

${ }^{295}$ M. COCHERIL, L'implantation, pp. 223, 238-239. 
han querido atribuir a una influencia directa del Císter todavía no formalizada en ese momento ${ }^{296}$. La cercanía de ambos presupuestos aparece explícitamente en el documento pontificio expedido por Inocencio III en 1203 mediante el que Carracedo quedaba en dependencia de Cîteax. Según él, ordo vester $a b$ ordini cisterciensi distaret in paucis ${ }^{297}$. Pero, como advirtiera Pérez-Embid, el hecho de que en el Bierzo se desarrollara, desde mediados del siglo XII, un monacato de sesgo eremítico y estricta observancia, semejante a la practicada por los bernardos, no implica que se siguieran sus usos ni tampoco que se colocara en dependencia del centro borgoñón ${ }^{298}$. En realidad, aquí se manifiesta el acusado eclecticismo piadoso practicado por Sancha Raimúndez, muy semejante, da la impresión, al comportamiento de su hermano, y que analizó L. García Calles ${ }^{299}$. Artífice de la instalación de los canónigos en San Isidoro de León, y protectora decidida del regio instituto, íntimamente vinculado a las infantas célibes, inspiradora probable del paso del cenobio leonés del Valle de Cea a Fontevrault, doña Sancha favoreció también con sus donaciones al monasterio de Sahagún, tan querido por su abuelo, o a los ovetenses de San Pelayo y San Vicente ${ }^{300}$. Esta indecisión generó algún problema de jurisdicción ${ }^{301}$ del que nos ocuparemos enseguida. Todo ello, además del carácter legendario, demostrado ya hace tiempo, del supuesto encuentro con san Bernardo celebrado a la vuelta de una peregrinación a Jerusalén que la infanta nunca realizó ${ }^{302}$, debilita la creencia en una preferencia por el Císter claramente desmentida por los hechos. Pero, sobre todo, creo que es un argumento más sencillo y definitivo el que puede invocarse en último lugar: resulta difícil comprender, si la dama deseaba que en Carracedo se siguiera la observancia cisterciense, por qué razón no colocó al monasterio en dependecia de un cenobio de la orden, cosa que estaba en su poder e hizo algo después en el caso de La Santa Espina, siguiendo así una conducta que hubiera ahorrado multitud de problemas posteriores garantizando además el respeto de sus deseos.

Este mismo contexto explica la situación del monasterio femenino de San Miguel de Dueñas, restaurado en 1152 por la infanta Sancha en dependencia de Carracedo ${ }^{303}$, y que pasará al Císter ca. 1200 junto con la casa

\footnotetext{
${ }^{296}$ Esa es la posición defendida, especialmente, por A. QUINTANA PRIETO, La reforma del Císter en el Bierzo, "Archivos leoneses", XXV (19ł1), pp. 75-101.

${ }^{297}$ A. QUinTANA, La reforma, p. 91.

${ }^{298}$ J. PÉREZ-EMBID, El Císter, p. 50.

${ }^{299}$ L. GARCÍA, Doña Sancha, passim.

${ }^{300}$ L. GARCÍA, Doña Sancha, pp. 79-88, 94, 96-98, especialmente.

${ }^{301}$ G. CAVERO DOMÍNGUEZ; M. A. GONZÁLEZ GARCÍA, El monasterio cisterciense de San Miguel de Dueñas, León, 2000, p. 33.

${ }^{302}$ L. GARCÍA, Doña Sancha, pp. 59-60.

${ }^{303}$ L. García, Doña Sancha, p. 101. J. PÉrez-EMBID, El Císter, p. 51. M.V. HerrÁEz; M.C. COSMEN, Los promotores, p. 68. G. CAVERO; M. A. GONZÁLEZ, El monasterio, pp. 32-34.
} 
madre y el resto de los centros dependientes de ésta: Castañeda, Penamayor, Villanueva de Oscos, Belmonte de Miranda y San Guillermo de Villabuena ${ }^{304}$.

Para terminar con este asunto, es preciso referirse a los problemas ocurridos en el monasterio de Toldanos. Fue fundado por la infanta Elvira Alfonso $^{305}$, fruto de una de las muchas relaciones extramatrimoniales mantenidas por Alfonso VI, en esta ocasión con Jimena Muñiz, madre también de Teresa de Portugal ${ }^{306}$. Parece que fue doña Elvira quien se ocupó de la educación de su sobrina Sancha Raimúndez ${ }^{307}$, a pesar de lo cual sus respectivas fundaciones acabarán por enfrentarse. Como se ha dicho, Elvira Alfonso promovió el cenobio de Toldanos, poblándolo con un grupo de monjes procedentes de Carracedo. Inicialmente, se reconoció sin problemas la supremacía de la casa madre pero, a la muerte del abad Florencio de Carracedo, Toldanos se declaró en rebeldía poniéndose en dependencia de Clairvaux. Doña Sancha protestó enérgicamente, de modo que Bernardo de Claraval acabó por intervenir, rogando a la infanta que transigiera para no perjudicar la fundación de Elvira ${ }^{308}$. En realidad, Toldanos desató los lazos que le unían a Carracedo sin anudar nunca otros demasiado estrechos con Clairvaux, y acabó por someterse a los benedictinos de San Claudio de León $^{309}$, pero nos interesan muy especialmente estos acontecimientos en los que se manifiesta una faceta escasamente amable de las relaciones mantenidas entre Sancha y Bernardo, de las que poco más conocemos.

Alfonso VIII está relacionado con la implantación de algunos centros cistercienses, aunque en algunos casos los argumentos aducidos para demostrarlo no sean demasiado sólidos. Así, por ejemplo, se le considera el fundador de Herrera, afiliado al Císter en 1171, simplemente porque el monarca otorga al cenobio una serie de donaciones ${ }^{310}$. Por lo que se refiere a Bonaval, bernardo desde 1175 , el vínculo propuesto no tiene otra base que la tradición $^{311}$.

Sí puede advertirse, sin embargo, un indiscutible impulso monárquico en el paso al Císter de la comunidad femenina de San Clemente de Toledo,

\footnotetext{
${ }^{304}$ A. QUINTANA, La reforma, p. 75. La adscripción de estos cenobios al Císter fue incluso más tardía, según argumenta A. GARCí, Arquitectura, p. 23-26.

${ }^{305}$ R. TeIXEIRA; V. TeIXEIRA; J.I. DE LA TORRE, Cister no Vale, p. 216.

${ }^{306}$ Casada primero con Enrique de Borgoña y más tarde amancebada con Fernando Pérez de Traba. Vid. supra, n. 132.

${ }^{307}$ G. CAVERO; M. A. GonZÁLEZ, El monasterio, p. 32.

${ }^{308}$ L. GARCÍA, Doña Sancha, pp. 92-93.

${ }^{309}$ S. CALVo CAPILla, Santa María de Toldanos. En I. BANGO (dir.), “Monjes y monasterios", p. 492.

${ }^{310}$ A. MASOLIVER, Los cistercienses, p. 522. V.-A. ÁlvAREZ, Monasterios, p. 100. J. PÉREZEMBID, El Císter, p. 279. A. GARCÍA FLORES, Santa María de Herrera. En I. BANGO (dir.), "Monjes y monasterios", pp. 481-482. A. GARCíA, Arquitectura, p. 16.

${ }^{311}$ A. MASOLIVER, Los cistercienses, p. 521. V.-A. ÁlVAREZ, Monasterios, pp. 85-86. J. PÉreZ-EMmid, El Císter, p. 273. A. GARCÍA, Arquitectura, pp. 17-18.
} 
que se produjo en $1175^{312}$, y una intervención directa tanto en el establecimiento de Óvila, ca. $1181^{313}$, como en la adscripción a Cîteaux de Gumiel de Hizán, en $1194^{314}$.

Pero, indiscutiblemente, el centro cisterciense más cercana y generosamente protegido por el monarca fue el monasterio de Santa María la Real de Las Huelgas de Burgos, cuyo dominio monástico concedió Alfonso VIII en 1187. Aunque en la decisión ejerció una influencia decisiva la reina Leonor, como ya advirtiera Rodrigo Jiménez de Rada ${ }^{315}$, no debió resultar tampoco ajeno al establecimiento el deseo de emular y superar a las fundaciones aristocráticas ${ }^{316}$. Nos detendremos en el problema al desarrollar el tercer apartado de este trabajo.

A pesar de la generosa dotación de Las Huelgas, el exclusivo establecimiento burgalés señala los últimos momentos de esplendor de la Orden del Císter. En época de Alfonso IX no se registra otra fundación que la de Valdediós, en Asturias, formalizada ca. 1200 en dependencia de Sobrado $^{317}$. La relación que establece la tradición entre Fernando III y la de San Clemente de Sevilla, en 1248 o 1249, carece de base documental ${ }^{318}$. Exactamente lo mismo ocurre en el caso de Santa María de las Dueñas de Sevilla $^{319}$. Tampoco puede encontrarse soporte firme para la atribución de Contodo a Alfonso $\mathrm{X}^{320}$ y si sabemos con certeza que el sabio monarca fue el promotor de la instalación de monjas cistercienses en San Clemente de Córdoba, no es menos cierto que el cenobio fue rápidamente abandonado ${ }^{321}$, quizás a falta de una financiación estable.

Esta decadencia convierte en particularmente interesante la decisión adoptada por María de Molina, que fundó el monasterio cisterciense de Las Huelgas de Valladolid en 1320 y dispuso allí su enterramiento ${ }^{322}$. La elección resulta sorprendente si tenemos en cuenta la evidente predilección que la reina

\footnotetext{
312 "Mando etiam quod idem monasterium Sancti Clementis et moniales ibidem Domino sirvientes vivant sub regula Sancti Benedicti et sub habitu et regularibus observantiis cisterciensis (...)". J.C. VIZUETE MENDOZA, El Císter en Toledo. Fundacion y exención del monasterio de San Clemente, "Cistercium", 192 (1993), p. 159.

${ }^{313}$ J. PÉREZ-EMBID, El Císter, p. 275. A. GARCÍA, Arquitectura, p. 31.

${ }^{314}$ A. MASOlIVEr Los cistercienses, p. 522. V.-A. Álvarez, Monasterios, p. 99. J. PÉrezEMBID, El Císter, p. 280. M. POZA YAGÚ, San Pedro de Gumiel. En I. BANGo (dir.). "Monjes y monasterios", p. 474. A. GARCÍA, Arquitectura, pp. 19-20.

${ }^{315}$ G.M. COLOMBÁs, El monasterio, p. 99.

${ }^{316}$ J. PÉREZ-EMBID, El Císter femenino en Castilla y León. Fundación, pp. 1086-1087.

${ }^{317}$ J. C. VALLE, La arquitectura, pp. 63, 65.

${ }^{318}$ A. GARCíA, Arquitectura, p. 52.

${ }^{319}$ A. GARCíA, Arquitectura, pp. 53-54.

${ }^{320}$ A. GARCíA, Arquitectura, p. 54.

${ }^{321}$ A. GARCÍA, Arquitectura, p.54.

${ }^{322}$ J.C. RuIz SouZA, Santa María la Real de las Huelgas de Valladolid. En I. BANGo (dir.) "Monjes y monasterios", pp. 498-499. A. GARCÍA, Arquitectura, p. 56. A. GARCíA, FLORES, J" C. RUIZ SouZA. El palacio de María de Molina y el monasterio de Las Huelgas de Valladolid. Un conjunto inédito de yeserías decorativas hispanomusulmanas, "Reales Sitios", 160 (2004), p. 7-9.
} 
sentía por las órdenes mendicantes ${ }^{323}$, y puede explicarse por razones familiares. Doña María fue hija del infante Alfonso de Molina, que intervino en el establecimiento de Buenafuente ${ }^{324}$, y de Mayor Alfonso, enterrada en Palazuelos e hija del fundador del monasterio vallisoletano, Alfonso Téllez ${ }^{325}$. Probablemente a la influencia materna deba atribuirse la elección de las infantas Beatriz e Isabel, hijas de la reina María y Sancho IV, y según la tradición protectoras y artífices de la afiliación al Císter del monasterio de San Bernardo de Guadalajara ${ }^{326}$.

Para concluir con este capítulo, dedicaremos alguna atención a la rama portuguesa de la casa de Borgoña y a sus actuaciones como favorecedora del Císter.

El primo de Alfonso VI de León y primer rey de Portugal, Alfonso Enríquez (1128-1185), entregó en 1148 la ermita de San Pedro de Mouraz a Clairvaux, siendo ocupada inmedatamente por un grupo de monjes de aquella procedencia que, sin que sepamos por qué, la abandonaron inmediatamente ${ }^{327}$.

Mayor fue la fortuna de Santa María de Alcobaça, en funcionamiento a partir de $1152^{328} \mathrm{o} 1153^{329}$ igualmente por iniciativa de Alfonso Enríquez ${ }^{330}$.

Las fechas que se manejan para la adscripción al Císter de Santa María de Bouro van de mediados del siglo XII, según la propuesta de M. A. Fernandes $^{331}$, a finales de la misma centuria. Para Oliveira ${ }^{332}$, no debe ser anterior a 1174, mientras que Masoliver la retrasa aún más, situándola a finales del siglo XII ${ }^{333}$. Sabemos que Sancho I fue patrono del monasterio ${ }^{334}$, así que puede suponerse razonablemente producto de la iniciativa real pero, dependiendo de las dataciones que aceptemos, ésta correspondería a diferentes monarcas.

Por lo que se refiere al monacato femenino, éste entró en Portugal de la mano de las tres hijas de Sancho I, Teresa, Sancha y Mafalda. Hija de Sancho I y Dulce de Aragón, cuyo padre fue Ramón Berenguer IV, Teresa

\footnotetext{
${ }^{323}$ Un reciente y sagaz análisis de las devociones preferidas por la rẹina en $\mathrm{R}$. SÁNCHEZ AMEIJEIRAS, Cultura visual en tiempos de María de Molina: poder, devoción y doctrina. En M C. SeVillano San José; J. Rodríguez CoRTÉs; M. OlarTe MARTÍnEZ; L. LAHOZ (ed.) "El conocimiento del pasado. Úna herramienta para la igualdad", Salamanca, 2005, pp. 295-327.

${ }^{324}$ Vid. supra, n. 167.

${ }^{325}$ J. PÉREZ-EMBID El Císter femenino en Castilla y León. Fundación, p. 1081. M. TORRESSEVILLA, Linajes, pp. 231, 238.

${ }^{326}$ A. GARCíA, Arquitectura, p. 55.

${ }^{327}$ M.A. FERNANDES, A introdução, p. 178. En 1152 según M. DE OLIVEIRA, Origens, p. 331 y M. COCHERIL, L'implantation, p. 235.

${ }^{328}$ A. MASOLIVER, Los cistercienses, p. 121.

${ }^{329}$ M. DE OliveIRA, Orígens, pp. 338-343. M. COCHERIL, L'implantation, p. 231. M. L. ReAL, A construção, p. 49. M. A. FERNANDES, A introdução, p. 177.

${ }^{330}$ M. DE OliveirA, Orígens, p. 340.

${ }^{331}$ Como es habitual, las propuestas más tempranas corresponden a M.A. FERNANDES, $A$ introdução, p. 177, según la cuál este hecho se habría producido entre 1153 y 1174 .

${ }^{332}$ M. DE Oliveira, Orígens, p. 344.

${ }^{333}$ A. MASOLIVER, Los cistercienses, p. 522.

${ }^{334}$ M.A. Fernandes, $A$ introdução, p. 188.
} 
contrajo matrimonio en 1191 con el rey Alfonso IX de León, aunque cinco años más tarde la unión fue disuelta por causa de consanguineidad, cuando la pareja tenía ya tres hijos. Teresa volvió a Portugal con su hija pequeña, haciéndose cargo además de sus hermanas a partir de la muerte de su madre, ocurrida en 1198. En 1200 obtuvo de su padre la concesión del antiguo monasterio benedictino de Lorvão, en el que se instaló junto con un grupo de compañeras entre 1205 y 1206. La comunidad pasó a regirse por la regla cisterciense en 1211. Nunca fue abadesa, si no que desempeñó funciones semejantes a las ejercidas por la señora de algunos monasterios femeninos castellanos, especialmente el real de Las Huelgas de Burgos, en el que parece probable que se haya inspirado la reina Teresa ${ }^{335}$. Es preciso, sin embargo, recordar también que la dama, además de con Alfonso IX de León, estuvo casada con Alfonso Téllez de Meneses, hijo del fundador de Matallana y protector él mismo de Palazuelos a partir de $1213^{336}$. Muerta en 1230, fue enterrada en el coro de su fundación ${ }^{337}$.

A pesar de su separación, parece que las relaciones de doña Teresa con el rey de León fueron siempre cordiales, como demuestra el hecho de que el monarca haya tomado la defensa de su exmujer ante la amenaza del nuevo rey portugués Alfonso II, reacio al reconocimiento de la herencia paterna concedida a sus hermanas ${ }^{338}$. Además, un año antes de la muerte de la reina, Alfonso IX le proporcionó territorios para el establecimiento de una nueva comunidad femenina cisterciense en el reino de León, la de Santa María de Villabuena ${ }^{339}$.

A la muerte de la reina Dulce de Aragón, la infanta Sancha se retiró al palacio de Alenquer, una donación de su padre Sancho II donde se estableció con un pequeño séquito dedicándose a la caridad. Parece que su vocación religiosa fue decidida, pues llegó incluso a rechazar una proposición matrimonial de Fernando III ${ }^{340}$. A pesar de que favoreció especialmente a las órdenes mendicantes, su fundación preferida fue el monasterio cisterciense de Celas, establecido ca. 1215 pero que no se adscribió al Císter hasta los años veinte de ese siglo. Al igual que Teresa en Lorvão, desempeñó en su establecimiento el cargo de domina ${ }^{341}$.

\footnotetext{
${ }^{335}$ M.A. Fernandes, $A$ introdução, p. 177. M.A. Fernandes MARQues, A integração das mulheres na ordem de Cister o caso portugués. "Actas. II Congreso Internacional" I $\mathrm{p}$. I15. M A. FERNANDES MARQUES, Les premierres nonnes cisterciennes au Portugal. En B. BARRIËRE; M.H. HENNEAU (dir.), "Cîteaux et les femmes". Paris, 2001, pp. 217-220.

${ }^{336}$ Vid. supra, n. 270.

${ }^{337}$ W. RINCÓN GARCÍA, Iconografía de la santidad cisterciense en el arte portugués: las Beatas Teresa, Sancha y Mafalda. En Actas. Cister. Espaço, Territorios, Paisagens. Coloquio Internacional. 16. 20 de Junho de 1998. Mosteiro de Alcobaça. Volume II. Lisboa, 2000, p. 454.

${ }^{338}$ W. RINCón, Iconografía, p. 453.

${ }^{339}$ M.V. Herráez; M.C. COSMEn, Los promotores, p. 70. G. CAVERo DOMÍngUez, Implantación y difusión del Císter femenino hispano en el siglo XII, "Cistercium", 217 (1999) p. 799. A. GARCIA, Arquitectura, p. 49. G. CAVERO; M. A. GONZÁLEZ. El monasterio, pp. 111114 .

${ }^{340}$ W. RINCÓN, Iconografía, p. 457. 219-220

${ }^{341}$ M.A. FERNANDES, A integração, p. 117. M.A. FERNANDES, Les premières nonnes, pp.
} 
La última de las hermanas, Mafalda, no tuvo suerte tampoco en su matrimonio. Concertada su alianza con Enrique I en 1215, la reina Berenguela intentó por todos los medios conseguir una anulación que la prematura muerte del joven rey, ocurrida en 1217, hizo innecesaria ${ }^{342}$. Ese mismo año, inició las gestiones para que el monasterio benedictino de Arouca pasara a la observancia cisterciense, siendo reconocida la nueva adscripción por Honorio III en $1226^{343}$. Como Teresa y Sancha, Mafalda desempeñó igualmente el cargo de señora en su fundación ${ }^{344}$.

\section{FAMILIAS ARISTOCRÁTICAS, DAMAS NOBLES Y EXPANSIÓN DE LA ORDEN DEL CÍSTER EN LOS REINOS DE LEÓN Y CASTILLA}

Los primeros monjes blancos, como se ha explicado, se instalaron en el territorio castellanoleonés a partir de los años cuarenta del siglo XII, y lo hicieron antes que en el resto de los reinos hispánicos. El análisis de su éxito y difusión será el objeto de la última parte de este trabajo.

La introducción de la orden del Císter en España ha sido atribuida a la voluntad del propio san Bernardo ${ }^{345}$ o a la protección personal de Alfonso $\mathrm{VII}^{346}$. Aunque careciendo, creo, ambas hipótesis de fundamento, la segunda, si bien transformada, ha disfrutado de una acogida que la hace merecedora de algún comentario.

El éxito de la tesis regia dependió en gran medida de su inclusión en una teoría que adjudicaba a la orden del Císter un papel destacado en la colonización de nuevos territorios y en el afianzamiento de las fronteras supuestamente impulsado por Alfonso VII, en ocasiones a través de los magnates a los que hacía entrega de los solares monásticos ${ }^{347}$. Así, se ha llegado a decir que "los monarcas favorecerán a sus nobles por sus servicios

${ }^{342}$ W. Rincón, Iconografía, p. 460. M.A. FeRnANDES, A introdução, p. 190.

${ }^{343}$ M.H. DA CRUZ COELHO; R. CUNHA MARTINS, $O$ monaquismo feminino cisterciense e a nobreza medieval portuguesa (séculos XIII-XIV), "Theologica", 28 (1993), p. 487. 222

${ }^{344}$ M.A. FERNANDES, A integração, p. 119. M.A. FERNANDES, Les premières nonnes, $\mathrm{p}$.

${ }^{345}$ M.E. MARTín, La entrada, pp. 152-160.

${ }^{346} \mathrm{D}$. YÁÑEZ, Alfonso VII, passim.

${ }^{347}$ Esta explicación, por supuesto más extensamente desarrollada, fue por primera vez expuesta y argumentada por V.-A. ALVAREZ, Monasterios, passim y especialmente p. 241. La siguen, entre otros, C. MONTERDE, Colección diplomática, p. 253. J. L. CORRAL, La fundación, p. 37. M. C. PALLARES, El monasterio de Sobrado, pp. 119-122. E. CABRERA, En torno a. 34 1. ALFONSO, La penetración del Císter en la Península. Polémica en torno a Moreruela "Revista española de Teología, Homenaje a Federico Setgmüller”, 41, 1 (1981), pp. 149-150. E. PORTELA, La explicación, pp. 324-329. E. PORTELA SILVA, La economía cisterciense en los reinos de Castitla y León (SS. XII y XIII), "La introducción del Císter", pp. 200-205. M. J. ALONSO, Relaciones, p. 922. Aceptando en términos generales la tesis, pero intentando equilibrarla con la importancia de la iniciativa nobiliaria, P. MARTÍNEZ SOPENA, Fundaciones monasticas y nobleza en los reinos de Castilla y León en la época románica. En J. Á. GARCIA DE CORTAZAR (coord.). "Monasterios románicos y producción artística", Aguilar de Campoo, 2003, pp. 37-61" Especialmente, para esta cuestión, pp. 49-50. 
a la corona con la donación de propiedades, y es en éstas donde posteriormente se asentarán los nuevos monasterios. Por lo tanto, detrás de cada fundación nobiliaria puede verse una clara intención de la monarquía" ${ }^{348}$. Una afirmación que parece, por lo menos, discutible.

En efecto, la propuesta de V.-A. Álvarez-Palenzuela fue contestada ocho años más tarde por J. Pérez-Embid, para quien el trabajo roturador desarrollado por los monjes del Císter tendría, como mucho, una influencia secundaria en su difusión hispánica, a la vez que recordaba el eclecticismo piadoso que llevó a Alfonso VII a proteger centros religiosos de la más diversa filiación y la falta de fundamento por tanto de la tesis del afianzamiento fronterizo. La razón del éxito de los cistercienses sería, entonces, la popularidad que alcanzó entre los poderosos la aristocrática austeridad propugnada por Bernardo de Claraval ${ }^{349}$. Aunque muy probablemente esta sea, en líneas generales, la explicación correcta, creo que el problema requiere algún comentario complementario.

En primer lugar, suele olvidarse que, en realidad, Alfonso VII intervino en un escaso número de fundaciones cistercienses ${ }^{350}$ y que quizá en algunas de ellas se haya exagerado un tanto su papel. Se comentaba unas páginas más arriba como Fitero se había beneficiado de tres únicas donaciones del Emperador mientras que Huerta se vio en la necesidad de buscar nuevos protectores para sostenerse, regio descuido que parece incompatible con el papel político y fronterizo generalmente adjudicado a estas instalaciones. El monarca, por otra parte, llevaba muerto varios años cuando Sacramenia y Rioseco pasaron a depender del Císter. Alfonso VII sí se encuentra claramente relacionado sin embargo con la adscripción de Valparaíso a la orden bernarda.

Por otra parte, resulta difícil advertir la desconfianza, casi hostilidad, hacia la congregación de Cluny, supuestamente desbancada por el Císter en el favor real, que perciben algunos autores ${ }^{351}$. Claro que, como ya advirtiera C. J. Bishko, el numerario hispánico que fluía hacia Borgoña disminuyó al vaciarse el tesoro regio, como consecuencia de la desaparición de las parias ${ }^{352}$, pero esto no quiere decir que los monarcas abandonaran completamente a la Congregación. Desde luego, lo que en mi opinión no puede sugerirse siquiera

${ }^{348}$ M.J. Alonso, Relaciones, p. 922. La cursiva es mía.

${ }^{349} \mathrm{~J}$. PÉREZ-EMBID, El Císter, pp. 34-39. Recoge la crítica tanto a la tesis repobladora como a la iniciativa regia como motores de la implantación cisterciense hispánica A. RUCQUOI, Les cisterciens dans la Péninsule Ibérique "Unanimité et diversité cisterciennes. Filiations-RéseauxRelectures du XII ${ }^{\mathrm{e}}$ au XVII ${ }^{\mathrm{e}}$ siècle", Saint-Etienne, 2000, pp. 498-499, especialmente.

${ }^{350}$ Lo reducido de la nómina cisterciense adscribible a Alfonso VII fue advertido por E PORTEla, La explicación, pp. 325-329. Para soslayar este problema, el autor atribuye el papel de instrumento regio para el control del territorio a todas las órdenes reformadas, aunque no especifica a cuáles ni en qué medida, para pasar a considerar a Fernando II el gran favorecedor del Císter. No es necesario prestar aquí más atención a este problema, pues nos basta advertir que, en todo caso y aún siguiendo esta argumentación, no podría considerarse a Alfonso VII el introductor ni el principal impulsor de la orden del Císter en el reino de León.

${ }^{351}$ Esta visión, especialmente, en E. PORTELA, La explicación, p. 326.

${ }^{352}$ Véase el estudio clásico de C.J. BishKO, Fernando I y los orígenes de la alianza castellano-leonesa con Cluny, "Cuadernos de Historia de España", XLVII-XLVIIII (1968), pp. 31-135; XLIX-L (1969), pp.50-116. Para esta cuestión en concreto, vid. pp. 112-113 del segundo número. 
es que la orden cisterciense haya conseguido de los reyes de Léon y Castilla unos beneficios ni remotamente parecidos a los antaño obtenidos por Cluny, monasterio favorecido con el fabuloso census duplicatus y una privilegiadísima relación con los monarcas de los reinos occidentales hispánicos.

Efectivamente, en un análisis sin prejuicios, no podemos dejar de advertir que la protección real ejercida sobre los monasterios cistercienses, si bien importante, resulta modesta al compararla con la dispensada anteriormente a la Congregación de san Hugo. Repasando una muestra de época de Alfonso VII ${ }^{353}$, y a pesar de las diferentes circunstancias políticas, se documentan todavía donaciones abundantes a Cluny, concedidas directamente o beneficiando a monasterios hispánicos puestos en su dependencia. Las otorgadas a institutos cistercienses, aunque importantes, se diluyen en un conjunto en el que, si ha de mencionarse algún destinatario, las catedrales destacan sin duda como receptoras privilegiadas. Este eclecticismo piadoso propio del Emperador fue ya destacado por J. Pérez-Embid ${ }^{354}$ y, como se ha explicado hace unas páginas, aparece igualmente caracterizando el comportamento de otros miembros de la familia, como su hermana Sancha Raimúndez o su hija Urraca. Así, podría decirse, con B. F. Reilly, que en época de Alfonso VII "it is evident that traditional Benedictine monasticism continued to be alive, well, and well patrozined" ${ }^{355}$. Recuérdese, como muestra de esa vitalidad, que en 1142, año de la entrega de Sobrado al Císter, el rey concedía a Cluny el monasterio de San Pedro de Cardeña ${ }^{356}$.

En los restantes reinos hispánicos el panorama parece semejante, y también la confusión. Veamos el caso de Veruela, por ejemplo. Fundación de Pedro Atarés, el caballero, aunque perteneciente a la casa real aragonesa y pretendiente él mismo al trono, había sido favorecido en 1134 por Alfonso VII con el señorío de Borja ${ }^{357}$. Este hecho, sin embargo, no ha impedido que se haya presentado al promotor como un instrumento en la organización "de los territorios que el Batallador había conquistado y que ya había reestructurado política y eclesiásticamente", de modo que "en la repoblación del valle de Veruela, confluyeron pues, dos intereses yuxtapuestos a lo largo de toda la Edad Media, a pesar de algunos enfrentamientos, el de la Iglesia y el de la monarquía a través de uno de sus vasallos"358. Pero, ¿a qué monarca servía como a su señor Pedro Atarés, al que le había privado de la corona o al que le beneficiara con la concesión del territorio de Borja?, podríamos preguntarnos. Estos son los riesgos de la generalización.

\footnotetext{
${ }^{353}$ Aunque incompleto, puede encontrarse un elenco de estas donaciones en el itinerario regio recogido en la obra de M.'RECUERO, Alfonso VII, pp. 203-277.

${ }^{354}$ Vid. supra, n. 349 . Un resumen de las donaciones entregadas a las diferentes órdenes monásticas, y de la preferencia real por Cluny, Císter, Prémontre, Hospitalarios y Templarios, en B.F. REILLY, The Kingdom of León-Castilla Under King Alfonso VII, pp. 270-273.

${ }^{355}$ B.F. ReILLY, The Kingdom of León-Castilla Under King Alfonso VII, p. 270.

${ }^{356}$ B.F. REILLY, The Kingdom of León-Castilla Under King Alfonso VII, p. 271.

${ }^{357}$ J.L. CORRAL, La fundación, p. 34.

${ }^{358}$ Ibidem, p. 37.
} 
También en Portugal, recién nacido como reino independiente por aquel entonces, se ha considerado al Císter un instrumento utilizado por Alfonso I para el afianzamiento fronterizo, el dominio de la aristocracia disconforme y la repoblación rural ${ }^{359}$.

Que Alfonso Enríquez fuera el introductor del Císter en Portugal o que favoreciera decididamente a la orden desde su llegada a ese territorio resulta, cuando menos, dudoso. Para probar ese vínculo especial, M. A. Fernandes Marques se apoyó en el mismo argumento utilizado para adelantar la adscripción al Císter de Lafões: la carta de coto concedida por el rey al monasterio en $1137^{360}$. Aparte de que no se entienda bien por qué la concesión regia implicaba necesariamente la observancia cisterciense en el cenobio, conocemos ejemplos en los que estos privilegios no se otorgaban en atención a los ocupantes de una institución monástica, sino para manifestar agradecimiento o aprecio a los promotores. Así ocurrió en el caso del monasterio de Cornellana, que obtuvo su carta de coto en 1126 de un joven Alfonso VII que, en esta ocasión, no estaba interesado en agradar a la cluniacensis ecclesia, si no a Suero Vermúdez, artífice de la integración en ella del cenobio asturiano $^{361}$.

Las motivaciones que es posible imaginar para explicar la concesión a Lafões reaparecen, mejor fundamentadas, en la obtención de los cotos de Tarouca y Salzedas, monasterios favorecidos por Egas Moniz, brazo derecho de Alfonso Enríquez, y su mujer Teresa Alfonso. Los vínculos que unían al matrimonio con el monarca eran de tal naturaleza que su hijo, el infante Sancho, se crio en casa de la dama, viuda por aquel entonces ${ }^{362}$.

En realidad, ya J. Mattoso advirtió que la implantación del Císter en Portugal, aun siendo favorablemente acogida por el rey, fue por lo menos al principio posible gracias a la protección de la alta aristocracia ${ }^{363}$. El monarca se convertiría, sin embargo, en un decidido paladín de los monjes blancos a partir de la predicación de la II Cruzada, pronunciada por Bernardo de Claraval y que hizo posible la conquista de Lisboa en $1147^{364}$. Al año siguiente entregaba la ermita de San Pedro de Mouraz a Clairvaux ${ }^{365}$. Aunque los monjes franceses, por razones desconocidas, abandonaron inmediatamente el establecimiento, esta es la primera ocasión probada en la que el rey intervino directamente en una fundación cisterciense. Alfonso Enríquez expresaría más generosamente su agradecimiento algo más tarde, mediante la

\footnotetext{
${ }^{359}$ M.A. FERnANDES, $A$ introdução, p. 189. Aunque equilibrándola con otras motivaciones, vuelve sobre esta teoría M.L. REAL, A construção, pp. 51 ss.

${ }^{360}$ M.A. FERNANDES, A introdução, pp. 168-170. Vid. supra.

${ }^{361}$ M. CAlleja PUERTA, El conde Suero Vermúdez, su parentela y su entorno social. Oviedo, 2001, pp. 490-491.

${ }^{362}$ J.I. DE LA TORRE, Evolução, pp. 80-82, 87 y 97.

${ }^{363} \mathrm{~J}$. MAtToso, A nobreza medieval portuguesa e as corrientes monásticas dos séculos XI e XII. "Revista de História económica e social", 10 (Julho-Dezembro 1982), p. 43.

${ }^{364}$ J.I. DE LA TORRE, Evolução, pp. 96-97.

${ }^{365}$ M.A. FernANDES, $A$ introdução, pp. 178.
} 
creación en 1153 del monasterio de Alcobaça ${ }^{366}$, establecimiento ricamente dotado pero que, evidentemente, no desempeñó papel alguno en la introducción del Císter en la Península Ibérica.

La tesis regia, por otro lado, consideraba a los promotores aristocráticos meros intérpretes de la voluntad del monarca, basándose especialmente en el hecho de que una buena parte de los primeros monasterios cistercienses estuvieran fundados sobre territorios donados por Alfonso VII. En mi opinión, las relaciones sostenidas por el rey y sus allegados nobles en la Edad Media hispánica permitirían difícilmente esa dependencia.

En efecto, es muy frecuente que el dominio monástico primitivo proceda en buena parte de una merced real, pero los terrenos sobre los que se realizan las fundaciones sólo constituyen un reducido grupo dentro del inmenso conjunto de concesiones con que el monarca benefició a la aristocracia del reino, especialmente, pero no de manera exclusiva, a los elementos instalados en los círculos próximos al trono. Estas dádivas eran entregadas pro bono et fideli servitio y se daban, como observó H. Grassoti, en plena propiedad $^{367}$, formando parte del intrincado sistema de intercambio de beneficios característico de la sociedad medieval ${ }^{368}$. En ese régimen jurídico, los agraciados no ostentaban los derechos sobre la propiedad en nombre del rey como ocurría en el caso de las tenencias, de las que el monarca sí podía disponer, aunque generalmente permanecieran en el seno de las mismas familias $^{369}$. Que las gratificaciones reales pro bono servitio no tenían una finalidad necesariamente instrumental en el contexto de la reconquista, la repoblación y la definición fronteriza queda claramente demostrado por el hecho de que en ocasiones fueron favorecidos con ellas mujeres y judíos ${ }^{370}$.

Además, en la entrega de las propiedades a nobles que más tarde establecerán en ellas institutos cistercienses, ni una sola vez especifica el rey la regla a la que debe someterse la comunidad ${ }^{371}$. Dejando aparte el caso de Sobrado, que requiere un análisis más detenido, en esas condiciones cedió Alfonso VII Moreruela a Ponce de Cabrera, para que fundara un monasterio sin especificar de qué orden, Nogales a Vela Gutiérrez propter amore servicii quod fecistis mihi multotiens, sin entrar en más detalles ${ }^{372}$, y Sandoval a Ponce de Minerva y Estefanía Ramírez. En llamativo contraste, cuando el Emperador realice sus fundaciones directamente, expresará claramente el deseo de

\footnotetext{
${ }^{366}$ J.I. DE LA TORRE, Evolução, pp. 96-97.

${ }^{367} \mathrm{H}$. GRASSOTTI, Pro bono et fideli servitio, "Cuadernos de Historia de España”, XXXIIIXXXIV (1961), pp. 5-55. Para el pleno derecho con el que se disfrutaban estas donaciones, pp. 17, 33 y 43 , especialmente.

${ }^{368}$ Se llama la atención sobre la complejidad que presenta el análisis de la finalidad de las donaciones medievales, en este caso las otorgadas al monasterio de Cluny, y su función social, en el espléndido estudio de B.H. ROSENWEIN, To be neighbor of Saint Peter. The Social Meaning of Cluny's property. 909-1049, Ithaca and London, 1989, passim.

${ }^{369}$ S. BARTON, The aristocracy, p. 108.

${ }^{370} \mathrm{H}$. GRAsSOTTI, Pro bono, pp. 33 y 42.

${ }^{371}$ Este hecho fue percibido, para los casos de Moreruela y Sandoval, por J. PÉREZ-EMBID, El Císter, pp. 44 y 36, respectivamente.

${ }^{372}$ J. PÉREZ-EMBID, El Císter, p. 45.
} 
encomendar el establecimiento a los bernardos. Así lo hará en Valparaíso ${ }^{373}$ y Huerta ${ }^{374}$. Igual conducta seguirá su hermana Sancha en la fundación de la Santa Espina ${ }^{375}$.

S. Barton, al analizar los vínculos que unían a la monarquía y la aristocracia castellanoleonesas, bosquejó unas relaciones habitualmente basadas en la confianza recíproca ${ }^{376}$. Probablemente así sucedía en general, sólo fuera porque ambas instancias se necesitaban mutuamente, aunque no debe olvidarse que los lazos que las unían eran estrechos pero también resbaladizos. Si bien extremo, el detalladamente estudiado caso de Gonzalo Peláez, siempre rebelándose y siempre hasta el final perdonado, muestra en cuantas ocasiones se veía a veces obligado el monarca a ejercitar la regia virtud de la clemencia cuando trataba con los arrogantes aristócratas ${ }^{377}$.

Un análisis del comportamiento de la familia Traba puede resultar útil para aclarar algunos de estos problemas. Desde que Pedro Froilaz se hiciera cargo de la educación de Alfonso Raimúndez, entonces niño, el grupo se convirtió en el principal defensor de las aspiraciones del infante al trono ${ }^{378}$. Durante el banquete que siguió a la ceremonia de coronación celebrada en Santiago en 1111, el magnate gallego y sus hijos Vermudo y Rodrigo actuaron como asistentes, desempeñando Rodrigo las funciones de armiger, según relata la Historia compostellana ${ }^{379}$. En 1126, tras la muerte de la reina Urraca, Rodrigo y Vermudo se apresuraron a jurarle fidelidad ${ }^{380}$, convirtiéndose desde el año siguiente Fernando en aliado importantísimo del rey de León contra las pretensiones independentistas de Alfonso Enríquez ${ }^{381}$, a las que también se enfrentó Vermudo en $1131^{382}$. Esa lealtad, sin embargo, no impidió a Vermudo Pérez confirmar documentos emitidos por el rey de Portugal en

${ }^{373}$ Vid. supra, n. 280.

${ }^{374}$ Vid. supra, n. 290.

${ }^{375}$ Vid. supra, n. 292.

${ }^{376}$ S. BARTON, The aristocracy, pp. 104-107.

${ }^{377}$ E. GARCíA GARCíA, El conde asturiano Gonzalo Peláez, "Asturiensia Medievalia”, 2 (1975), , pp. 39-64.

${ }^{378}$ M. ReCUero, Alfonso VII, p. 54. S. BARTON, The aristocracy, pp. 14 y 112.

379 "Deinde, missa ex more solempniter celebrata, regem nouum deducens ad palatium suum episcopus omnes Gallicie proceres ad regale inuitatuit conuiuium, in quo clarissimus comes Petrus regius dapifer extitir eiusque filius Rudericus clipeum et frameam ad regis scapulas alferecis tenuit". E. FALQUE REY (ed.). Historia compostellana, Corpus Christianorum. Continuatio Medievalis, LXX. Turnholti, MCMLXXXVIII, I LXVI, p. 106. Hay traducción: E. FALQUE REY (introducción, traducción, notas e índices). Historia compostelana Madrid, 1994. Para el contexto político que explica la coronación del infante como rey de Galicia, B.F. REILLY, The Kingdom of León-Castilla under Queen. Urraca 1109-1126. Princeton, 1982, pp. 45-85. Disponible en versión electrónica en Ta siguiente dirección: http://libro.uca.edu/urraca/urraca12. htm.

${ }^{380}$ M. RECUERO, Alfonso VII, p. 79.

${ }^{381}$ Ese año Alfonso VII alcanzó un acuerdo con Teresa de Portugal, que fue amante primero y más tarde se casó con Fernando Pérez. M. RECUERO, Alfonso VII, pp. 95 y 150 . B. F. REILLY. The Kingdom of León-Castilla Under King Alfonso VII, pp. 23-25. S. BARTON, The aristocracy, p. 127 .

${ }^{382}$ B.F. ReILLY, The Kingdom of León-Castilla Under King Alfonso VII, pp. 36-37. 
1131, 1143 y $1145^{383}$. Los dos hijos de Pedro Fróilaz se habían unido a la familia real portuguesa mediante lazos matrimoniales. Fernando no parece haber estado nunca en buenos términos con el monarca luso, que no aprobaba las relaciones entre el magnate y su madre Teresa ${ }^{384}$, y en consecuencia abandonó Portugal a la muerte de ésta ${ }^{385}$. Pero él no fue el único Traba enlazado con los Enríquez, pues Vermudo había contraído matrimonio en 1122 con Urraca, una de las hijas de Teresa Alfonso y Enrique de Borgoña ${ }^{386}$.

Desde que S. Barton, además, identificara como Rodrigo Pérez de Traba, uno de los hijos de Pedro Fróilaz, al comes Rodericus Petri Villosus que aparece en la Chronica Adefonsi Imperatoris acompañando a Alfonso Enríquez en la invasión de Galicia efectuada en $1137^{387}$, sabemos que no toda la familia apoyaba a Alfonso VII. Armiger en la celebración compostelana de $1111^{388}$, presente en el grupo que juró fidelidad al joven rey en $1126^{389}$, conde desde 1127 por merced regia ${ }^{390}$, desconocemos las razones que le llevaron a pasarse al bando portugués. El Emperador, probablemente a ruegos de su familia, le otorgó el perdón dos años después de la rebelión, aunque no volverá a frecuentar la corte hasta $1152^{391}$.

Lo que interesa destacar en este momento es que, incluso en el grupo de los más fieles aliados del monarca, algunos de sus miembros mantienen una cierta independencia cuando no se declaran en abierta rebeldía.

Creo que el análisis de la fundación de Sobrado confirma la dificultad de considerar a los grandes aristócratas del siglo XII meros instrumentos de la política regia.

Hace unas páginas se explicaba cómo el monasterio de Sobrado, arrebatado por Fernando I de León a los antepasados de Urraca Fróilaz, la primera mujer del conde Pedro Fróilaz, había sido devuelto a los hijos de ésta, Fernando y Vermudo, por la reina Urraca y el infante Alfonso en $1118^{392}$. Por supuesto, resulta imposible que en este momento se pensara en la creación de un establecimiento cisterciense. Varios pasajes del documento ${ }^{393}$ indican que la concesión es en realidad una restitución. En primer lugar, se especifica el nombre de los propietarios legítimos, Segeredo Alviti y Adosinda Arie, a los que les fue arrebatado violenter. Pero, además, debe advertirse que

${ }^{383}$ J. MATTOSO, A nobreza medieval galaico-portuguesa, pp. 175-176.

${ }^{384}$ B.F. ReILLY, The Kingdom of León-Castilla Under King Alfonso VII, p. 24.

${ }^{385} \mathrm{~J}$. Mattoso, A nobreza medieval galaico-portuguesa, p. 175.

${ }^{386} \mathrm{~J}$. MATTOSO, A nobreza medieval galaico-portuguesa, p. 176. S. BARTON, The aristocracy, p. 53

${ }^{387}$ S. BARTON, Sobre el conde Rodrigo Pérez "el Velloso", "Estudios Mindonienses" (1985), pp. 653-661.

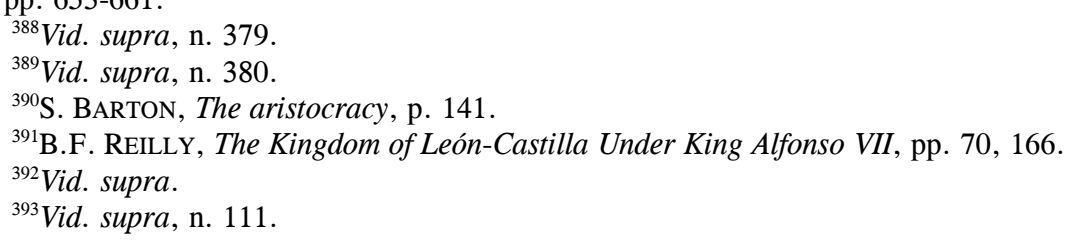


los beneficiarios de la devolución son, no todos los hijos de Pedro Fróilaz sino exclusivamente los que el magnate había tenido con Urraca, la heredera de la propiedad incautada, es decir, Uermudo Petri y Fernando Petri ${ }^{394}$. Se trata además de una de esas donaciones que utilizan la fórmula pro bono servicio, buen ejemplo de que estas acciones no siempre beneficiaban a receptores de fidelidad probada pues los Traba, aunque en ese momento aliados de conveniencia, no se encontraban generalmente en buenas relaciones con la reina Urraca, ya que los intereses del hijo, al que apoyaban, no solían coincidir con los de la madre.

Así pues, cuando Sobrado fue entregado a la orden del Císter, hacía ya tiempo que se encontraba de nuevo en manos de los hijos habidos por Pedro Froilaz y su esposa Urraca. Claro que el Emperador aparece en el documento de donación, apoyándola con su consilio et iussione et fortitudine ${ }^{395}$, lo que suele interpretarse como una muestra del interés real por la implantación del Císter ${ }^{396}$, aunque quizá no sea más que una manifestación de reconocimiento a la familia que le había ayudado en los tiempos difíciles, en una línea que excluía además al rebelde conde Rodrigo, perdonado desde 1129 pero al que no encontraremos de nuevo en la corte hasta $1152^{397}$.

Varios síntomas indican el interés especial del grupo Traba por su fundación de Sobrado. Vermudo, que aparece como donante indirecto a través de su hija Urraca, tomará una determinación significativa: hacia 1156, unos doce años antes de su muerte, acaecida en 1168 , se retirará al monasterio familiar ${ }^{398}$ y allí, monachum se constituit ${ }^{399}$. Claro que cualquier fundador podía esperar, a pesar del movimiento reformista, ser acogido en su vejez en el establecimiento que protegía, pero resultaba más habitual que el privilegio fuera aprovechado por las damas nobles ${ }^{400}$. Además, el cambio de estado de Vermudo se produjo viva aún su esposa, a su vez instalada en Noguerosa ${ }^{401}$, lo cuál no es excepcional pero sí infrecuente. Es interesante señalar que Pedro Enríquez, un hermano de su mujer Urraca, se retiró también a un monasterio cisterciense, el de Alcobaça, en $1163^{402}$. Vermudo Pérez recibirá además sepultura en el claustro de Sobrado ${ }^{403}$.

Es bien conocida la resistencia cisterciense a aceptar enterramientos en el interior de sus recintos, y también cómo paulatinamente fueron cediendo

\footnotetext{
${ }^{394}$ Rodrigo, García y Velasco fueron producto de otro matrimonio del conde Pedro. M. RECUERO, Alfonso VII, p. 79.

${ }^{395}$ Vid. supra, n. 107.

${ }^{396}$ M.C. PALLARES, El monasterio de Sobrado, pp. 119-122.

${ }^{397}$ Vid. supra, n. 391.

${ }^{398}$ S. BARTON, The aristocracy, p. 57.

${ }^{399}$ El mismo Vermudo Pérez relata este hecho en la avenencia con los monjes del monasterio de Toxos Outos. 1161, septiembre 21. Santiago de Compostela. AHN, Clero 556/4. Publicado por S. BARTON, The aristocracy, $\mathrm{n}^{0}$ XII del apéndice documental, pp. 320-322.

${ }^{400}$ S. BARTON, The aristocracy, pp. 202-203.

${ }^{401}$ S. BARTON, The aristocracy, p. 215.

${ }^{402}$ A. RUCQUOI, Les cisterciens, p. 502.

${ }^{403}$ Noticia proporcionada por J.L. LÓPEZ, La nobleza, p. 62.
} 
ante la presión señorial. Mientras que los estatutos de 1134 sólo toleraban a un amigo o dos de cada monje ser enterrado en el cementerio de laicos, ya en 1157 se aceptaron las inhumaciones de fundadores dentro del monasterio. Puesto que la primera estancia afectada por estas medidas liberalizadoreas fue el claustro ${ }^{404}$, y sabemos que en territorio hispánico estos recintos se utilizaban como lugares de inhumación desde fines del siglo XII ${ }^{405}$, puede aceptarse razonablemente la noticia relativa a Vermudo Pérez. Es interesante advertir que, a pesar de su profesión monástica, el viejo aristócrata no encontró reposo en el cementerio común de los monjes ${ }^{406}$, si no en un espacio privilegiado, prohibido todavía el interior del templo ${ }^{407}$.

A pesar de la reticencia a la que se ha hecho referencia, los monasterios bernardos serán frecuentemente reclamados como lugar de enterramiento, quizá por su propia exclusividad. Es cierto que la extensión peninsular de la reforma cluniacense se había basado, entre otras razones, en idéntica pretensión aristocrática ${ }^{408}$, además de en su conocida especialización en una suntuosa liturgia de difuntos ${ }^{409}$. Pero, aunque la orden del Císter haya reducido en parte la gestualidad y el boato proverbiales en Cluny ${ }^{410}$, no debe olvidarse que los monjes blancos potenciaron sin embargo algunas estrategias alternativas. En primer lugar, como advierte J. Mattoso, los bernardos redujeron las conmemoraciones por los benefactores laicos, pero aumentaron sin embargo extraordinariamente las que se celebraban en sufragio de los miembros de la orden y también, aunque en menor medida, las de sus familiares más próximos ${ }^{411}$. De todas esas prerrogativas debía beneficiarse Vermudo al ingresar en la clausura de Sobrado. Pero, además, según expusiera M. Cassidy-Welch en un estimulante estudio dedicado al significado

${ }^{404}$ M. AUBERT, L'architecture cistercienne en France. I. Paris, MCMXLVII, pp. 329-349.

${ }^{405} \mathrm{~A}$. GARCíA FLORES, Espacios funerarios en los monasterios cistercienses de los reinos de Castilla y León (siglos XII al XV), "Cîtẹaux. Comentarii Cistercienses", 56 (2005), p. 221. Para el uso funerario de los claustros hispánicos, E. CARRERO SANTAMARÍ,' El claustro funerario en el medievo o los requisitos de una arquitectura de uso cementerial, "Liño", 12 (2006), pp. 31-43.

${ }^{406}$ Los monjes cistercienses se enterraban en un cementerio situado al norte de la iglesia, sin monumento funerario alguno que marcara la tumba. E. DABROWSKA Le rite funérarire prope à l'ordre de Cîteaux. Son développemet, sa réception, ses filiations. "Unanimité", p. 226.

${ }^{407}$ Aunque no se conserve, parece que la iglesia medieval se había iniciado hacia 1160. J. C. VALLE, La arquitectura, p. 66. Para la jerarquización de los enterramientos en monasterios cistercienses, vid. E. CARRERO SANTAMARIA, Arte y liturgia en los monasterios de la orden del Císter. La ordenación de un "ambiente estructurado" "Actas del III Congreso internacional sobre el Cister en Galicia y Portugal, Orense, 22-24 de diciembre de 2005", Orense, 2006, vol. I, pp. 503-565..

${ }^{408} \mathrm{~J}$. MATTOSO, A nobreza medieval portuguesa, p. 34.

${ }^{409}$ Para el origen de la conmemoración cluniacense de los difuntos, breve pero autorizado, $\mathrm{M}$. HugLO, L'office de prime au chapitre. En J.-L. LEMAITRE (comp.). "L'église et la mémoire des morts dans la France médievvale , Paris, 1986, pp. 11-18.

${ }^{410} \mathrm{~J}$. WOLlASCH, Les moines et la mémoire des morts. En D. IOGNA-PRAT; J-C. PICARD (études réunies par), "Religion et culture autour de l'an mil. Royaume capétien et Lotharingie". Cahors 1990, pp. 47-54. J. MATTOSO, O culto dos mortos em Cister no tempo de sãot Bernardo. En J. MATTOSO (dir.), "O reino dos mortos na idade média peninsular", Lisboa, 1996, pp. 87107.

${ }^{411}$ J. MATtOSO, O culto, p. 103. 
de los espacios cistercienses de Yorkshire ${ }^{412}$, los recintos monásticos, heredados de la tradición, adquirieron nuevos contenidos en la orden reformada. A diferencia de las costumbres benedictinas anteriores, la liturgia cisterciense hacía un uso restringido de las procesiones claustrales ${ }^{413}$. Presididas generalmente por el subdiácono seguido del diácono, que llevaba la cruz, en ellas tomaban parte activa, junto a los monjes, huéspedes y visitantes, llevando palmas en la celebración del Domingo de Ramos y velas en la Candelaria ${ }^{414}$. En territorio hispánico, sabemos que en el siglo XVI, probablemente continuando prácticas anteriores, a la celebración en el claustro de Poblet de la ceremonia del mandatum y la procesión del Viernes Santo asistían los laicos, "hombres y mujeres buenos", según indican las fuentes ${ }^{415}$. Creo que, incluso a los más habituales seguidores de la teatralizada liturgia cluniacense debieron impresionarles estas solemnidades, más emotivas por infrecuentes y por involucrar activamente a los que antes no eran más que espectadores. También de estas devociones se beneficiaba la memoria de Vermudo Pérez, presente en su tumba para los asistentes a estos recorridos piadosos.

Además, antes de que los estatutos de 1180 aceptaran el enterramiento de los abades en la Sala Capitular, retornando así a los usos benedictinos, los restos de los rectores de Cîteaux y Clairvaux se depositaban en un loculus, común y abierto al claustro, una tumba colectiva que era saludada por los monjes varias veces al día, al dirigirse a los oficios. Esta costumbre era también seguida en otros monasterios franceses, alemanes, ingleses y escandinavos $^{416}$, pero desdichadamente desconocemos si también se respetaba en España.

Sobrado se convertirá, a partir de la inhumación del magnate de los Traba, en un lugar especialmente reclamado por sus descendientes directos como lugar de enterramiento. Allí desearon reposar sus hijos Suero (m. 1169) y Teresa Vermúdez (m. después de 1216) ${ }^{417}$, mientras Sancha, en 1219, disponía que su memoria fuera recordada en el Capítulo ${ }^{418}$, asociándose de esta manera a las súplicas por todos los miembros y benefactores de la orden difuntos que se realizaban cotidianamente ${ }^{419}$. El mismo destino final escogieron los hijos de Teresa: Egidio (m. después de 1240), Enrique (m.

\footnotetext{
${ }^{412}$ M. CASSIDY-Welch, Monastic Spaces and their Meanings. Thirteenth-Century English Cistercian Monasteries, Turnhout, 2001.

${ }^{413}$ Para los usos litúrgicos del claustro cisterciense, se ha seguido a M. CASSIDY-WELCH, Monastic, pp. 58-65 y a E. CARRERO. Arte y liturgia.

${ }^{414}$ M. CASSIDY-WELCH, Monastic, pp. 58-65.

${ }^{415} \mathrm{~F}$. ESPAÑOL BERTRÁN, La polifuncionalidad de un espacio restringido. Los usuarios religiosos y la satisfacción de las necesidades comunitarias. En J. YARZA LUACES; G. BOTO VARELA (coord.), "Claustros románicos hispanos", León, 2003, pp. 20-21.

${ }^{416}$ E. DABROWSKA, Le rite, pp. 224-225.

${ }^{417}$ Según el Memorial de Sobrado. Se ha manejado la transcipción incluída en la obra de J. L. LÓPEZ, La nobleza, pp. 204-205.

${ }^{418}$ J.L. LÓPEZ, La nobleza, p. 74.

${ }^{419}$ M. AUBERT, L'architecture, II, p. 51. M. CASSIDY-WelCH, Monastic, p. 113.
} 
después de 1233) y Gil Fernández (m. después de 1241) ${ }^{420}$. Por lo que sabemos, en el resto de las ramas familiares estas disposiones se tomaron sólo aisladamente: Suero Menéndez, llamado "Zapata" (m. después de 1166) ${ }^{421}$, y su hermano Vermudo (m. después de 1200) ${ }^{422}$, nietos de Rodrigo, un hermano de Pedro Fróilaz, y Velasco Fernández (m. después de 1190), nieto de Fernando Pérez, que deseó enterrarse en el capítulo monástico ${ }^{423}$, un enterramiento de gran privilegio, por cierto, pues allí se depositaba a los abades después de $1180^{424}$, son los únicos que dispusieron su tumba en el monasterio. No conocemos los lugares de enterramiento de la mayor parte de estos personajes, aunque resulte tentador suponer que la capilla adosada al crucero de la iglesia cuya función funeraria estableció J. C. Valle Pérez ${ }^{425}$ haya sido en realidad el panteón familiar. Dispuesto de esta manera o con otra organización, el agrupamiento sepulcral contribuyó sin duda a asegurar, y a hacer visible, además, la conciencia familiar ${ }^{426}$.

Las disposiciones que Fernando Pérez (¿m. 1155?) tomó para su enterramiento fueron otras, pues eligió, como su padre Pedro Fróilaz, descansar en la catedral de Santiago ${ }^{427}$. Quizá la fecha de su muerte, anterior a las nuevas normas emanadas del Capítulo de 1157, haya impedido una inhumación en Sobrado, o simplemente no la deseó. La preferencia de esta rama de la familia por la sede compostelana debió de ser poderosa, pues María Fernández, a pesar del papel desempeñado junto a su marido Ponce de Cabrera en la fundación de Moreruela, le destinó igualmente su cuerpo ${ }^{428}$.

Así, parece que fueron los descendientes de Vermudo los principalmente interesados en obtener enterramiento en Sobrado. Puesto que M. C. Pallares y E. Portela demostraron el cognatismo que en estos momentos dominaba al grupo familiar ${ }^{429}$ y no se puede por tanto suponer una sucesión lineal que excluyera a los parientes colaterales, quizá esta preferencia muestre

\footnotetext{
${ }^{420}$ J.L. LÓPEZ, La nobleza, pp. 71-74.
}

${ }^{421}$ J.L. LÓPEZ, La nobleza, p. 46.

${ }^{422}$ Junto con su mujer Eldara Froila: "si autem ad obitum meum et uxoris mee domne Eldare concedis nobis sepulturam in vestro monasterio et debitum facere pro nobis quantum pro uno ex vobis". M.C. PALLARES, El monasterio de Sobrado, p. 222.

423 "Preterea mando me sepeliri in monasterio vestro si contingerit me mori in Galletia et vos conceditis mihi pro vestra bona voluntate sepultura in vestro capitulo et partem in orationibus vestris". M.C. PALlARES, El monasterio de Sobrado, p. 222.

${ }^{424} \mathrm{M}$. AUBERT, L'architecture, I, pp. 331-332. I. BANGO TORVISO, El ámbito de la muerte. En I. BANGO (dir.), "Monjes y monasterios", pp. 325-327.

${ }^{425}$ J.C. VAlle PÉREZ, La capilla de san Andrés, en el monasterio de Oseira y las capillas funerarias en la arquitectura cisterciense de Galicia. En J.C. VALLE PÉREZ (et al.), Boletín auriense. Monacato galego $\mathrm{s}_{\text {s }}$ exquimilenario de san Bieito: actas do primeiro coloquio, Ourense 1981. Ourense, 1986, pp. 100-103.

${ }^{426}$ Para las tumbas y conmemoraciones como sistema cohesionador, en el ámbito carolingio, C. TREFFORT, L'église carolingienne et la mort. Christianisme, rites funéraires et pratiques conmémoratives, Lyon, 1996, pp. 175-177.

${ }^{427}$ J.L. LÓPEZ, La nobleza, pp. 41, 99-100.

${ }^{428}$ J.L. LÓPEZ, La nobleza, pp. 99-100.

${ }^{429}$ M.C. Pallares; E. Portela, Aristocracia, pp. 823-840. 
a unos hijos deseosos de beneficiarse de la íntima relación establecida por su padre con la rigorista orden cisterciense.

Presentes en sus enterramientos, recordados en las oraciones de los monjes, los miembros de la familia encontrarán también un lugar de privilegio en los registros monásticos. Los Tumbos de Sobrado, escritos en la primera mitad del siglo XIII, o en los años centrales de la centuria ${ }^{430}$, incluyen unos interesantísimos capítulos genealógicos que desgraciadamente no precisan la fecha de redacción. No se pretende aquí realizar un estudio detallado del material, abundante y complejo ${ }^{431}$, pero sí interesa destacar algunos de sus aspectos. Una de las composiciones está dedicada a la prole de Pedro Fróliaz ${ }^{432}$ :

De domno Petro Froyle natus est comes domnus Fernandus et domnus Ueremudus et domnus Garssia et domnus Uelascus et comes domnus Rodericus dictus Uelusu et domna Luba.

Aquí se incluyen los hijos del magnate sin exclusiones. Además, no es esta la única línea familiar que interesa al redactor, recogiéndose en otro pasaje la descendencia de Rodrigo Fróilaz, hermano de Pedro y abuelo del Suero Menéndez "Zapata”, recordémoslo, enterrado en Sobrado ${ }^{433}$. Puesto que también miembros de la familia pertenecientes a diferentes líneas otorgan donaciones al cenobio ${ }^{434}$, podemos suponer que éste, con mayor o menor intensidad, interesaba a todo el grupo. Naturalmente, la fijación por escrito de los beneficios obtenidos es el principal motivo por el que se incluyen en el Tumbo estas relaciones genealógicas ${ }^{435}$ pero, aunque por razones interesadas, el hecho es que la memoria familiar empieza a ser custodiada por una institución monástica, como sucedía, al menos desde la primera mitad del siglo XI, en algunas regiones de Francia ${ }^{436}$.

${ }^{430}$ Según P. LOSCERTALES, Tumbos, I, p. 9, corresponderían a la primera mitad del siglo XIII. A mediados para E. PORTELA; M.C.PAALLARES, El sistema antroponímico en Galicia. Siglos IX a XIII. En P. MÁRTÍNEZ SOPENA (coord.) "Antroponimia y Sociedad. Sistemas de identificación hispanocristianos en los siglos IX a XIII", Valladolid, 1995, p. 21.

${ }^{431}$ Un breve análisis desde el punto de vista genealógico ha sido realizado por C. SÁEZ y M. J. VÁOUEZ MADRUGA, Genealogías del monasterio dé Sobrado (s. X-XI). En C. SÁEZ; J GÓMEZ-PANTOJA (ed.), "Las diferentes historias de letrados y analfabetos". Ailcalá de Henares, 1994 pp. 39-55. Los autores no parecen haber advertido las relaciones familiares que pueden percibirse entre, por lo menos, algunas de las diferentes generaciones.

${ }^{432}$ P. LOSCERTALES, Tumbos, II, $\mathrm{n}^{\circ} 112$, pp. 249-250.

433،Rodericus Froyle habuit tres filios: Menendum Roderici et Gundisaluum Roderici et Froylam Roderici. De Menendo Roderici natus est Suerius Menendi, qui dictus est Zapata (...). De Gundisaluo Roderici natus est Fernandus Gundisalui et Elvira Gundisalui et Gundisaluus Gundisalui". P. LOSCERTALES, Tumbos, I, n 212 , p. 249.

${ }^{434}$ Vid. supra, n. 115. p. 44

${ }^{435}$ Esta motivación económica fue advertida por C. SÁEZ y M.J. MAdRUGA, Genealogías,

${ }^{436} \mathrm{M}$. LAUWERS, La mémoire des ancêtres, le souci des morts. Morts, rites et société au Moyen Age, Paris, 1996, p. 293. 
Sin embargo, no todos los miembros del grupo reciben el mismo tratamiento. La última pieza de esta colección sobre la que llamaré la atención destaca claramente a los fundadores del monasterio ${ }^{437}$ :

De comite domno Menendo natus est Rodericus Munit. De Roderico Muniz Guter Roderiquit. De Guter Roderiquit, Didaco Guter et Rodericus Guter. De Didaco Guter, Ardiu Diat et Azenda Diat. De Roderico Guter, Munio Roderici de Mirumferar. De Ardiu Diat que fuit uxor comitis domni Froyle, nata est Vrraca Froyle que fuit uxor comitis domni Petri. De comite domno Petro nati sunt comes domnus Fernandus et domnus Veremudus Petri, qui fundauerunt monasterium Supperadi et miserunt ibi ordinum Cistercii, et domnus Veremudus fuit ibi in ordinem frater et ibi uitam finiuit.

En ella destacan varios detalles. En primer lugar, excepcionalmente, los protagonistas adquieren rasgos biográficos: fundan monasterios, profesan en ellos. Claro que ese es el perfil que interesa mostrar a la comunidad defensora de sus derechos y propiedades pero, de todos modos, algunos miembros del grupo adquieren así un relieve mejor definido en las memorias familiares. Pero creo que el aspecto más destacable es la línea genealógica seguida en esta ocasión, la materna. Por supuesto, la selección manifiesta la capacidad de las mujeres de esa época como transmisoras de patrimonio ${ }^{438}$. Ahora, sin embargo, interesa advertir la manera en la que se recuerda el origen familiar de los derechos sobre Sobrado, insistiéndose de ese modo en el carácter reparatorio de la donación real.

Se considera probado que, en comparación con el resto de Europa, en los reinos occidentales hispánicos la conciencia del linaje, entendida como sucesión lineal maculina que excluye a los parientes colaterales, se impone con retraso y también en consecuencia los símbolos externos que la $\operatorname{muestran}^{439}$. Ni siquiera la generalización del uso de los nomina paterna, sistema antroponímico dominante a partir de mediados del siglo XII, parece que pueda ser tenida por un indicio de la imposición de la sucesión agnática ${ }^{440}$. Sin embargo, y a pesar de esta peculiaridad hispánica, a partir de ese momento pueden encontrarse costumbres que muestran un interés creciente por la exposición de los vínculos familiares y el origen antiguo y noble del grupo: los emblemas parlantes empiezan a ser utilizados por los aristócratas en sus escudos, como la cabra usada por Ponce de Cabrera que aparece en la

\footnotetext{
${ }^{437}$ P. LOSCERTALes, Tumbos. I, $\mathrm{n}^{\circ}$ 423, p. 385. La negrita es mía.

${ }^{438}$ Estudiada esta cuestión para el grupo de los Traba por M.C. PALlares; E. PORTELA, Aristocracia, p. 839, especialmente.

${ }^{439}$ Aunque dedicado a la Baja Edad Media, puede encontrarse un buen panorama de este problema en I. BECEIRO PITA, La conciencia de los antepasados y la gloria del linaje en la Castilla bajomedieval. En R. PASTOR (comp.). "Relaciones de poder, de producción y parentesco en la Edad Media y Moderna". Madrid, 1990, pp. 329-349.

${ }^{440}$ E. Portela; M.C. PALlares, El sistema, pp. 21-47. En este trabajo se aborda esta cuestión utilizando precisamente los Tumbos de Sobrado como fuente de información.
} 
ilustración de un diploma de 1150 , por ejemplo ${ }^{441}$. Aproximadamente por los mismos años, las donaciones piadosas por los parientes parecen incluír entre sus motivaciones la manifestación de las solidaridades familiares ${ }^{442}$. En fin, desde las primeras décadas del siglo XIII, se construirán capillas adosadas a los muros de las iglesias cistercienses que, respetando la rigurosa normativa del Císter, acogían con dignidad a sus fundadores y benefactores ${ }^{443}$.

Así pues, si bien para el caso de los Traba "el examen de la transmisión de bienes, el estudio de la herencia, (...) no sólo confirma la inexistencia del linaje, sino que ofrece buenas pruebas de una ordenación diferente" ${ }^{444}$, entre los años centrales del siglo XII y la primera parte de la siguiente centuria, puede sospecharse que la familia, organizada de la manera que fuere, empezó a mostrar su conciencia de grupo a través de diversas acciones representativas. Aunque en un trabajo de carácter general no sea posible llevar más allá las conclusiones, fundación monástica, enterramientos familiares y relaciones genealógicas lo indican.

Aún es más evidente la importancia que la representación señorial alcanzó en los monasterios femeninos, una relevancia que debe, al menos en parte, explicarse en relación a la independencia que las damas castellanas conservaron en una Europa en la que las mujeres eran cada vez menos poderosas $^{445}$. Así, podría aplicarse también a las aristócratas la observación hecha a propósito de las reinas españolas: "unlike northern queens, however, Spanish royal women were more likely to be active in the governance of the realm" ${ }^{446}$. Sin embargo, y a pesar de que "al lector de las crónicas castellanoleonesas medievales debería llamarle la atención - extrañamente no ha sido el caso hasta ahora - la importancia que cobra en ellas la mujer", presencia además constante en la esfera del poder ${ }^{447}$, estos problemas no han sido atendidos prácticamente en lo que concierne a los años centrales de la Edad Media castellano-leonesa. Sí se han advertido estas peculiaridades hispánicas durante la época altomedieval, atribuyéndolas al sistema de sucesión extenso que garantizaba a las mujeres el acceso a la herencia y la capacidad para disponer de sus propios bienes, así como la posibilidad de ejercitar el poder

\footnotetext{
${ }^{441}$ Identificado por E. FERNÁNDEZ-XESTA, Un magnate, p. 50. Otros ejemplos y algunas reflexiones acerca de esta cuestión, en M. CALLEJA, El conde, pp. 201-216. 106.

${ }^{442}$ Estudiadas, para el caso de los López de Haro, por G. BAURY, Les religieuses, I, pp. 105

${ }^{443}$ Vid., por todos A. GARCía, Espacios funerarios, pp. 215-220.

${ }^{444}$ M.C. Pallares; E. PORTEla, Aristocracia, p. 838

${ }^{445} \mathrm{Un}$ reciente trabajo de M. F. Coelho considera que la fundación en León de monasterios cistercienses femeninos cuando no había intención de someterse a las normas reformadas respondía a una simple moda. M.F. COELHO, Expresiones del poder feudal: el Císter femenino en León (siglos XII y XIII), p. 55. En las líneas que siguen explicaré las razones de m disconformidad con esa tesis, y la causa de las peculiares circunstancias del monacato femenino castellanoleonés.

${ }^{446}$ T. EARENFIGHT, Partners in Politics. En T. EARENFIGHT (ed.) "Queenship and Political Power in Medieval and Early Modern Spain", Cornwall, 2005, p. XîII.

${ }^{447}$ G. MARTIN, Berenguela de Castilla (1214-1246): en el espejo de la historiografía de su época. En I. MORANT (dir.) "Historia de las mujeres en España y en América Latina. I. De la prehistoria a la Edad Media". Madrid, 2005, p. 569.
} 
más allá de los límites domésticos, especialmente en el caso de las viudas ${ }^{448}$. No parece tan claro, sin embargo, que, como se ha supuesto, todas estas capacidades hayan sido perdidas por las mujeres castellanas en el curso de los siglos posteriores ${ }^{449}$. A la espera de un necesario estudio monográfico, varios indicios indican lo contrario. Por un lado, debe destacarse la importancia del poder político alcanzado por algunas mujeres del entorno real como la infanta Sancha Raimúndez o Berenguela de Castilla ${ }^{450}$, y el hecho de que la negativa visión de la reina Urraca que, a la postre, se impuso en la historiografía, no comenzara a insinuarse en las crónicas hasta el siglo XIII ${ }^{451}$. Por otro, sabemos que, en ocasiones al menos, las damas nobles intervenían en defensa de los intereses familiares de manera activa y competente. Así, al enviudar la condesa Aldonza de Lope Díaz (m. 1170), la dama dirigió la poderosísima familia de los Haro hasta la afirmación del heredero ${ }^{452}$.

El caso de los monasterios femeninos resulta particularmente interesante a este propósito. La tradición cenobítica altomedieval regulaba la manera en la que hombres y mujeres podían compartir el mismo espacio monástico. No sólo se hacía así en el caso de los monasterio dúplices, sino también garantizando alojamiento a mujeres, generalmente pertenecientes a la familia promotora, en monasterios masculinos ${ }^{453}$. En teoría, este estado de cosas debería haber sido anulado por la reforma monástica y, especialmente, por la ordenación cisterciense, que prescribe una rigurosa clausura. Pero la nueva situación, en realidad, parece que fue bastante permisiva. Por una parte, y superada la concepción de la cura monialum como sistema de dominio masculino a favor de otras interpretaciones más complejas ${ }^{454}$, es necesario advertir que la necesidad de asistencia litúrgica y sacramental debió de configurar en la práctica, en los monasterios más ricos al menos, una composición dúplice cuando teóricamente esta organización había sido ya

${ }^{448}$ M.C. PALlaRes, Grandes señoras en los siglos IX y X .En I. MoRANT (dir.), "Historia”, pp. 423-442.

449 “Después, la mayoría de las mujeres de la aristocracia perdió capacidad de proyección social. Religiosas o laicas, sus acciones tuvieron, en general menos repercusión fuerá de los muros del convento o en el exterior del espacio domestico. Y aquellas que la alcanzaron fue venciendo una mentalidad firmemente asentada en la supremacía del varón”. Ibidem, p. 441.

${ }^{450}$ L. GARCía, Doña Sancha, passim; G. MARTIN, Berenguela, pp. 569-594. J. F. O'Callaghan, The Many Roles of the Medieval Queen: Some Examples from Castile. En T. EARENFIGHT (ed.), "Queenship", pp. 21-32.

${ }^{451}$ Para un análisis en esta perspectiva de las fuentes que informan acerca de las actuaciones de la reina Urraca, T. MARTIN, De "gran prudencia, graciosa habla y elocuencia" a "mujer de "Compostellanum". L, 1-4 (enero-diciembre 2005), pp. 551-578. Ya advirtió la excepcionalidad de Urraca en relación con Europa B.F. REILLY, The Kingdom of León-Castilla under Queen Urraca, p. 352. Sobre las características del reinado de Urraca en su contexto, C. GARCIA. Le pouvoir d'une reine. L'image d'Urraque I're (1109-1126) dans les Crónicas anónimas de Sahagún. "E-spania. Revue électronique d'études hispaniques médiévales", 1 (2006), pp. 1-22. http://www.e-spania.paris-sorbonne.fr/article-pdf/garcia.htm.

${ }^{452} \mathrm{G}$. BAURY, Les religieuses, I, p. 198.

${ }^{453}$ J. MATTOSO, O monaquismo tradicional em Portugal no seculo XII, "La introducción del Císter", p. 59.

${ }^{454}$ F.J. GRIFFITHS, Men's duty to provide for women's needs": Abelard, Heloise, and their negotiation of the cura monialum, JMH, 30, 1 (March 2004), pp. 1-24. 
desterrada por la reforma ${ }^{455}$. Catorce capellanes atendían a las dueñas de las Huelgas de Burgos entre 1226 y 1250, sólo dos más de los que se encontraban al servicio de las de Santa María de Cañas más o menos por las mismas fechas. Esta inflación del colegio clerical asociado a los monasterios femeninos importantes generó unos problemas arquitectónicos y de organización monástica que requieren un estudio en profundidad ${ }^{456}$, e indudablemente exigió una regulación de las relaciones entre los sexos que nunca, que yo sepa, ha merecido atención significativa en el ámbito hispánico ${ }^{457}$. Pero además, en algunos casos tempranos al menos, las promotoras parecen ignorar las al menos teóricamente rigurosas disposiciones de la independencia cisterciense. Son muy conocidos los términos en los que Estefanía Armengol organizó la fundación de Valbuena en 1153: in mea potestate sit et consilio et voluntate $m e a^{458}$. Veintitres años más tarde, la misma dama traspasaba a su hija, para la que probablemente se instituyó el establecimeinto, la decisión final sobre la orden que habría de instalarse en Carrizo, en el caso de que el Císter no deseara hacerlo, de modo que la elección quedaba in potestate prouidentia comitisse domne Marie ${ }^{459}$. Aunque generalmente no se exprese de manera tan altiva, el control ejercido sobre los monasterios femeninos y la libertad con que las damas aristocráticas se integraban en la vida monástica resultan evidentes.

El título de señora es la figura que mejor expresa la sistemática injerencia nobiliaria en los monasterios femeninos de la orden del Císter. La señora de un monasterio pertenecía a la familia de los promotores y se encargaba fundamentalmente de gestionar los asuntos materiales del cenobio, valiéndose de su privilegiada situación social y reservando los espirituales para la abadesa. Aunque aparece de forma explícita en la documentación por primera vez en el siglo XIII asociado al monasterio de Las Huelgas de Burgos, G. Baury considera, acertadamente a mi juicio, que el cargo fue también desempeñado por algunas otras damas ya desde el siglo XII ${ }^{460}$. A ellas podría añadirse probablemente el caso de Estefanía Armengol en Carrizo ${ }^{461}$ y creo que con toda probabilidad las funciones inherentes al cargo de señora reaparecen en el reino de Portugal bajo el título de domina, como se denomina

${ }^{455} \mathrm{~J}$. SORRENTINO, In houses of nuns, in houses of canons: a liturgical dimension to double monasteries. JMH, 28, 4 (December 2002), pp. 361-372.

${ }^{456}$ Algunas cuestiones generales a este propósito, y un estudio detallado del caso de Cañas en R. AlONSO, El monasterio, pp. 63-69. ejemplos sueltos.

${ }^{457}$ M.F. COELHO, Expresiones, pp. 153-155 y 198, no pasa de ofrecer unos cuantos ${ }^{458}$ J. PÉREZ-EMBid, El Císter, p. 275. Para la fecha de la donación, V. A. Álvarez; M. RECUERO, La fundación, p. 437.

459"Quod si ordini Cistelcensium non placuerit abbatiam sanctimonialum in Karrizo construire, sit in potestate prouidentia comitisse domne Marie, filie mee, faciendi ibi abbatiam sub quocumque ordine Deo seruientium sibi placuerit”. 1176, septiembre 10. M.C. CASADO, Colección, no 38. , pp. 43-45. Vid. supra, n. 267.

${ }^{460}$ Especialmente por la condesa Aldonza, en Cañas y la reina Urraca en su fundación de Vileña. G. BAURY, Les religieuses, I, pp. 191-205. También A. GARCÍA, Arquitectura, p. 72-73. ${ }^{461}$ Vid. supra. 
por ejemplo, a la infanta Sancha como directora del monasterio de Celas ${ }^{462}$, y también a sus hermanas Teresa y Mafalda en sus respectivas fundaciones ${ }^{463}$. Parece, así pues, una institución característica de la Península Ibérica que no se encuentra, hasta donde conozco, en ningún otro reino europeo.

Dominando de este modo la organización monástica, no resulta extraño advertir lo escasamente retirada que era en ocasiones la vida de estas damas supuestamente clausuradas. Sólo diez días después de su ingreso en el monasterio de Cañas, en 1171, la condesa Aldonza se encuentra en el reino de León intercambiando unas propiedades con el maestre de Santiago, desplegando una actividad que no disminuirá durante los años posteriores y que se vio sin duda incrementada por las obligaciones inherentes a la jefatura de la familia ${ }^{464}$. Las damas entran y salen de los monasterios poco menos que a su conveniencia o esa impresión, al menos, da la documentación. En ocasiones, ingresan en estas instituciones acompañando a una madre viuda, la abandonan para casarse y vuelven tras la muerte de su esposo, cuando no fundan ellas mismas un nuevo centro ${ }^{465}$. En esta amplia red monástica, es frecuente que se visiten unas a otras en sus respectivas casas ${ }^{466}$, una actividad que confiere al monacato femenino de los siglos XII y XIII un tono familiar que creíamos propio del pasado, y un cierto aire de ligereza social también. En Las Huelgas, a pesar de las sucesivas disposiciones papales ${ }^{467}$, la abadesa y otras monjas abandonaban con frecuencia los muros de la clausura para entregarse a diferentes actividades hasta que se vieron obligadas a respetar las restrictivas disposiciones del Concilio de Trento ${ }^{468}$, una situación que no parece en términos generales muy diferente de la europea ${ }^{469}$.

Las monjas y señoras pertenecientes a familias relevantes recibían también con frecuencia visitas distinguidas, y de ellas la más destacada era sin duda la del rey. Los términos en que los monarcas se refieren a estas damas

${ }^{462}$ R. AlONSO, El monasterio, p. 41.

${ }^{463}$ Vid. supra.

${ }^{464}$ G. BAURY, Les religieuses, I, pp. 195-199.

${ }^{465}$ Por ejemplo, Estefanía López, una hija de Aldonza, se encontraba en Cañas en 1174 documentada como monja. En 1207 era condesa, título que obtuvo sin duda gracias al matrimonio. María Gonzálvez abandonó su situación de monja en Carrizo para casarse con Pedro Joán, acabando sus días como abadesa de Gradefes. R. ALONSO, El monasterio, p. 40

${ }^{466} \mathrm{G}$. BAURY, Les religieuses, I, pp. 197-198. J. M. CANAL, La casa de Haro en León y Castilla de 1150 , p. 61.

${ }^{467}$ Sobre de las normas acerca de la clausura dictadas por la Santa Sede, A. BonIS, S. DEChAVANNE, M. WABONT, Introduction. En B. BARRIERE; M.-H. HENNEAU (dir.), "Cîteaux et les femmes", p. 8. J. C. BOUTON (dir.). Les moniales cisterciennes. Livre troisième. Histoire interne. Etudes sur la vie des moniales, Grignan, MCMLXXXVIII, pp. 82-83.

${ }^{468} \mathrm{~J}$.M. CALVO, Apuntes históricos sobre el célebre monasterio de Santa María La Real de Las Huelgas, Burgos, 1846, p.34.

${ }^{469}$ Vid. J.F. HAMBURGER, Art, Enclosure and the Cura Monialum: Prolegomena in the Guise of a Postcript, "Gesta", 31, 2 (1992), pp. 109-118 y, especialmente, P.D. JOHNSON, La théorie de la clôture et l'activité réelle des moniales françaises du XI au XIII $I^{e}$ siècle. En Les religieuses dans le cloitre et dans le monde des origines à nos jours. Actes du Deuxième Colloque International du C.E.R.C.O.R. Saint-Etienne, 1994, pp. 491-505. 
Son generalmente elogiosos, aunque probablemente también convencionales ${ }^{470}$. Sin embargo, en ocasiones puede que esta cordialidad manifieste contenidos de mayor alcance, quizá una acción diplomática destinada a suavizar situaciones difíciles frecuentes entre los reyes y los grandes señores ${ }^{471}$. Aunque esta tesis resulte difícil de probar, las coincidencias son a veces llamativas. En 1254 moría Diego López III, en deservicio del Rey, según recuerda la Crónica de Alfonso $\mathrm{X}^{472}$ y dejando a su familia en una comprometidísima situación ${ }^{473}$. Inmediatamente, se ponen en marcha las maquinarias regia y nobiliaria. El sabio monarca acogió en su casa al pequeño heredero de los Haro. En 1256, la reina Mencía, dama de la misma familia, prohijaba al infante Fernando, otorgando el mismo año Alfonso una espléndida donación a la abadesa Urraca de Cañas mediante un instrumento en el que se utilizan términos que sólo otra vez empleará con esa generosidad: en una concesión destinada a la infanta Berenguela, señora de Las Huelgas y hermana suya ${ }^{474}$.

Y es que, por muy competentes que parezcan estas monjas españolas, no debe olvidarse que ejercen siempre la autoridad en virtud de su pertenencia a un grupo familiar, cuyo poder parecen manifestar muchas veces las fundaciones monásticas. Así, resulta significativo el establecimiento del monasterio de Herce, una promoción de Alfonso López que siguió inmediatamente a la división de las propiedades de los Haro efectuada por Fernando III. Al quedar el monasterio familiar de Cañas en manos del primogénito Diego, Alfonso, el ascendido segundón, dispuso la creación de un nuevo cenobio femenino en sus propiedades ${ }^{475}$. El papel que desempeñaban los monasterios de monjas en la afirmación señorial y el prestigio familiar explica también probablemente la fundación de Las Huelgas de Burgos, y por qué con tanto empeño Alfonso VIII trató de que se sometieran a la casa burgalesa los establecimientos más antiguos. Promovidos por las grandes familias aristocráticas del reino: Haro, Lara, Ansúrez y Minerva, al rey no debía ocultársele hasta qué punto funcionaban como centros de poder señorial ${ }^{476}$. En este contexto adquiere especial relieve la propuesta de $\mathrm{R}$. Walker, que supone al monasterio de Las Huelgas no un trasunto de Fontevraud, como defendía la opinión tradicional, sino producto de la muy hispánica tradición del

\footnotetext{
${ }^{470}$ Por ejemplo, "Venerabiles amite mee" llama Fernando III a la reina Urraca, fundadora de Vileña. 1224, junio 7. Muñó. J. GONZÁLEZ, Reinado y diplomas de Fernando III. II. Diplomas 1217-1232, Cordoba, 1983, n ${ }^{\circ}$ 194, pp. 234-236.

${ }^{471}$ G. BAURY, Les religieuses, I, p. 407.

${ }^{472}$ Crónicas de los reyes de Castilla. Tomo I. Madrid, 1953, p. 26.

${ }^{473}$ Un panorama de estos acontecimientos en J.F. O'CALlAGHAN, El Rey Sabio. El reinado de Alfonso X de Castilla. Sevilla, 1996, pp. 107-108.

${ }^{474}$ Un análisis de estos problemas en R. AlOnSO, El monasterio, pp. 34-35, 58-59.

${ }^{475}$ J. DE LEZA, Los López, p. 41. G. BAURY, Les religieuses, I, pp. 93 y 206-207.

${ }^{476}$ J. PÉREZ-EMBID, El Císter femenino en Castilla y León. Fundación, pp. 1086-1088. G. BAURY, Les religieuses, I, p. 240. R. AlONSO, El monasterio, pp. 24-25.
} 
Infantado $^{477}$, una poderosa institución reservada a las infantas célibes, expresión por tanto de la extraordinaria influencia alcanzada por las mujeres nobles en el reino castellanoleonés.

\section{FINAL}

A estas alturas de la exposición, espero que el lector habrá advertido cual es mi propuesta fundamental: la orden del Císter se habría difundido en Castilla y León a través de estas tupidas redes aristocráticas. Para terminar el intento de demostración, y estos son, me temo, mis últimos argumentos, sólo me restan unas breves consideraciones finales.

$\mathrm{Si}$ admitimos que Sobrado fue el primer monasterio cisterciense español, deberemos suponer también que fueron los Traba los introductores de la orden en la Península Ibérica. Creo que se puede ir algo más lejos: cuando en otras familias, más tarde, aparece la preferencia bernarda, esta nueva devoción suele coincidir con un enlace matrimonial con un miembro femenino del grupo gallego. Se comentó hace unas páginas lo llamativo de las fundaciones cistercienses de los Ansúrez y Armengol, más próximamente interesados, en teoría, por la reforma premostratense vinculada a su familia. El primer establecimiento cisterciense del grupo, Valbuena (1153), estuvo precedido por el matrimonio, celebrado en 1142, el año de la fundación de Sobrado, por cierto, de María Fernández de Traba y Ponce de Cabrera, primo de Estefanía Armengol.

La unión de Aldonza González, una Traba, con Lope Díaz, inició igualmente una sucesión de fundaciones, en este caso exclusivamente femeninas, que pusieron en manos de los Haro hasta seis monasterios cistercienses. El más antiguo establecimiento favorecido por la casa de Lara, Perales (1160), fue promovido por Nuño Pérez en colaboración con su mujer, Teresa Fernández, una hija de los fundadores de Sobrado.

Todos estos indicios permiten suponer que, al igual que en el cuidado de los enterramientos familiares ${ }^{478}$, las mujeres desempeñaban también un papel importante en la transmisión de las nuevas devociones. Esta propuesta, que en un estudio general como éste no puede más que enunciarse, debería comprobarse realizando estudios detallados y, especialmente, mediante la

\footnotetext{
${ }^{477}$ R. WALKER, Leonor of England, Plantagenet queen of King Alfonso VIII of Castile, and her foundation of the Cistercian abbey of Las Huelgas. In imitation of Fontevraud?. JMH, 31, 4 (December 2005), pp. 346-368. Para la importancia política y espiritual del Infantado: $P$ HENRIET. "Deo votas". L'Infantado et la fonction des infantes dans la Castille et le León des $X^{e}$ XIII $e^{2}$ siecles. P. HENRIET, A.-M. LEGRAS (textes réunis par) "Au cloître et dans le monde. Femmes, hommes et sociétés (IX ${ }^{\mathrm{e}}-\mathrm{XV}^{\mathrm{e}}$ siècle). Mélanges en l'honneur de Paulette l'HermiteLeclecq". Paris, 2000, p. 189-203.

${ }^{478}$ Para el papel desempeñado por las mujeres españolas en las decisiones funerarias, la conservación de la memoria y el aumento del prestigio familiar, R. WALKER, Images of royal and aristocratic burial in northern Spain, c. 950-c. 1250. En E. VAN HOUTS (ed.), "Medieval memories. Men, Women and the Past 700-1300”. S/1, 2001, pp. 150-172.
} 
renovación de las perspectivas de análisis. En estas páginas ya se ha ido mucho más lejos de lo que fuera la intención inicial.

Fecha de recepción del artículo: abril 2007.

Fecha de aceptación y versión final: junio 2007. 


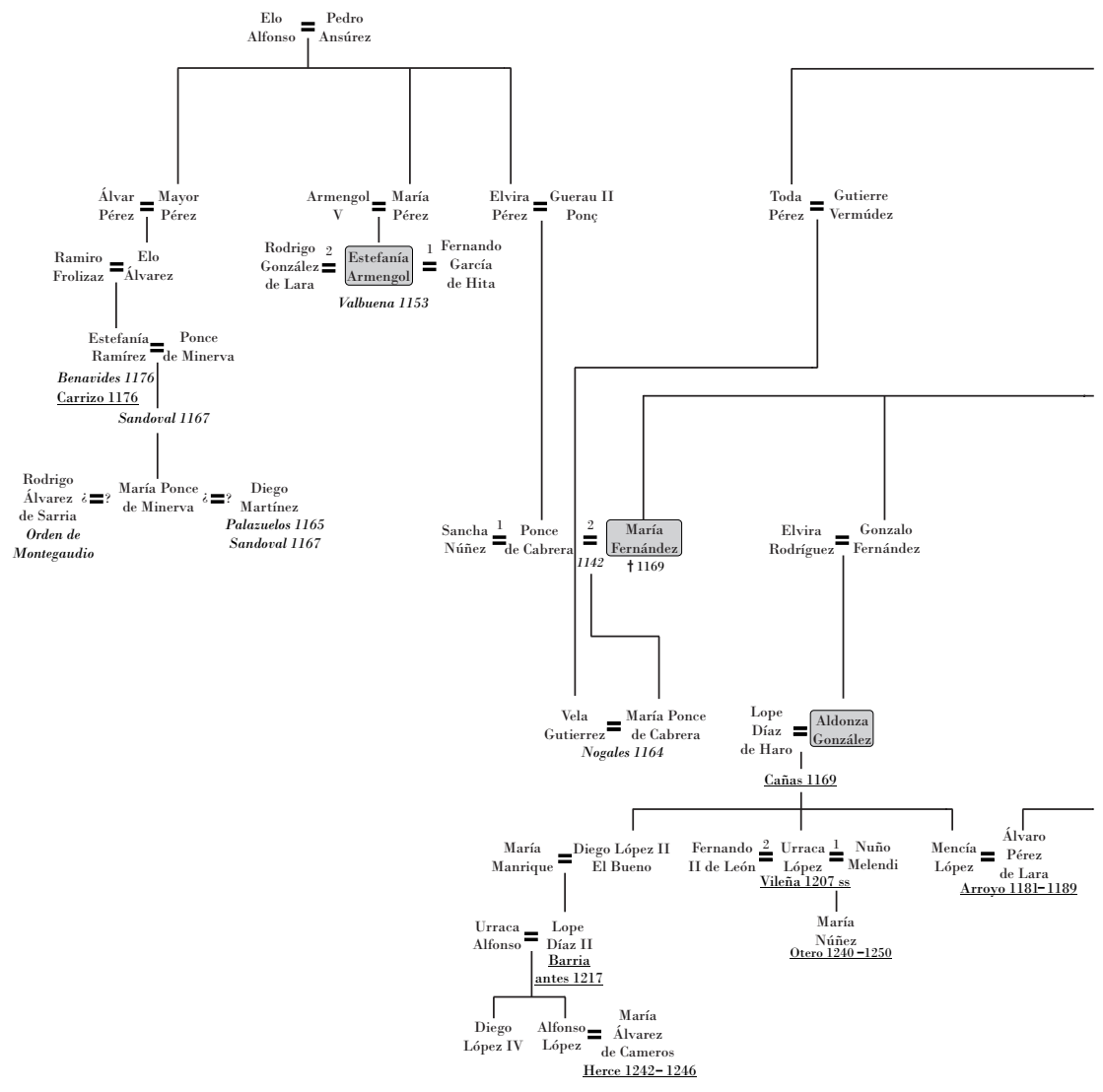




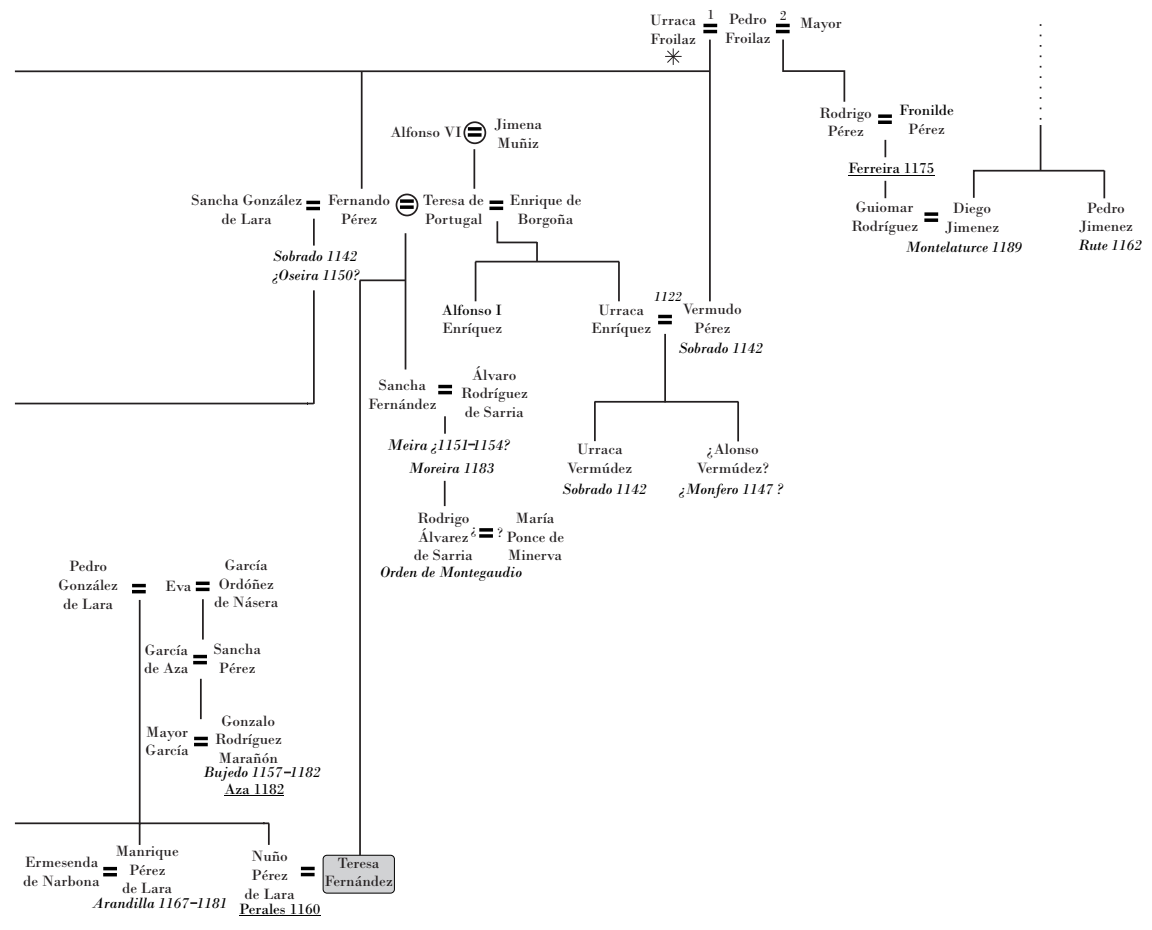

FUNDACIONES CISTERCIENSES CASTELLANO-LEONESAS PROMOVIDAS POR LAS FAMILIAS ARISTÓCRATAS

Fundaciones masculinas

Fundaciones femeninas

$\Theta$ Uniones ilegítimas

* Heredera de Sobrado 